\title{
AN ANALYSIS OF THE EFFECTS OF SELECTION
}

Br A. H. STURTEVANT

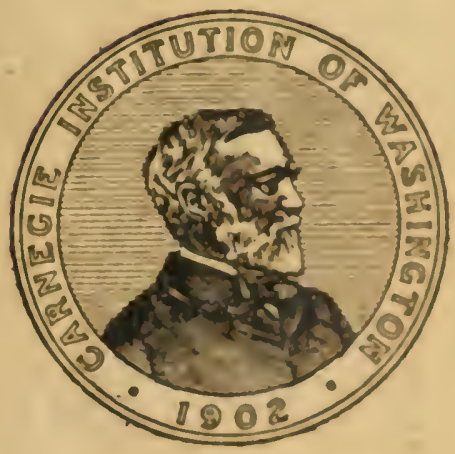

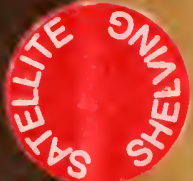

Publighfon by the Carnegie Ingtitution of Wasmisotos

WasUnGton, 1918

QH371

58 


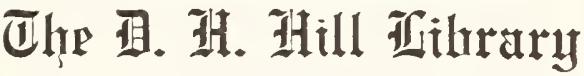

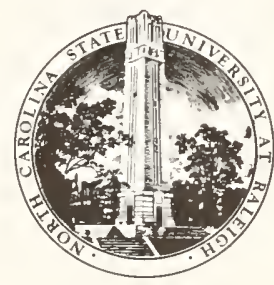

Ziorth Caralina State Zlniurraity 
North Carenta State Library

Raleigh

\section{AN ANALYSIS OF THE EFFECTS OF SELECTION}

By A. H. STURTEVANT

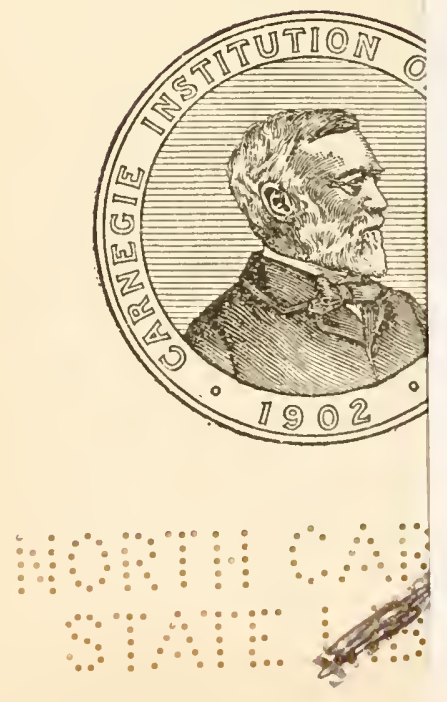

THIS BOOK IS DUE ON THE DATE INDICATED BELOW AND IS SUBJECT TO AN OVERDUE FINE AS POSTED AT THE CIRCULATION DESK.

Published by the Carnegie Instit

WASHINGTON, 19

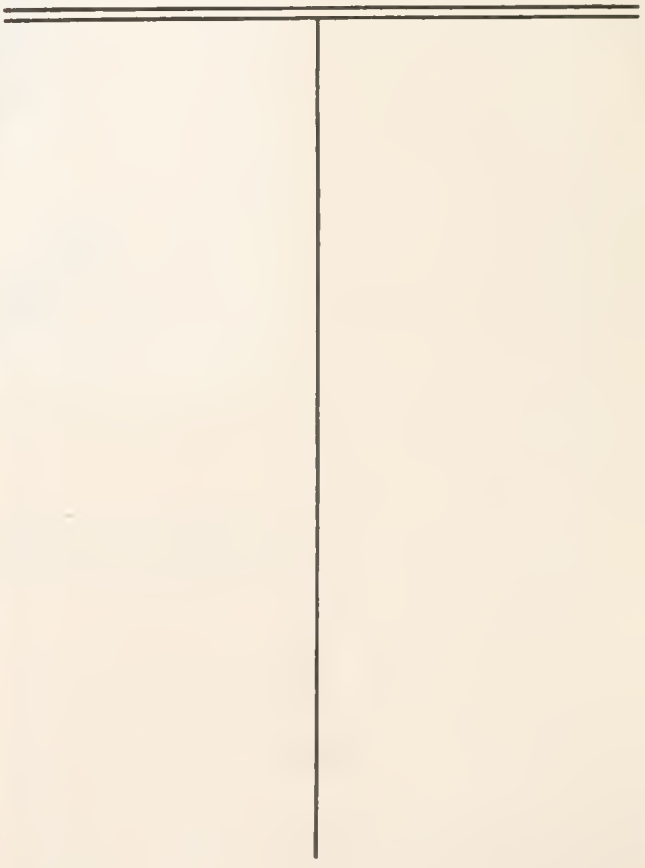




\section{CARNEGIE INSTITUTION OF WASHINGTON}

Publicatron No. 264 

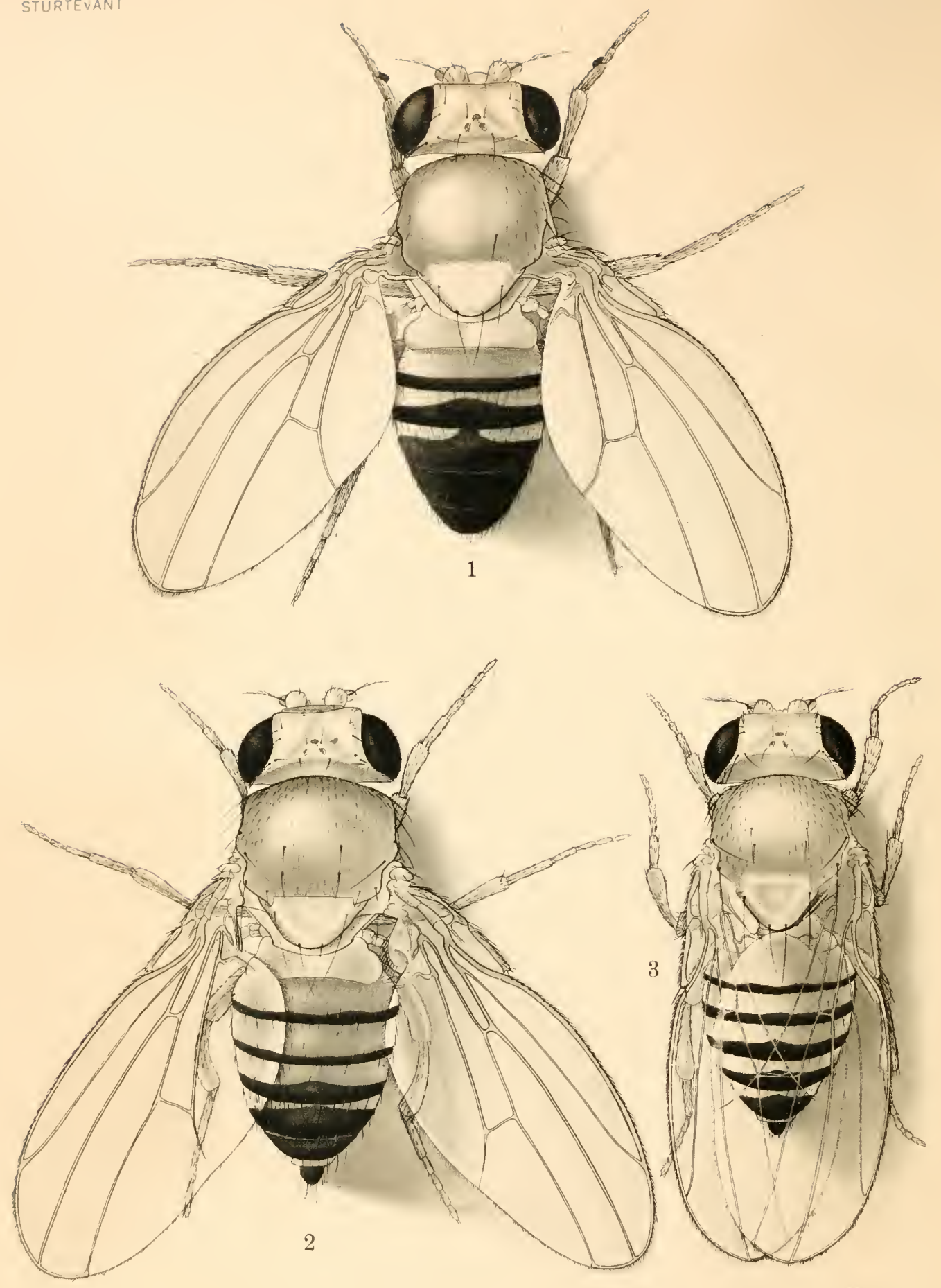

1. Dichaet male (5-bristled) 2. Extended female. 3. Wild-type female. (Drawings by Miss E. M. Wallace.) 


\section{ANANALYSIS OF THE EFFECTS OF SELECTIOY. ${ }^{2}$}

\section{INTRODUCTORY SUMMARY.}

The present paper describes a series of experiments aimed at determining the causes of the variability in bristle number observed in Dichæt, a mutant race of Drosophila melanogaster (ampelophila). These experiments are discussed under several headings, as follows:

(a) Selection of plus and of minus variants was carried out. Both plus and minus lines were obtained and were used in the further experiments.

(b) A plus line and a minus line were crossed, and an increase in variability was observed in $\mathrm{F}_{2}$.

(c) Linkage tests were made, and by this means it was demonstrated that modifying genes were present in the selected lines.

(d) Evidence against the hypothesis of contamination of allelomorphs was obtained.

(e) This evidence, and that obtained by other investigators, is then utilized in a general discussion of the selection problem, and of the hypothesis of contamination of genes. The conclusions are drawn that selection is usually effective only in isolating genetic differences already present; and that genes are relatively stable, not being contaminated in heterozygotes, and mutating only very rarely.

\section{DICHÆT.}

The mutant character known as Dichxt was discovered by Dr. C. B. Bridges, July 3, 1915. In an experiment involving the sexlinked characters sable, forked, and cleft there appeared a single female that had wings extended and bent backwards near the base, like those of the mutant bent (Muller, 1914b). In addition it was observed that this female had only 2 dorso-central bristles, instead of the 4 usually present. When mated to a male having the mutant character eyeless, this female produced 48 normal offspring and 46 "Dichæt," thus showing the character to be dominant.

Bridges's unpublished data show that the Dichret gene is in the third chromosome, approximately 5 units to the left of pink.

The data published by Muller (1916) give the locus as 9.7 from sepia (the locus farthest to the left of those as yet discovered), and 11.0 from spineless, on the right. My own (unpublished) data give:

Sepia Dichæt, $\frac{204}{1369}=14.9$ p. ct. $\quad$ Dichæt spincless, $\frac{122}{931}=13.1$ p.ct.

\footnotetext{
1 I am indebted to Mr. J. W. Gowen for much advice and assistance in ennnection with the statistical treatment of the present problem. He has done a part of the actual calculations, but is not responsible for any arithmetical slips, as I have myself done all the checking.
} 
The averages, roughly weighted according to number of individuals, are: sepia Dichæt, 13; Dichæt spineless, 12. This agrees with the data of Bridges on the position of Dichæt with reference to pink, since that locus is about 8 to the left of spineless.

Bridges also found that homozygous Dichæts are not produced. The gene, like that of the yellow mouse, acts as a lethal when homozygous. The result is that when Dichæts are mated together they produce two heterozygous Dichæts to one not-Dichæt. This discovery has been verified by the experiments described in this paper, and by other experiments carried out by Muller and by the author.

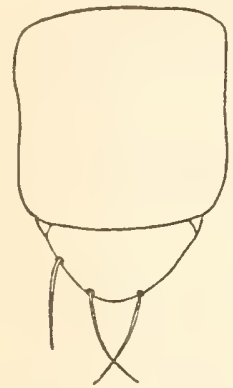

Figs. 1 and 2.-Two types of bristle distribution in Dichæts-a "3" and a "7." Small post-alars are present in fig. 2. These are never counted in the totals.
TABLE 1.

\begin{tabular}{|c|c|c|c|c|c|}
\hline \multirow{2}{*}{$\begin{array}{c}\text { Culture } \\
\text { No. }\end{array}$} & \multicolumn{4}{|c|}{ No. of bristles. } & \multirow{2}{*}{ Total. } \\
\hline & 3 & 4 & 5 & 6 & \\
\hline \multirow{6}{*}{$\begin{array}{r}881 \\
882 \\
883 \\
900 \\
2715\end{array}$} & & 9 & 20 & 27 & 56 \\
\hline & 1 & 23 & 29 & 30 & 83 \\
\hline & .. & 9 & 11 & 11 & 31 \\
\hline & .. & 32 & 22 & 13 & 67 \\
\hline & .. & 7 & 15 & 3 & 25 \\
\hline & 1 & 80 & 97 & 84 & 262 \\
\hline
\end{tabular}

2 and 7 bristles have also been observed in unselected stocks.

As shown in plate 1, fig. 1, the wings of Dichæt flies are held out from the body and are bent back near the base. The number of dorsocentral bristles (on the dorsum of the thorax) on the original female was 2 instead of 4 , as is usually the case in the normal fly (plate 1, figs. 1 and 3). This has since been found to be a variable character.

The number of dorso-centrals varies from 0 to 4 , and sometimes one or more of the scutellars may be missing. In addition, the anterior post-alars above and just behind the wing-base are reduced or absent. Plate 1, figure 1, and text-figures 1 and 2 show some common types. The work reported in this paper has consisted in selecting for a high and for a low total of scutellar and dorso-central bristles. Counts from five unselected cultures gave the results as shown in table 1.

The normal flies occasionally show variations in bristle number, but these are much rarer than in the case of Dichæt. MacDowell (1915) has given some data on the frequency of these variations, and has also reported on very extensive selection experiments with them (1915, 1917). These experiments will be referred to below.

I have made bristle counts on a few unselected not-Dichæt stocks, with the results shown in table 2.

The normal flies have 8 dorso-central and scutellar bristles in most cases, while the Dichæts range from 1 to 8. But the 8-bristled Dichæts are still distinguishable from normals, even when their wings are not 
unfolded enough so that they can be separated on that basis. This is because the anterior pair of dorso-centrals never, so far as I have observed, becomes as large as the corresponding pair in normal flies. The anterior post-alars are also reduced in 8-bristled Dichæts. This

TABLE 2.

\begin{tabular}{|c|c|c|c|c|c|c|c|c|c|c|c|}
\hline \multirow{2}{*}{ Stock. } & \multicolumn{2}{|c|}{6} & \multicolumn{2}{|c|}{7} & \multicolumn{2}{|c|}{8} & \multicolumn{2}{|c|}{9} & \multicolumn{2}{|c|}{10} & \multirow{2}{*}{ Total. } \\
\hline & 우 & $\sigma^{7}$ & ㅇ & $\sigma^{7}$ & q & $0^{x}$ & q & $\sigma^{7}$ & 우 & $\sigma^{7}$ & \\
\hline Wild: & & & & & & & & & & & \\
\hline Falmouth, Massachusetts. & 0 & 0 & 0 & 1 & 186 & 118 & 11 & 2 & 0 & 0 & 318 \\
\hline Berkeley, California...... & 0 & 0 & 0 & 0 & 95 & 104 & 0 & 0 & 0 & 0 & 199 \\
\hline Mitchell, South Dakota... & 0 & 0 & 0 & 0 & 226 & 213 & 4 & 1 & 0 & 0 & 444 \\
\hline Amity, Oregon............ & 0 & 0 & 0 & 0 & 59 & 51 & 1 & 1 & 0 & 0 & 112 \\
\hline Sydney, Australia........ & 0 & 0 & 0 & 0 & 16 & 21 & 0 & 1 & 0 & 0 & 38 \\
\hline Pink band $\ldots \ldots \ldots \ldots \ldots \ldots$ & 0 & 0 & 1 & 5 & 103 & 99 & 1 & 0 & 0 & 0 & 209 \\
\hline Black................... & 0 & 0 & 0 & 0 & 26 & 38 & 0 & 0 & 0 & 0 & 64 \\
\hline Ebony $\ldots \ldots \ldots \ldots \ldots \ldots$ & 0 & 0 & 0 & 0 & 80 & 92 & 0 & 0 & 0 & 0 & 172 \\
\hline Blistered................ & 0 & 0 & 0 & 0 & 114 & 67 & 0 & 0 & 0 & 0 & 181 \\
\hline White.................. & 0 & 0 & 0 & 0 & 74 & 77 & 2 & 0 & 0 & 0 & 153 \\
\hline
\end{tabular}

separability is a matter of some importance, since, because of the lethal effect of Dichæt, any Dichæt culture may produce normal flies. However, the spread wings can be and are used for the separation in all but the rather rare instances of failure to expand properly.

\section{SEXUAL DIMORPHISM.}

Calculations show that there is a slight but significant sexual dimorphism in bristle number in the Dichrt races. Random selection of plus and of minus selected cultures gave the totals shown in table 3.

TABLE 3 .

\begin{tabular}{|c|c|c|c|c|c|c|c|c|c|}
\hline & \multicolumn{8}{|c|}{ Bristle number. } & \multirow{2}{*}{ Total. } \\
\hline & 1 & 2 & 3 & 4 & 5 & 6 & 7 & 8 & \\
\hline Plus & & & 4 & 490 & 668 & 1,702 & 81 & 6 & 2,951 \\
\hline Plus $\sigma^{7}$. & & 3 & 25 & 436 & 684 & 1,527 & 53 & 8 & 2,736 \\
\hline Minus $o$. & 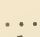 & 5 & 17 & 1,517 & 712 & 424 & 7 & . & 2,682 \\
\hline Minus $\sigma^{7}$. & 1 & 39 & 177 & 1,190 & 615 & 332 & 2 & & 2,356 \\
\hline
\end{tabular}

These distributions give the statistical constants shown in table 4 . The first three columns show that there is a slight difference in the means, the females being higher in both cases. In the case of the plus series the difference is doubtfully significant; in the minus series it is larger and certainly significant. The last column gives the chance 
that differences as great as those observed between the two distributions are due to random sampling. These values were obtained by Pearson's $\chi^{2}$ method (Pearson, 1911). This column makes it quite certain that there is a significant sexual dimorphism in both series, and also brings out again the fact that the dimorphism is greater in the minus series.

TABLE 4.

\begin{tabular}{|c|c|c|c|c|}
\hline & o Mean. & $\sigma^{7}$ Mean. & Difference. & $\mathrm{P}$ \\
\hline Plus.... & $\begin{array}{r}5.468 \pm 0.010 \\
4.583 \pm .010\end{array}$ & $\begin{array}{r}5.428 \pm 0.010 \\
4.436 \pm .012\end{array}$ & $\begin{array}{r}0.041 \pm 0.014 \\
.147 \pm .016\end{array}$ & $\begin{array}{r}0.0001 \\
.0000000+\end{array}$ \\
\hline
\end{tabular}

Because of the information given by this table it has seemed desirable to present the data for males and females separately. This has been done in the Appendix; but since the dimorphism is slight, the data have been lumped in the statistical treatment given in the body of the paper. The data in the Appendix make it possible to recalculate the constants separately if it should seem desirable to do so.

\section{EFFECTS OF ENVIRONMENT.}

In any selection experiment it is obviously very important to have some information regarding the influence of environmental conditions on the variable character used. If the observed variations in the character are largely due to environmental causes, it should be very difficult to accomplish much by selection; but if the environment plays little part in causing variability, selection should be very effective in isolating different types, and on the multiple-factor view variability should show a marked decrease after a few generations of inbreeding.

In the case of Dichæt, it has been observed that as cultures grow older the flies frequently have fewer bristles. In such cultures it is usually observed that the later flies are also smaller and that the food conditions in the bottle have become unfavorable. It is, therefore, essential in such experiments that conditions be made as nearly uniform as practicable.

The data in table 5 show that under ordinary conditions there is considerable environmental effect. Eight pairs from the regular series were transferred to second bottles, after staying the usual period in the first one. Offspring were thus obtained with identical pedigrees and differing only in that they were reared in separate bottles. No attempt has been made to make conditions different in the two bottles, which constitute a random sample of the conditions under which the experiments were carried out. Table 5 shows the results obtained. (The actual data are in the Appendix; the first three columns of the 
table will enable the reader to find them.) The last three columns give the results of an application of the $\chi^{2}$ test to the data. The last column, headed $\mathrm{P}$, gives the chance (1.0 representing certainty) that deviations from identity as great as those observed could have resulted from random sampling. It follows that in at least three cases (the fifth, sixth, and seventh) the results given by the two broods were significantly different.

TABle 5.-First and Second Broods from Same Parents.

\begin{tabular}{|c|c|c|c|c|c|c|}
\hline \multicolumn{2}{|c|}{ Culture Nos. } & \multirow{2}{*}{ Series. } & \multirow{2}{*}{$\begin{array}{c}\text { Gener- } \\
\text { ations } \\
\text { mother } \\
\text { inbred. }\end{array}$} & \multirow{2}{*}{$\chi^{2}$} & \multirow{2}{*}{$n^{\prime}$} & \multirow{2}{*}{$\mathbf{P}$} \\
\hline $\begin{array}{l}\text { First } \\
\text { brood. }\end{array}$ & $\begin{array}{l}\text { Second } \\
\text { brood. }\end{array}$ & & & & & \\
\hline 1,907 & 1,996 & $1331 \ldots \ldots \ldots \ldots$ & 4 & 3.74 & 3 & 0.16 \\
\hline 1,908 & 1,997 & 1002 rev.......... & 6 & 5.60 & 5 & .23 \\
\hline 1,912 & 1,998 & $1002 \ldots \ldots \ldots \ldots$ & 7 & 2.10 & 4 & .55 \\
\hline 1,924 & 1,999 & $1002 \ldots$ & 7 & 6.05 & 5 & .19 \\
\hline 2,074 & 2,140 & $900 \ldots$ & 9 & 22.09 & 4 & .0001 \\
\hline 2,078 & 2,141 & Test of crossbr. plus. & 11 & 16.81 & 4 & .001 \\
\hline 2,087 & 2,142 & $864 \ldots \ldots \ldots \ldots$ & 11 & 19.80 & 5 & .0005 \\
\hline 2,475 & 2,518 & Test of 1002. & ${ }^{1} 18$ & 5.22 & 3 & .075 \\
\hline
\end{tabular}

${ }^{1} \mathrm{~F}_{16}$ and $\mathrm{F}_{17}$ were mass cultures in this case.

There is one possible source of error in these data: It has been shown by Bridges (1915) that the amount of crossing over in the second chromosome of Drosophila varies with the age of the female. My own unpublished data show that this is also true for the third chromosome. In the present case, if the female parents of the flies observed were heterozygous for many modifying factors, such a change in linkage might result in the production of genetically different first and second broods. However, the female parents in these cultures were in every case from at least four generations of brothersister inbreeding (see table 5 , column 4$)^{1}$ and in the significant cases for 9 and 11 generations. It is therefore very unlikely that they were heterozygous for many modifying factors. The two broods from these females must, then, be of the same genetic constitution, and the differences between them can only be due to enrironmental causes. It follows that in the experiments recorded below a significant part of the variability is not genetic, but environmental.

\section{METHODS.}

With very few exceptions, the flies recorded in this paper were bred from pairs, and in pint milk bottles. The food used was ripe uncooked banana, fermented in a stock yeast-culture for from 12 to 48.

\footnotetext{
${ }^{1}$ Three eases in which the female parents were hybrids have been discarded (see 2091-2143, 3064-3116, 3066-3118 pairs in Appendix).
} 
hours (usually about 24 hours). Paper toweling was added to absorb surplus moisture.

The experiments were begun in New York City in February 1916, and were carried on there until the middle of June, when the material was moved to Woods Hole, Massachusetts, and continued there until the end of September. All these flies were kept at room temperature. The work was resumed in November, in New York, and continued until the middle of May 1917. During these last six months the flies were reared in a heated case that was regulated by a thermostat, so that the minimum temperature was about $24^{\circ}$, the maximum being about $26^{\circ}$, except when room temperature went a few degrees higher, as occasionally happened. It is to be noted that the constant-temperature series run more evenly (see especially 1002 line), thus suggesting that temperature influences bristle number.

In order that the data presented in the Appendix may be correlated with this information, if it seems desirable to do so, the following table is presented. Each culture received a serial number at the time the parents were mated, and these numbers run consecutively throughout all the author's recent experiments (on other problems as well as selection). These serial numbers are recorded in the Appendix. Therefore, it is possible to fix approximately the date on which a culture was made up, if we know the date on which a culture with a similar number was made up. The dates of all cultures are noted on the record sheets, but it has seemed hardly necessary to present more than the following "landmarks."

TABLE 6.

\begin{tabular}{|r|c||c|c||c|c|}
\hline Culture. & Date. & Culture. & Date. & Culture. & Date. \\
\cline { 2 - 3 } 884 & Feb. 3, 1916 & 1507 & June 7, 1916 & 2389 & Sept. 16, 1916 \\
1006 & Mar. 24, 1916 & 1617 & June 23, 1916 & 2423 & Nov. 18, 1916 \\
1100 & Apr. 16, 1916 & 1830 & July 14, 1916 & 2601 & Jan. 13, 1917 \\
1150 & Apr. 22, 1916 & 2000 & Aug. 1, 1916 & 2950 & Mar. 17, 1917 \\
1301 & May 15, 1916 & 2250 & Aug. 28, 1916 & 3078 & Apr. 15, 1917 \\
1401 & May 28, 1916 & & & & \\
\hline
\end{tabular}

\section{SELECTION.}

If the variations observed in the Dichæt character are due to modification of the Dichæt gene itself, selection should be as effective in inbred stocks as in any other kinds. If multiple factors are responsible for the variations, the method of breeding should affect the result. If a stock is closely inbred while being selected, it will soon become fairly uniform, so that selection should be effective for only a comparatively short time. But if a strain is subjected to some crossing it will become uniform more slowly, so that selection should be effective 
longer. Moreover, there is a chance of combining more of the desired modifiers in the same individual when crossing is done, so that this method might produce more extreme results than the inbreeding method. However, each time a cross is made some of what has been gained may be hidden by dominants in the other stock; therefore progress might sometimes be slower.

Accordingly, in these experiments parallel series have been carried on. In one set selection has been accompanied by continuous brothersister matings; in the other, frequent crosses have been made between individuals more or less closely related. The same method has been followed in both the plus and the minus selected lines. The four series will be considered in order: (1) inbred plus; (2) crossbred plus; (3) inbred minus; (4) crossbred minus.

\section{INBRED PLUS SERIES.}

Two main lines of this series have been carried on. A few cultures have been made from other sources, but none of these are sufficiently extensive so that we need follow their histories here.

\section{Line.}

Culture 864 , from which this line arose, was produced by a female of the constitution $\frac{D^{\prime} r_{o}}{p^{p} s_{s} k e^{s} r_{o}}$ from culture 847, and two males from the sepia, spineless, kidney, sooty, rough stock; 847 was the result of mating four peach, spineless, kidney, sooty, rough males from stock to a female of the constitution $\frac{D^{\prime} r_{o}}{p^{p} s_{s} e}$. This female was descended from the Dichæt, ebony, peach, spineless, kidney, sooty, rough, and other stocks. Her pedigree is not now traceable in detail.

At the time culture 864 was counted, the scutellar bristles were not observed. The dorsocentral bristles were recorded on 30 flies, as shown in table 7 .

TABle 7.

\begin{tabular}{|c|c|}
\hline $\begin{array}{c}\text { Dorso- } \\
\text { centrals. }\end{array}$ & Off spring. \\
\hline 0 & 12 \\
1 & 8 \\
2 & 9 \\
3 & 1 \\
Total.... & $\frac{1}{30}$ \\
\hline
\end{tabular}

The 3 (almost certainly a 7 , according to the system later adopted), a male, was mated to a 2 (6) female to produce culture 893 . For the details of the remainder of the pedigree see Appendix.

In the accompanying tables and curves the offspring of culture 893, above, are considered $F_{1}$. Table $\delta$ gives the data for this line summarized by generations. In this and the following tables, $n$ is the number of individuals in the generation, $M$ is the mean bristlenumber of the generation, $\sigma$ is the standard deviation, $r$ is the parentoffspring correlation, and is recorded in the generation to which the offspring belong. Diff. M. is the mean bristle-number of the offspring minus the mean bristle-number of their parents, weighted 
according to number of offspring, and is also recorded in the offspring generation. In the calculation of $r$, the parental grades are taken as the average grades of the two parents. When $r$ is not given, it is not capable of calculation, for the reason that all parental pairs in that generation were of the same average grade. The correlation coefficients given here are of doubtful significance, though many of them are several times their probable errors. These probable errors, like

TABLE 8.-S64, Inbred Plus Line.

\begin{tabular}{|c|c|c|c|c|c|}
\hline Generation. & $n$ & $M I$ & $\sigma$ & $r$ & Diff. M. \\
\hline $\begin{array}{l}F_{1} \ldots \ldots \\
F_{2} \ldots \ldots \\
F_{3} \ldots \ldots \\
F_{4} \ldots \ldots \\
F_{5} \ldots \ldots \\
F_{6} \ldots \ldots \\
F_{7} \ldots \ldots \\
F_{8} \ldots \ldots \\
F_{9} \ldots \ldots \\
F_{10} \ldots \ldots \\
F_{11} \ldots \ldots \\
F_{12} \ldots \ldots \\
F_{13} \ldots \ldots \\
F_{14} \ldots \ldots\end{array}$ & $\begin{array}{r}113 \\
121 \\
73 \\
260 \\
149 \\
120 \\
510 \\
461 \\
154 \\
159 \\
232 \\
624 \\
353 \\
175 \\
3,50-1\end{array}$ & $\begin{array}{l}5.672 \pm 0.048 \\
5.331 \pm .049 \\
5.822 \pm .031 \\
4.904 \pm .036 \\
5.228 \pm .043 \\
5.450 \pm .044 \\
5.190 \pm .025 \\
5.475 \pm .023 \\
5.643 \pm .034 \\
4.956 \pm .051 \\
5.224 \pm .039 \\
5.272 \pm .025 \\
5.787 \pm .024 \\
6.080 \pm .026\end{array}$ & $\begin{array}{c}0.762 \pm 0.034 \\
.804 \pm .035 \\
.396 \pm .022 \\
.868 \pm .026 \\
.771 \pm .030 \\
.705 \pm .031 \\
.835 \pm .018 \\
.738 \pm .016 \\
.621 \pm .024 \\
.960 \pm .036 \\
.867 \pm .027 \\
.937 \pm .018 \\
.667 \pm .017 \\
.506 \pm .018\end{array}$ & 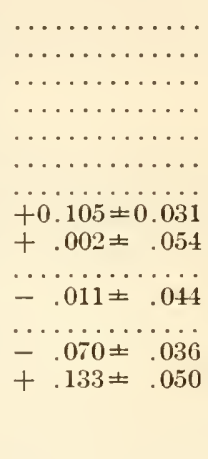 & $\begin{array}{l}-0.828 \\
-1.179 \\
-. .178 \\
-1.016 \\
-. .772 \\
-.550 \\
-. .810 \\
-.514 \\
-. .458 \\
-1.044 \\
-.901 \\
-. .728 \\
-. .762 \\
-. .300\end{array}$ \\
\hline \multicolumn{6}{|c|}{ Reversed Selection. } \\
\hline $\begin{array}{l}\mathrm{F}_{11} \ldots \\
\mathrm{F}_{12} \ldots \\
\mathrm{F}_{13} \ldots\end{array}$ & $\begin{array}{r}33 \\
49 \\
62 \\
144\end{array}$ & $\begin{array}{l}5.152 \pm 0.102 \\
5.327 \pm .092 \\
5.710 \pm .052\end{array}$ & $\begin{array}{c}0.869 \pm 0.072 \\
.956 \pm .065 \\
.606 \pm .037\end{array}$ & 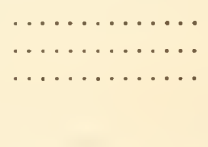 & $\begin{array}{l}+0.652 \\
+1.329 \\
+1.710\end{array}$ \\
\hline
\end{tabular}

others of their kind, are intended only to give the magnitude of the error likely to arise from the fact that one is dealing with a sample of limited size-the error of random sampling. But in the present case the correlation coefficient is intended to measure the similarity between the somatic appearance and the genetic possibilities of the parent individuals. It is known that this similarity does not amount to identity, and that it may be modified in individual cases bv environmental causes. Since in any given case we are dealing with a rather small number of parent individuals, but a large number of offspring individuals, the selection of one or two parents whose somatic appearance differs widely from their genetic possibility will throw the resulting correlation coefficient far off; but the large number. of offspring will keep the probable error down. If, instead of entering each offspring individual in the correlation table separately, we enter only the mean grade of the offspring of each parent pair, we get what is perhaps a more reasonable probable error. But this method fails 
to weight the results from different parents according to the number (and therefore reliability) of their offspring. In the present case, also, it gives an extremely large probable crror, and probably gives a less accurate value for the coefficient itself. The usual method has accordingly been followed, but little reliance is to be placed on the biological significance of the results obtained. Hence in the following discussion the correlation coefficients will be largely ignored.

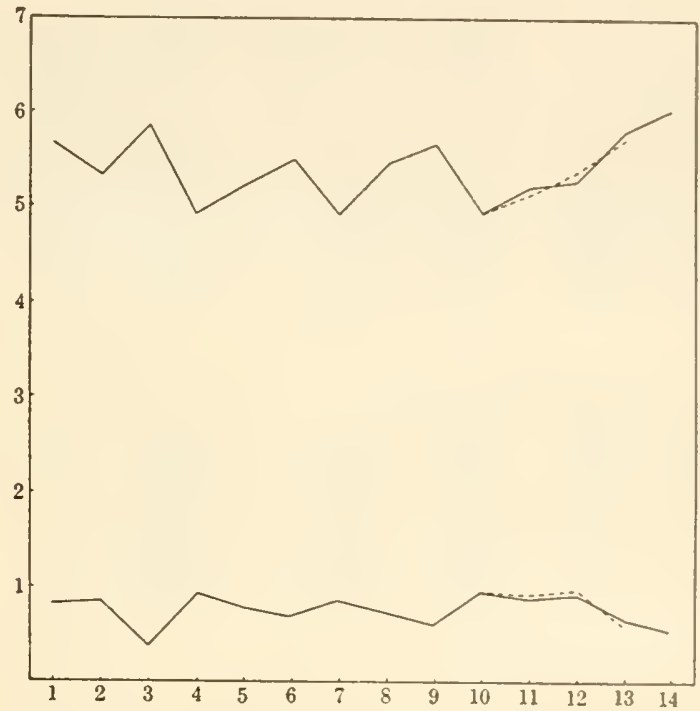

FIG. 3.-Means and standard deviations for $\$ 64$ inbred plus line. The generation number is given on the abscissa; bristle number on the ordinate. The dotted lines represent reverse selection.

The values for $M$ and $\sigma$ in the $\$ 64$ line are plotted in figure 3 . Selection has apparently affected this line hardly at all. This is perhaps because in the early generations so few individuals were bred from. Reversed selection (dotted line in curve) was ineffective in the eleventh to thirteenth generations, thus indicating again that at that stage at least the line was not capable of modification through selection. ${ }^{1}$

\section{LINE.}

The second inbred plus line is descended from culture 1002. The female in this culture was of the constitution $\frac{D^{\prime}}{s_{e} s_{s} k e^{2} r_{o}}$ and the four males were from the peach, spineless, kidney, sooty, rough stock.

'The fact that the signs of the differences between the neans are reversed when selection is reversed is due simply to the faet that the parents seleeted are now below the mean of the line. instead of above it. The difference between the means, like the correlation coefficient, is of slight signifieance when the number of parent individuals is as small as in these experiments, and for the same reasons. 
The female was from culture 916 , which contained a sepia, spineless, kidney, sooty, rough male, and a female $\frac{D^{\prime}}{s_{e} r_{o}}$. This female was the offspring of a Dichæt from stock and of a fly from culture 869 (q. $v$. below, in the pedigrees of 900 and crossbred minus lines). No bristle counts are available from culture 1002 , except those of the pair $(6 \times 6)$ selected to produce culture 1072 , the $F_{1}$ of this line.

After this line had been inbred and selected for 11 generations, a pair of 7-bristled flies were taken from 2389, and their descendants were bred in mass cultures, unselected Dichæts being mated together, for about 2 generations. The line was then re-established by selecting pairs from this stock and was inbred for 8 generations more.

The data and curves for this line are given in table 9 and figure 4.

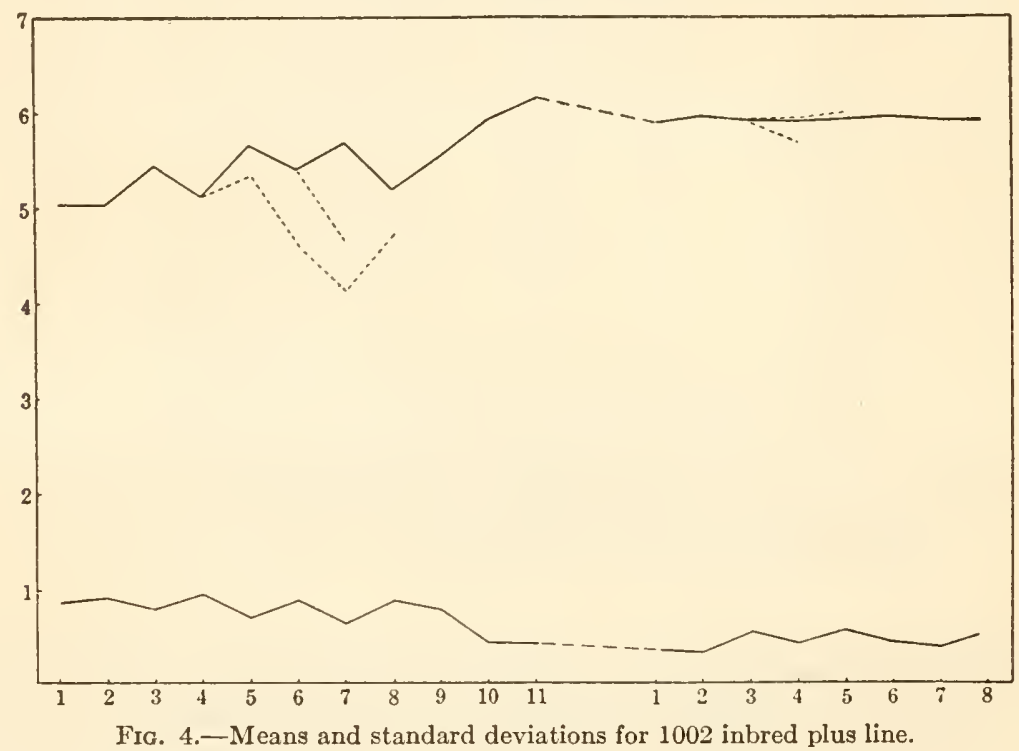

Here selection was perhaps effective for a few generations. Reference to the Appendix will indicate that this effectiveness was probably due in large part to the gradual elimination of the descendants of one of the $\mathrm{F}_{2}$ pairs (1158), which were on the average of slightly lower grade than those of the other $\mathrm{F}_{2}$ pair (1150). It is to be observed that both of the apparently successful reversed-selection series were made with descendants of the former branch of the family.

The eighth to eleventh generations of this line and the contemporary eleventh to fourteenth of the 864 line gave very similar results as to the means and standard deviations. We shall see below (p. 19) reason for believing that the two lines were of very similar constitution at this period. The gradual rise of the means and fall of the standard deviations is probably of environmental rather than genetic origin. 
The "new" series, which was carried on at a constant temperature, shows remarkably little fluctuation. Of the two reversed-selection series, one suggests a positive result, but was not carried on long

Table 9.-1002, Inbred Plus Line.

\begin{tabular}{|c|c|c|c|c|c|}
\hline Generation. & $n$ & $M$ & $\sigma$ & $r$ & Diff. $M$. \\
\hline $\begin{array}{l}F_{1} \ldots \ldots \\
F_{2} \ldots \ldots \\
F_{3} \ldots \ldots \\
F_{4} \ldots \ldots \\
F_{5} \ldots \ldots \\
F_{6} \ldots \ldots \\
F_{7} \ldots \ldots \\
F_{8} \ldots \ldots \ldots \\
F_{9} \ldots \ldots \ldots \\
F_{10} \ldots \ldots \ldots \\
F_{11} \ldots \ldots \ldots\end{array}$ & $\begin{array}{r}114 \\
231 \\
446 \\
1,199 \\
1,142 \\
632 \\
283 \\
584 \\
373 \\
269 \\
133 \\
5,406 \\
167 \\
447 \\
377 \\
79 \\
73 \\
128 \\
92 \\
79 \\
1,442\end{array}$ & $\begin{array}{l}5.070 \pm 0.051 \\
5.052 \pm .039 \\
5.473 \pm .025 \\
5.126 \pm .018 \\
5.658 \pm .014 \\
5.389 \pm .022 \\
5.675 \pm .027 \\
5.202 \pm .023 \\
5.507 \pm .027 \\
5.952 \pm .018 \\
6.158 \pm .026\end{array}$ & $\begin{array}{c}0.815 \pm 0.036 \\
.886 \pm .028 \\
.784 \pm .018 \\
.922 \pm .013 \\
.720 \pm .010 \\
.853 \pm .015 \\
.683 \pm .019 \\
.826 \pm .016 \\
.763 \pm .019 \\
.450 \pm .013 \\
.456 \pm .018\end{array}$ & $\begin{array}{l}\ldots \ldots \ldots \ldots \ldots \\
+.157 \pm 0.031 \\
+.153 \pm .019 \\
+.024 \pm .020 \\
+.381 \pm .024 \\
+.305 \pm .036 \\
+.431 \pm .022 \\
+.205 \pm .033 \\
+.025 \pm .040 \\
-.058\end{array}$ & $\begin{array}{l}-0.930 \\
-.918 \\
-. .661 \\
-1.113 \\
-. .397 \\
-1.029 \\
-1.127 \\
-1.122 \\
-.090 \\
-.128 \\
-.477\end{array}$ \\
\hline \multicolumn{6}{|c|}{ Reversed Selection. } \\
\hline $\begin{aligned} \mathrm{F}_{5} \ldots \ldots \ldots \\
\mathrm{F}_{6} \ldots \ldots \ldots \\
\mathrm{F}_{7} \ldots \ldots \ldots \\
\mathrm{F}_{8} \ldots \ldots \ldots \\
\mathrm{F}_{7} \ldots \ldots \ldots \\
\text { New set: } \\
\mathrm{F}_{4} \ldots \ldots \\
\mathrm{F}_{5} \ldots \ldots \\
\mathrm{F}_{4} \ldots \ldots\end{aligned}$ & $\begin{array}{r}62 \\
46 \\
68 \\
23 \\
125\end{array}$ & $\begin{array}{l}5.339 \pm 0.085 \\
4.652 \pm .059 \\
4.147 \pm .062 \\
4.739 \pm .119 \\
4.680 \pm .060 \\
5.898 \pm 0.046 \\
6.000 \pm .000 \\
5.707 \pm .041\end{array}$ & $\begin{array}{r}0.989 \pm 0.060 \\
.890 \pm .063 \\
.753 \pm .044 \\
.845 \pm .084 \\
.993 \pm .042 \\
0.463 \pm 0.032 \\
.000 \pm .000 \\
.573 \pm .028\end{array}$ & 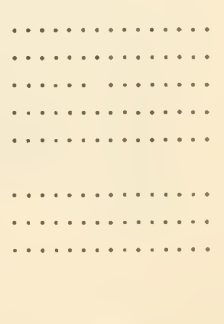 & $\begin{array}{l}+1.339 \\
+.652 \\
+.147 \\
+1.239 \\
+1.180 \\
+0.898 \\
+.500 \\
+\ldots \ldots\end{array}$ \\
\hline
\end{tabular}

${ }^{1}$ Includes reversed selection, that is, not included in the remainder of these data.

enough to be significant, and the other was clcarly without effect. The line was now presumably uniform, and not capable of modification through further selection.

\section{CROSSBRED PLUS SERIES.}

The material for this series came from the following sources: Cultures $902,926,1006,1081$ of the 864 inbred plus line; culture 1072 of 
the 1002 inbred plus line; 2 individuals (in cultures 937 and 1074) from the Dichæt stock; culture 1004, which was made up from exactly the same sources as 1002 (see above), and differed from that culture only in that a single male was used.

This material was mated in various ways, but brother-sister matings were practised infrequently, and then (see Appendix) not often in successive generations. All the cultures in this set were descended from the 864 inbred line; and the "generation" of each culture has been taken as the greatest number of generations from 864 shown by any line of the ancestry of that culture. This method is somewhat misleading, since in every case the "generation" thus given is higher than the average number of selected generations, and still higher than the average number of crossbred selected generations in the pedigree. For example, the first culture in the series, 937, is recorded as $\mathrm{F}_{3}$, since the father came from the $\mathrm{F}_{2}$ generation of the 864 line; but the mother was an unselected individual from the Dichæt stock. Culture 1074 is recorded as $\mathrm{F}_{5}$, though the father was unselected and the mother was from the inbred 864 line. Culture 1254 is recorded as $F_{7}$, though one parent belonged to $F_{5}$, and the only grandparent not an $\mathrm{F}_{4}$ came from 1074, above. This method of grouping the data has been adopted because it is convenient to handle, and because it

Table 10.-Crossbred Plus Series.

\begin{tabular}{|c|c|c|c|c|c|}
\hline Generation. & $n$ & $M$ & $\sigma$ & $r$ & Diff. $M$ \\
\hline $\begin{array}{l}F_{3} \ldots \ldots \ldots \\
F_{4} \ldots \ldots \ldots \\
F_{5} \ldots \ldots \ldots \\
F_{6} \ldots \ldots \ldots \\
F_{7} \ldots \ldots \ldots \\
F_{8} \ldots \ldots \ldots \\
F_{9} \ldots \ldots \ldots \\
F_{10} \ldots \ldots\end{array}$ & $\begin{array}{r}53 \\
417 \\
812 \\
1,031 \\
1,006 \\
877 \\
388 \\
236 \\
4,820\end{array}$ & $\begin{array}{l}5.283 \pm 0.079 \\
5.211 \pm .028 \\
5.489 \pm .018 \\
5.790 \pm .012 \\
5.733 \pm .015 \\
5.616 \pm .018 \\
5.840 \pm .024 \\
5.822 \pm .026\end{array}$ & $\begin{array}{c}0.856 \pm 0.056 \\
.849 \pm .020 \\
.779 \pm .013 \\
.599 \pm .008 \\
.717 \pm .011 \\
.790 \pm .013 \\
.711 \pm .017 \\
.591 \pm .018\end{array}$ & $\begin{array}{l}\ldots \ldots \ldots \ldots \ldots \\
\cdots .156 \pm 0.023 \\
+.027 \pm .021 \\
-.023 \pm .021 \\
-.086 \pm .023 \\
-.147 \pm .034 \\
-.196 \pm .042\end{array}$ & $\begin{array}{l}-1.217 \\
-.719 \\
=.643 \\
=.772 \\
=.891 \\
-1.423 \\
-1.120 \\
-1.589\end{array}$ \\
\hline
\end{tabular}

is desirable for purposes of comparison and computation to have the generations expressed in whole numbers. The errors involved all tend to make it appear that selection has been applied longer than is actually the case, and this should be borne in mind when studying table 10 and the curve (fig. 5) for this series. The pedigrees may be traced from the data in the Appendix, if anyone cares to make a different classification.

Selection has apparently been successful in raising the mean of this series; but this conclusion is not certainly correct, because of the environmental possibilities discussed above. 


\section{INBRED MINUS SERIES.}

As in the case of the inbred plus series, two lines were carried on here. One of these was not kept long; but its history is giren here, chiefly because it was used in producing the crossbred minus line.

900 LiNe.

Culture 900 produced Dichæt flies as shown in table 11.

This culture was produced by mating a male from the sepia, spineless, kidney, sooty, rough stock to a female of the constitution $\frac{D^{1} r_{o}}{s_{e} e}$ that was obtained by inbreeding a pair of flies from 869 (see pedigree of 1002 inbred plus line). 869 was produced by a male from the sepia, spineless, kidney, sooty, rough stock and a feTABLE 11 . male from 854, which came from 839 ( $\%$ ) and $840\left(\sigma^{7}\right) .840$ also enters into the pedigree of the 868 line, below. 839 and 840 were sister pairs, the males coming from the sepia, spineless, kidney, sooty, rough stock, and the females being $F_{1}$ hybrids of the sepia, peach, ebony, and Dichæt stocks.

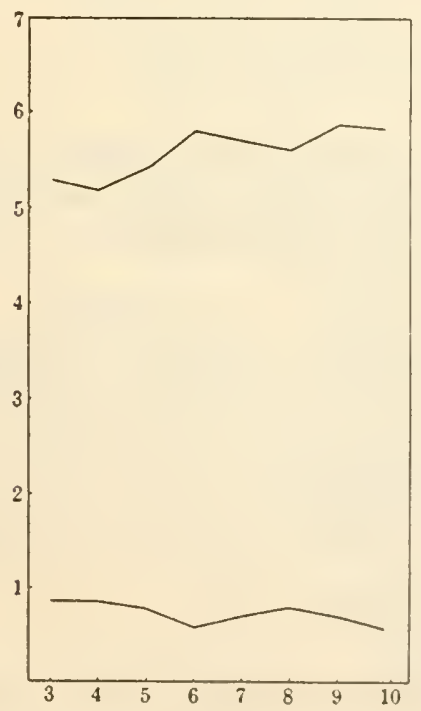

Fig. 5.

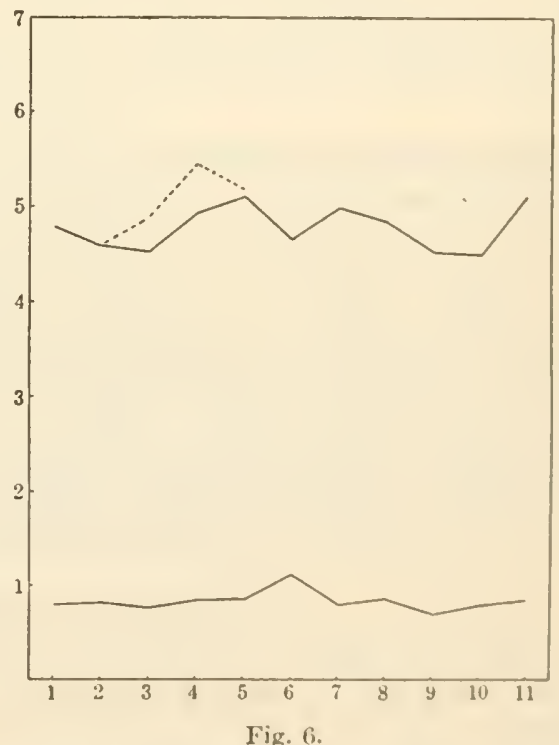

Fig. 6.

FIg. 5.-Means and standard deviations for crossbred plus line

FIG. 6.-Means and standard deviations for 900 inbred minus line.

Table 12 and the curve (fig. 6) for this line are arranged in the same way as those for the inbred plus lines. 
The effectiveness of selection is doubtful, but the line runs consistently lower than the three plus lines, and reversed selection was perhaps effective.

TABLE 12.-900, Inbred Minus Line.

\begin{tabular}{|c|c|c|c|c|c|}
\hline Generation. & $n$ & $M$ & $\sigma$ & $r$ & Diff. M. \\
\hline $\begin{array}{l}F_{1} \ldots \ldots \ldots \\
F_{2} \ldots \ldots \ldots \\
F_{3} \ldots \ldots \ldots \\
F_{4} \ldots \ldots \\
F_{6} \ldots \ldots \ldots \\
F_{6} \ldots \ldots \ldots \\
F_{7} \ldots \ldots \ldots \\
F_{1} \ldots \ldots \ldots \\
F_{9} \ldots \ldots \ldots \\
F_{10} \ldots \ldots \\
F_{11} \ldots \ldots\end{array}$ & $\begin{array}{r}130 \\
204 \\
256 \\
194 \\
243 \\
103 \\
148 \\
69 \\
271 \\
762 \\
340 \\
2,720\end{array}$ & $\begin{array}{l}4.769 \pm 0.045 \\
4.603 \pm .038 \\
4.578 \pm .032 \\
4.959 \pm .040 \\
5.124 \pm .037 \\
4.660 \pm .077 \\
5.000 \pm .044 \\
4.826 \pm .070 \\
4.576 \pm .031 \\
4.555 \pm .019 \\
5.141 \pm .031\end{array}$ & $\begin{array}{r}0.771 \pm 0.032 \\
.794 \pm .027 \\
.767 \pm .023 \\
.818 \pm .029 \\
.847 \pm .026 \\
1.146 \pm .054 \\
.797 \pm .031 \\
.867 \pm .050 \\
.740 \pm .022 \\
.769 \pm .014 \\
.849 \pm .022\end{array}$ & 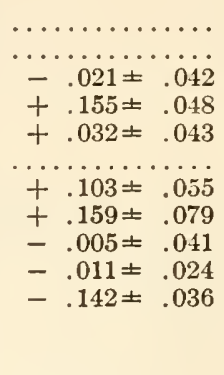 & $\begin{array}{l}+0.769 \\
+.603 \\
+.976 \\
+1.000 \\
+1.255 \\
+.660 \\
+1.986 \\
-.420 \\
+.644 \\
+.654 \\
+1.340\end{array}$ \\
\hline \multicolumn{6}{|c|}{ Reversed Selection. } \\
\hline $\begin{array}{l}\mathbf{F}_{3} \ldots \\
\mathbf{F}_{4} \ldots \\
\mathbf{F}_{6} \ldots\end{array}$ & $\begin{array}{r}68 \\
71 \\
98 \\
237\end{array}$ & $\begin{array}{lr}4.897 \pm & 0.062 \\
5.451 \pm & .062 \\
5.194 \pm & .032\end{array}$ & $\begin{array}{cc}0.750 \pm & 0.044 \\
.728 \pm & .044 \\
.488 \pm & .023\end{array}$ & 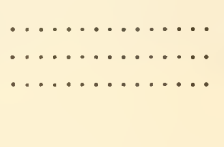 & $\begin{array}{l}-1.103 \\
-.549 \\
-.806\end{array}$ \\
\hline
\end{tabular}

868 Minus Line.

This line is descended from culture 868 , which was produced by a sepia, Dichæt, ebony-sooty female from 856 and a rough male from 852 ; 856 was the result of mating a stock sepia, spineless, kidney, sooty, rough male to a Dichæt ebony-sooty female from 840 ( $q . v$. above, in pedigree of 900 line). 852 was a descendant of the peach, spineless, kidney, sooty, rough, and peachebony stocks, and (although it did not trace to the Dichrt stock) of the same original cultures as 864 , the ancestor of the first inbred plus line (see above).

The offspring of 868 itself were classified for dorso-central bristles, as shown in table 13.

TABLE 13.

\begin{tabular}{|c|c|}
\hline $\begin{array}{l}\text { Dorso- } \\
\text { centrals. }\end{array}$ & Offspring. \\
\hline 0 & 25 \\
\hline 1 & 17 \\
\hline 2 & 9 \\
\hline 3 & 0 \\
\hline 4 & 0 \\
\hline Total... & 51 \\
\hline
\end{tabular}

The data for the succeeding generations are given in table 14 and figure 7 .

The numbers of individuals and of generations are rather small, for the reason that the line was not very vigorous, and finally died out in spite of all attempts to preserve it. It gave the lowest means of any line so far discussed. Reversed selection was apparently successful. 
TABLe 14.-S6s, Inbred Minus Line.

\begin{tabular}{|c|c|c|c|}
\hline Generation. & $n$ & $M I$ & $\sigma$ \\
\hline $\begin{array}{l}\mathrm{F}_{1} \ldots \ldots \ldots \\
\mathrm{F}_{2} \ldots \ldots \ldots \\
\mathrm{F}_{3} \ldots \ldots \ldots \\
\mathrm{F}_{4} \ldots \ldots \ldots \\
\mathrm{F}_{5} \ldots \ldots \ldots \\
\mathrm{F}_{6} \ldots \ldots \ldots\end{array}$ & $\begin{array}{r}74 \\
109 \\
193 \\
68 \\
84 \\
22 \\
550\end{array}$ & $\begin{array}{l}4.432 \pm 0.070 \\
4.688 \pm .053 \\
4.104 \pm .042 \\
3.765 \pm .063 \\
4.286 \pm .053 \\
4.228 \pm .106\end{array}$ & $\begin{array}{c}0.888 \pm 0.049 \\
.820 \pm .037 \\
.834 \pm .029 \\
.768 \pm .044 \\
.716 \pm .037 \\
.736 \pm .075\end{array}$ \\
\hline \multicolumn{4}{|c|}{ Reversed Selection. } \\
\hline $\begin{array}{l}\mathrm{F}_{4} \ldots \ldots \ldots \ldots \\
\mathrm{F}_{6} \ldots \ldots \ldots \ldots\end{array}$ & $\frac{112}{225}$ & $\begin{array}{l}4.732 \pm 0.055 \\
4.862 \pm .039\end{array}$ & $\begin{array}{r}0.856 \pm 0.03 S \\
.866 \pm .027\end{array}$ \\
\hline
\end{tabular}

CROSSBRED MINUS SERIES.

The following cultures furnished the material for this series:

Cultures $920,1063,1073,1082$ of the 900 minus line.

Cultures $935,936,1047$ of the 868 minus line.

Culture 942, made up by mating together two 4-bristled Dichæts from 912 , which in turn was the result of mating a sepia, spineless, kidney, sooty, rough male to a female from a daughter culture of 869 (see pedigree of 900 line).

Culture 949, made up by mating a female of the constitution $\frac{D^{\prime} p^{p} S_{s} e^{8} r_{0}}{p^{p} S_{6} e^{8} r_{0}}$ (from the cultures of Mr. J. W. Gowen) to a male from culture 916 (see pedigree of 1002 line).

All the cultures in this series traced to 868 , and the "generation" given is the greatest number of generations from 868 , which is thus the standard for this line, just as 864 was for the crossbred plus series.

Table 15 and figure 8 give the results for the series. Here again, the effectiveness of selection is suggested, but is doubtful. The means, however, are lower than in any other series except the S6S line, and that line entered very largely into the make-up of this one.

Speck Mrnos or 1331 Line.

In connection with eertain experiments to be described below it became desirable to have a minus line that should be recessive for some second chromosome character. Accordingly culture 1331 was made up by mating a 4 female from $1168, \mathrm{~F}_{6}$ of the crossbred minus series, to a speck male. ${ }^{1}$ The line was then inbred, in pairs, brother to sister, minus selected, and gradually made homozygous for speck, sepia, and rough. 


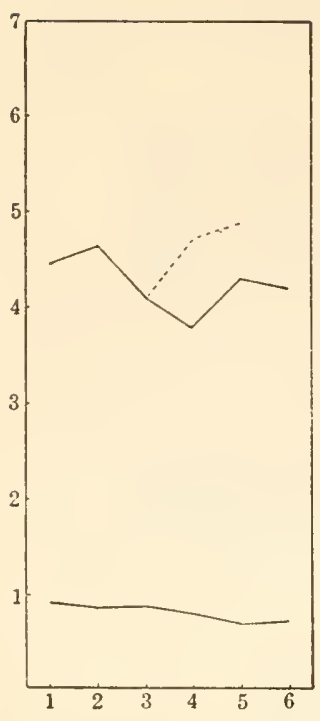

Fig. 7 .

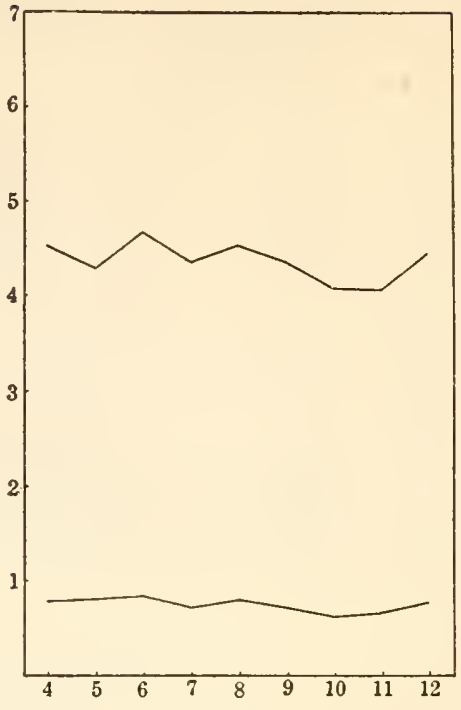

Fig. 8.

FIG. 7.-Means and standard deviations for 868 inbred minus line. FIG. 8.-Means and standard deviations for crossbred minus line.

TABLE 15.-Crossbred Minus Series.

\begin{tabular}{|c|c|c|c|c|c|}
\hline Generation. & $n$ & $M$ & $\sigma$ & $r$ & Diff. M. \\
\hline $\begin{array}{l}F_{4} \ldots \ldots \ldots \\
F_{5} \ldots \ldots \ldots \\
F_{6} \ldots \ldots \ldots \\
F_{7} \ldots \ldots \\
F_{8} \ldots \ldots \\
F_{9} \ldots \ldots \\
F_{10} \ldots \ldots \\
F_{11} \ldots \ldots \\
F_{12} \ldots \ldots\end{array}$ & $\begin{array}{r}323 \\
688 \\
1,022 \\
1,473 \\
1,503 \\
401 \\
265 \\
245 \\
177 \\
6,097\end{array}$ & $\begin{array}{l}4.523 \pm 0.028 \\
4.297 \pm .020 \\
4.667 \pm .017 \\
4.357 \pm .013 \\
4.522 \pm .014 \\
4.354 \pm .025 \\
4.083 \pm .026 \\
4.073 \pm .030 \\
4.475 \pm .039\end{array}$ & $\begin{array}{r}0.753 \pm 0.020 \\
.786 \pm .014 \\
.829 \pm .012 \\
.735 \pm .009 \\
.788 \pm .010 \\
.730 \pm .017 \\
.621 \pm .018 \\
.666 \pm .021 \\
.767 \pm .027\end{array}$ & $\begin{array}{l}+0.070 \pm 0.026 \\
-.018 \pm .021 \\
-.151 \pm .017 \\
\pm .026 \pm .016 \\
-.142 \pm .033 \\
\pm .107 \pm .041 \\
\pm .230 \pm .041 \\
-.191 \pm .049\end{array}$ & $\begin{array}{l}+0.523 \\
+.711 \\
+1.280 \\
+.558 \\
+1.055 \\
+. .742 \\
+.511 \\
+1.008 \\
+1.334\end{array}$ \\
\hline
\end{tabular}

${ }^{1}$ From $F_{6}$ of the inbred speck line described later.

Table 16 and figure 9 show the result. The break after $\mathrm{F}_{8}$ represents the same treatment as that given to the 1002 line (p. 10)-i.e., two generations of unselected mass cultures.

This line gives perhaps the clearest evidence of the effectiveness of selection that we have yet observed. Reversed selection begun in $\mathrm{F}_{2}$ was apparently also successful. Finally, the line after $\mathrm{F}_{2}$ gives consistently lower means than any other here recorded. 


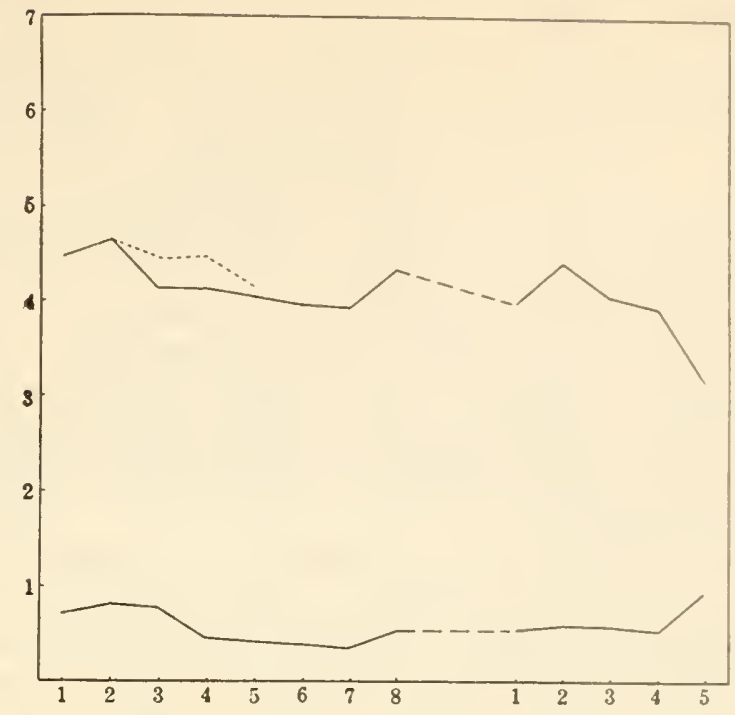

FIG. 9.-Means and standard deviations for speck (1331) minus line.

TABLe 16.-1981 (Speck), Minus Line.

\begin{tabular}{|c|c|c|c|c|c|}
\hline $\begin{array}{c}\text { Genera- } \\
\text { tion. }\end{array}$ & $n$ & $M$ & $\sigma$ & $r$ & Diff. M. \\
\hline $\begin{array}{c}F_{1} \ldots \ldots \\
F_{2} \ldots \ldots \\
F_{3} \ldots \ldots \\
F_{4} \ldots \ldots \\
F_{5} \ldots \ldots \\
F_{6} \ldots \ldots \\
F_{7} \ldots \ldots \\
F_{8} \ldots \ldots \\
\text { New set: } \\
F_{1} \ldots \\
F_{2} \ldots \\
F_{3} \ldots \\
F_{4} \ldots \\
F_{5} \ldots\end{array}$ & $\begin{array}{r}125 \\
295 \\
395 \\
377 \\
307 \\
169 \\
159 \\
27 \\
\\
21 \\
36 \\
99 \\
163 \\
16 \\
2,192\end{array}$ & $\begin{array}{l}4.464 \pm 0.044 \\
4.688 \pm .031 \\
4.187 \pm .026 \\
4.141 \pm .017 \\
4.072 \pm .016 \\
3.982 \pm .022 \\
3.943 \pm .019 \\
4.333 \pm .071 \\
4.000 \pm 0.076 \\
4.417 \pm .072 \\
4.051 \pm .045 \\
3.951 \pm .031 \\
3.188 \pm .167\end{array}$ & $\begin{array}{c}0.733 \pm 0.031 \\
.790 \pm .022 \\
.767 \pm .018 \\
.495 \pm .012 \\
.425 \pm .012 \\
.414 \pm .015 \\
.341 \pm .013 \\
.547 \pm .050 \\
0.535 \pm 0.048 \\
.638 \pm .051 \\
.629 \pm .031 \\
.584 \pm .028 \\
.948 \pm .118\end{array}$ &  & $\begin{array}{l}+0.896 \\
1-.435 \\
1-.134 \\
1+.303 \\
+.304 \\
+.399 \\
+1.333 \\
+1.000 \\
+.417 \\
+.081 \\
2+.295 \\
+.188\end{array}$ \\
\hline \multicolumn{6}{|c|}{ Reversed Selection. } \\
\hline $\begin{array}{l}F_{3} \ldots \\
F_{4} \ldots \\
F_{5} \ldots\end{array}$ & $\begin{array}{r}161 \\
91 \\
21 \\
273\end{array}$ & $\begin{array}{l}4.429 \pm 0.035 \\
4.451 \pm .052 \\
4.143 \pm .114\end{array}$ & $\begin{array}{c}0.663 \pm 0.025 \\
.743 \pm .037 \\
.773 \pm .050\end{array}$ & & \\
\hline
\end{tabular}

'Includes data from reversed selection.

${ }^{2}$ Includes culture 2625, a mating of $6 \times 6$. This culture is not included in the other columns. 


\section{GENERAL RESULTS OF SELECTION EXPERIMENTS.}

In every case the selected lines showed means that differed from the mean of unselected Dichæts in the direction in which selection had been carried on. Owing to the apparently large environmental infiuence on bristle number, it is in most cases difficult to be sure how this result was brought about, or, rather, at what stage in the process.

In the case of the 1331 (speck) minus line, however, the change seems to have been effected fairly rapidly at first, and slowly, if at all, later on. In the case of the 1002 line there was probably no effect in the later generations. Reversed selection was uniformly successful if begun in the early generations, but not usually so at later stages. These are the results that would be expected on the view that modifying genes are involved.

It is to be observed in the case of the plus lines that the means vary inversely as the standard deviations - that is, that the two curves are much like mirror images. In the minus lines the two quantities usually vary together, giving curves that are nearly parallel. These relations hold surprisingly closely for many of the curves, especially those of the plus lines. They are due to the fact that a change in the mean is almost always brought about by an elimination or great decrease in the number of individuals at one extreme of the population rather than by a marked change in the position of the mode or of the other extreme. This is strongly in favor of the view that selection has been effective in eliminating "unfavorable" combinations rather than in producing entirely new types.

The relation between the crossbred and inbred series is too much obscured to repay detailed analysis. Evidently such experiments with this character would have to be carried out under carefully controlled environmental conditions before they could have any great significance.

\section{CROSS OF TWO INBRED PLUS LINES.}

Since the two inbred plus lines, 864 and 1002, came from slightly different sources (see above), and were kept separate while being plus selected, it seemed possible that different plus modifiers had been isolated in the two lines. If this were the case, crossing them should result in increasing the variability in $\mathrm{F}_{2}$, and the parent-offspring correlation when the $\mathrm{F}_{2}$ individuals were bred to produce $\mathrm{F}_{3}$. The $\mathrm{F}_{2}$ population should contain genetically unlike individuals, and should yield to selection in either direction. As a matter of fact, no such result was obtained.

Table 17 gives the result of the experiment. The 1941 set is perhaps the clearest case, so we may consider it alone. The parents of 1941 came from $1763\left(F_{10}\right.$ of the 864 line) and $1788\left(F_{7}\right.$ of the 1002 line). As table 17 and figure 10 show, the standard deviation in $\mathrm{F}_{2}$ 
Table 17.-Inbred Plus Lines Crossed.

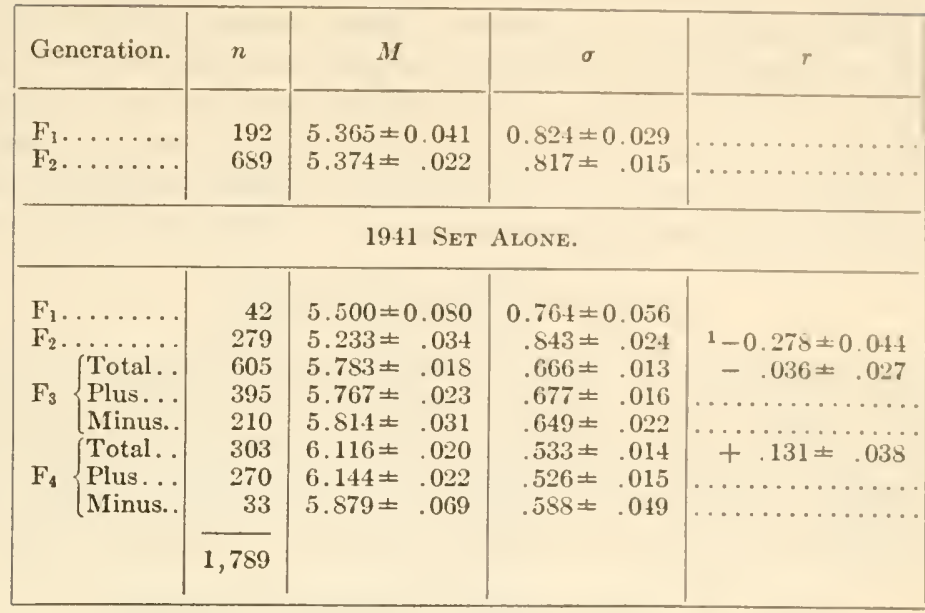

1 Does not include culture 2054, in which the mother was not-Dichæt.

10

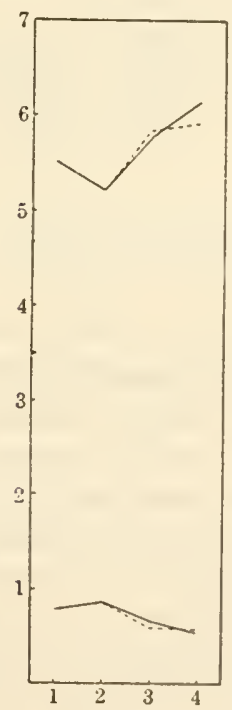

11

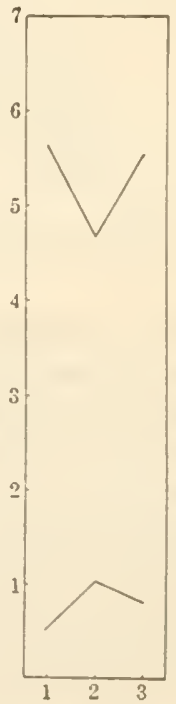

Fig. 10.-Means and standard deviations for cross of two inbred plus lines.

Fig. 11.-Means and standard deviations for cross of 1002 inbred plus and speck (1331) minus lines.

was nearly the same as that in $F_{1}$, the $F_{2}-F_{3}$ and $F_{3}-F_{4}$ parent-offspring correlations were not significantly different from 0 , and the means of the plus and minus selected series in $F_{3}$ and $F_{4}$ were practically identical. This constitutes practically a proof that the two lines did not differ with respect to modifying genes. The result, while surprising, is by no means highly improbable on the multiple-factor view. The 
two lines both came in large part from the sepia, spineless, kidney, sooty, rough, and peach, spineless, kidney, sooty, rough stocks, and therefore selection presumably had similar material to work with in both cases. That the result was the same is, then, only a somewhat unexpected coincidence. It may be pointed out that the identity of the two lines is borne out by their very similar behavior after the seventh and tenth generations, respectively. (See figs. 3 and 4, above.)

\section{CROSS OF PLUS AND MINUS LINE.}

When two races that differ in quantitative characters are crossed, the usual result is an increased variability in $\mathrm{F}_{2}$ and an increased $\mathrm{F}_{2}-\mathrm{F}_{3}$ parent-offspring correlation. This result was obtained in the present case, as is shown by table 18 and figures 11 and 12, which give the data for a cross of the 1002 plus and 1331 minus lines.

TABLE 18.-Cross of Inbred Plus and Inbred Minus Lines.

\begin{tabular}{|c|c|c|c|c|}
\hline Generation. & $n$ & $M$ & $\sigma$ & $r$ \\
\hline $\begin{array}{c}\mathrm{F}_{1} \ldots \ldots \ldots \\
\mathrm{F}_{2} \ldots \ldots \ldots \\
\mathrm{F}_{3} \ldots \ldots \ldots \\
{ }^{1} \mathrm{~F}_{3} \ldots \ldots\end{array}$ & $\begin{array}{r}53 \\
369 \\
1,133 \\
1,078 \\
1,555\end{array}$ & $\begin{array}{l}5.679 \pm 0.049 \\
4.694 \pm .037 \\
5.524 \pm .016 \\
5.492 \pm .013\end{array}$ & $\begin{array}{r}0.542 \pm 0.035 \\
1.052 \pm .026 \\
.787 \pm .011 \\
.610 \pm .009\end{array}$ & $\begin{array}{l}+0.193 \pm 0.034 \\
+.258 \pm .019 \\
+.330 \pm .019\end{array}$ \\
\hline
\end{tabular}

${ }^{1}$ Calculated after elimination of aberrant culture 3077 .

Such a result is capable of explanation in either of two ways. It may be due to the segregation of modifying factors, or it may be due to contamination of unlike allelomorphs in the $F_{1}$ individuals.

The contamination hypothesis presents some unusual features in the present case; for the $F_{1}$ Dichæts were not heterozygous for one plus Dichæt gene and one minus one; homozygous Dichæts always die. Half of them had one plus selected Dichæt gene and one minus selected normal allelomorph of Dichæt (i.e., not-Dichæt), the other half had one minus selected Dichrt and one plus selected not-Dichæt. Both not-Dichæts, when homozygous, give for the most part 8-bristled flies, which are more "plus" than any Dichæt race. Nevertheless, on the contamination view, each must contaminate its mate in the $F_{1}$ fly, in the direction in which it has been selected. Even the minus selected not-Dichrt, that makes for 8 bristles, must contaminate the plus selected Dichæt, that makes for 6 bristles, in such a way that the resulting Dichæt gene makes for only 4 or 5 bristles. That is, "plusness" or "minusness" and "Dichætness" must be separable, and a degree of "minusness" that affects the result produced by a not-Dichrt gene only very slightly must nevertheless be capable of 
transference to a Dichæt gene and must materially affect the result produced by that Dichæt gene.

The hypothesis that modifying genes are responsible for the result meets with no such complications.

\section{LOCATION OF MODIFYING GENES.}

The selection experiments recorded above have demonstrated that Dichæt lines exist that are genetically different with respect to bristle number. The cross between the 1002 plus line and 1331 minus line showed that there is an increase in variability in $\mathrm{F}_{2}$ when two such lines are crossed. Both these facts are consistent with the view that modifying genes, other than the Dichrt gene itself, have influenced the bristle number of Dichæt flies. But it would also be possible to interpret the result as due to variations in the Dichæt gene itself, and to contamination of that gene in crosses. (See above.)

It has been pointed out by Muller and Altenburg (Morgan, Sturtevant, Muller and Bridges, 1915, p. 191), by Dexter (1914), and by Muller (1917) that there is a method of distinguishing between these two possibilities. The truncate race of Drosophila with which Muller and Altenburg worked is characterized by shortened "truncated" wings. The race does not breed true for the truncate character, but the percentage of truncates produced and the degree of truncation shown are both capable of modification by selection. Muller and
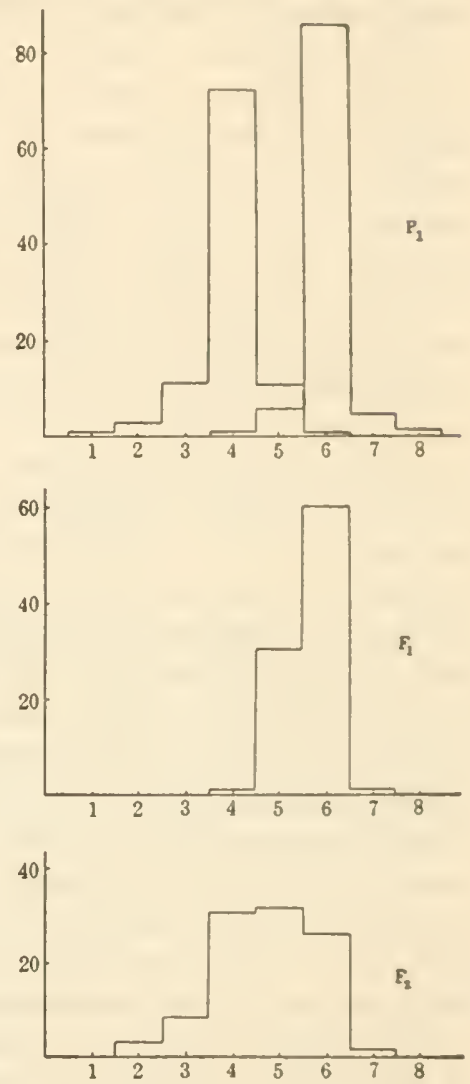

FIG. 12.-Results of crossing 1002 inbred plus and speck (1331) minus lines. The $P_{1}$ curves represent the last few generations of each parent race. All four curves are reduced to the percentage basis; the ordinates represent percentages and the abscissie bristle numbers.

Altenburg showed that this race contains a mutant gene in the second chromosome that is primarily responsible for the truncate character. By means of linkage experiments involving readily classifiable mutant characters they were able also to show that there are modifying factors for the truncate character in the first and in the third chromosomes. Furthermore, when the stock was by special methods kept uniform in constitution with respect to the truncate gene itself and with respect to these modifiers, selection was without effect. In this way the genetic variability of the race was shown to be due to modifying factors. 
Dexter (1914) showed by similar methods that the chief gene for the variable character beaded is in the third chromosome, and that there is a modifier in the second chromosome. These results have been rerified by Muller (1917).

In making such tests for modifying factors it is very desirable that the test stocks, as well as the selected stocks that are to be tested, should be homogeneous for modifying genes. This is desirable in order that the tests may be repeated, and in order that results obtained with different stocks may be compared. It was for this purpose that the speck minus, or 1331, line of this paper was obtained. (See above for history of this line.) This line, in the later generations, was homozygous for the recessive mutants speck (chromosome II) and sepia and rough (chromosome III). Since it had been inbred and minus selected for several generations, it was probably uniform in constitution with respect to modifiers. Since the other selected lines also became homozygous for rough in later generations, it was desirable to have a uniform not-rough line. For this purpose a pair was taken from the speck stock, wild type in other characters. From this pair a line was established, and continued by strict brother-sister pair matings, in order to obtain a stock nearly or quite homozygous for all its genes. This material is designated "speck stock." All individuals from it that were used for test purposes came from 8 or more successive brother-sister matings. ${ }^{1}$

Sex-linked modifiers would become apparent in $\mathrm{F}_{1}$ when two races were crossed, since the males from reciprocal crosses would differ and each type would resemble the maternal race. There is no clear evidence of the existence of such modifiers in this experiment, so the sex chromosome will be ignored in the discussion that follows.

The method used for detecting second-chromosome modifiers is as follows: Two lines are crossed, one of which contains speck, the other not; one or both have Dichæt (fig. 13). The $F_{1}$ Dichæts are then heterozygous for speck, and for any second-chromosome modifiers in which the two lines were different. If an $\mathrm{F}_{1}$ male is now mated to a speck not-Dichæt female, there will be no crossing over between speck and the modifiers. Therefore the not-speck Dichæts produced will receive second chromosomes from their father which will be identical with those present in the $P_{1}$ not-speck race (in the diagram the Dichæt race), while the speck-Dichæt back-cross individuals will receive the second chromosome that came from the other $\mathrm{P}_{1}$ race. Since the two types are alike in their third chromosome constitution, and since they have been reared in the same culture bottles, so that environmental influences were the same, any differences

\footnotetext{
1 With the exception of culture 1737 (see Appendix), all were from 10 or more successive brothersister matings. All these specks were from the same $\mathrm{F}_{5}$ pair. All those before culture 2430 were from the same $F_{8}$ pair. All those after 2430 were from a different $F_{8}$ pair, but were themselves from the same $F_{17}$ pair. $F_{15}$ and $F_{16}$ were mass cultures instead of pairs.
} 
between them must be due to second-chromosome differences between the two $P_{1}$ races. This experiment may be contimued further by mating the not-speck Dichrt males produced by the back-cross to the speck not-Dichrt females. Such a mating should give the same result
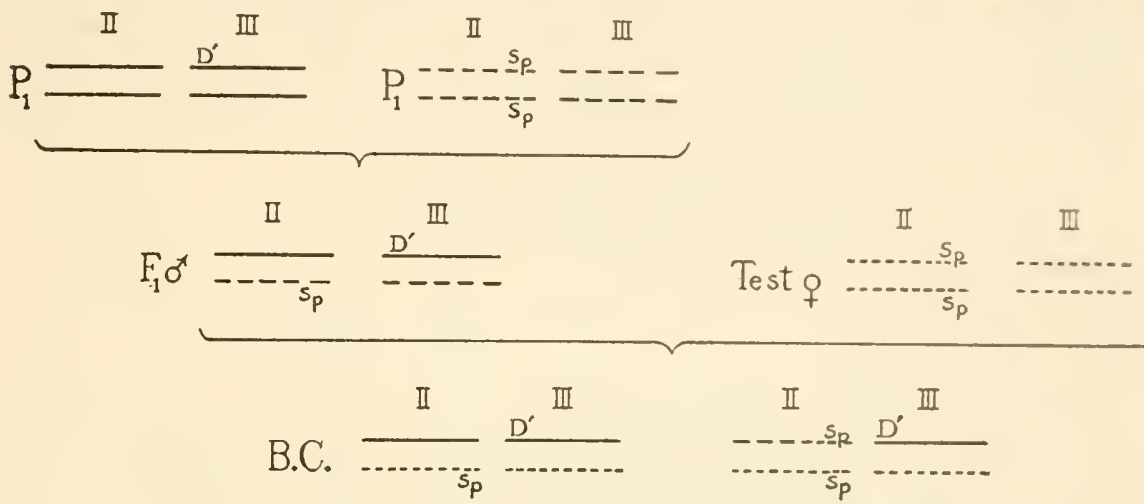

FIG. 13.

as the first back-cross and does in fact do so. In table 19 both types of experiment are treated together. Figure 14 is a graphical representation of the result of one experiment of the type here described.

It should be moted that such experiments are suited only for the detection of dominant modifiers present in one $P_{1}$ race, or, stated conversely, recessives present both in onc $P_{1}$ race and in the speck race from which the test female came.

TABle 19.- - T Tests, Chromosome II.

\begin{tabular}{|c|c|c|c|c|c|c|c|c|}
\hline \multicolumn{2}{|c|}{ Source. } & \multirow{2}{*}{$\begin{array}{c}\text { Tested } \\
\text { against- }\end{array}$} & \multicolumn{4}{|c|}{ Means. } & \multicolumn{2}{|c|}{ Distributions. } \\
\hline Not-sp. & sp. & & Not-sp. & sp. & Diff. & $\frac{\text { Diff. }}{\text { P. E. }}$ & $x^{2}$ & $P$ \\
\hline 864. & sp. stock & sp. stock & $5.314 \pm 0.045$ & $4.462 \pm 0.050$ & $+0.852 \pm 0.067$ & 12.7 & 69.4 & $0.000000+$ \\
\hline 1002 . & sp. stock & sp. stock & $5.924=.026$ & $5.732 \pm .031$ & $+.192 \pm .040$ & 4.8 & 13.3 & .004 \\
\hline $1002 \ldots$ & sp. stock & 1331 & $5.824 \pm .062$ & $5.385 \pm .117$ & $+.439=.132$ & 3.3 & 4.77 & .10 \\
\hline $1002 \ldots$ & 1331 & 1331 & $4.9 S 3 \pm .063$ & $4.438 \pm .065$ & $+.545 \pm .091$ & 6.0 & 17.7 & .001 \\
\hline 1002 . & 1331 & sp. stock & $6.095=.043$ & $5.750 \pm .104$ & $+.345 \pm .113$ & 3.1 & 6.17 & .05 \\
\hline Cross-br. plus. & sp. stock & sp. stock & $5.412 \pm .063$ & $4.686 \pm .097$ & $+.726 \pm .116$ & 6.3 & 19.0 & .0003 \\
\hline $900 \ldots \ldots \ldots$ & sp. stock & sp. stock & $4.711 \neq .062$ & $4.442 \pm .070$ & $+.26 \mathrm{~s}=.093$ & 2.9 & 3.95 & 27 \\
\hline Cross-br. minus. & sp. stock & sp. stock & $5.304 \pm .057$ & $4.762 \pm .101$ & $+.5 .12 \pm .133$ & +1 & $66 \%$ & 04 \\
\hline Cross-br. minus. & sp. stock & 1331 & $4.353 \pm .067$ & $4.151 \pm .045$ & $+.202 \pm .081$ & 2.5 & 5.59 & .24 \\
\hline
\end{tabular}

Table 19 gives the results of the experiments of this type that have been earried out. (For the raw data see Appendix.) 'The first two columns give the $P_{1}$ races, or in eases where the tested mate came himself from a back-cross test, the original source of his not-speck and speck chromosomes. The third column gives the source of the test female. All tests in which the data for these three columns were identical have becn lumped. The next three columns give the mean 
bristle number of the two classes of Dichæt offspring and the difference between these two means. The sign of the difference is given as positive when the not-specks had a higher mean than the specks (as in all these cases); negative, as in other results (see below), when the specks were higher. In the col-

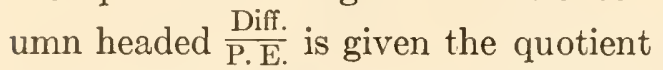
of the difference between the two means divided by its own probable error, a measure of the probable significance of that difference. The last two columns give the $\chi^{2}$ and $P$ values for the two (speck and not speck) distributions, considered as wholes.

These data make it certain that the 864 plus line and crossbred plus line both contained second chromosomes with one or more plus modifiers dominant to minus modifiers in the second chromosome of the speck stock. The 1002 plus line had similar modifiers, and also had the same relation to the 1331 minus line. It is probable, from the results obtained with the 1002 line, that the speck stock and the 1331 line had some minus modifiers in common, but that the second chromosome of the 1331 line was more strongly minus. Both these latter results would have been expected, since the second chromosome of the 1331 line came, in part at least, from that of the speck stock,

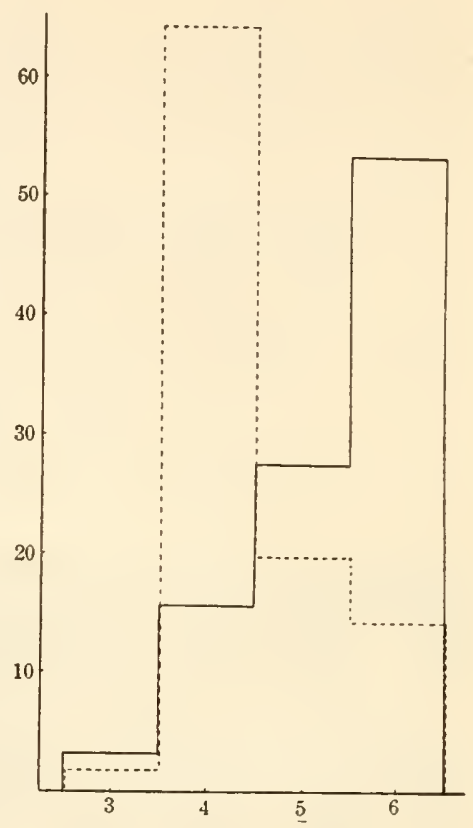

Fig. 14,-Not-speck (solid line) and speck (broken line) offspring from male back-cross tests of 864 inbred plus line against speck stock. Curves, based on 153 not-speck and 106 speck flies, are both reduced to the percentage basis. See table 19 for statistical treatment.

but has been minus selected, while the speck stock has not been selected at all for bristle number.

The experiments just discussed show that the second chromosome contains one or more modifiers, but give us no information regarding the loci of such modifiers. It is possible, on the basis of this data alone, that speck itself is the minus modifier. If, however, a heterozygous female is tested by mating to a speck not-Dichæt male, there will be a possibility of crossing over between speck and any modifiers in the second chromosome. The result would be that the speck and not-speck offspring differ less than when an $F_{1}$ male is tested. There is, of course, also an opportunity for crossing over in the third chromosomes of such females, so that the Dichæt offspring will not be all alike with respect to their third chromosomes, as they were when the male was tested; but the same crossover classes should occur among 
both the speck and the not-speck offspring, and in identical proportions. Therefore this factor should not influence the end-result.

Table 20 shows the results obtained from such experiments. The arrangement is the same as in table 19.

As was expected, the differences here are less than in the corresponding tests, but are still present and in the same direction when significant. This result proves that one or more of the second-chromosome modifiers cross over from speck in the female.

TABLE 20.- o Tests, Chromosome $I I$.

\begin{tabular}{|c|c|c|c|c|c|c|c|c|}
\hline \multicolumn{2}{|l|}{ Source. } & \multirow{2}{*}{$\begin{array}{c}\text { Tested } \\
\text { against- }\end{array}$} & \multicolumn{4}{|c|}{ Means. } & \multicolumn{2}{|c|}{ Distributions } \\
\hline Not-sp. & sp. & & Not-sp. & sp. & Diff. & $\frac{\text { Diff. }}{\text { P. E. }}$ & $\chi^{2}$ & $\mathrm{P}$ \\
\hline 864. & sp. stock & 1331 & $4.971 \pm 0.097$ & $4.600 \pm 0.082$ & $+0.371 \pm 0.127$ & 2.9 & 4.59 & 0.21 \\
\hline 864. & 1331 & sp. stock & $4.674 \pm .059$ & $4.321 \pm .067$ & $+.353 \pm .059$ & 4.0 & 9.10 & .06 \\
\hline 864. & 1331 & 1331 & $4.448 \pm .043$ & $4.245 \pm .044$ & $+.203 \pm .062$ & 3.3 & 13.1 & .004 \\
\hline 1002. & sp. stock & sp. stock & $5.543 \pm .074$ & $5.393 \pm .104$ & $+.150 \pm .128$ & 1.2 & 2.78 & .43 \\
\hline 1002. & sp. stoek & 1331 & $4.875 \pm .062$ & $4.787 \pm .070$ & $+.088 \pm .093$ & 0.9 & 1.39 & .92 \\
\hline 1002. & 1331 & 1331 & $4.617 \pm .046$ & $4.250 \pm .056$ & $+.367 \pm .073$ & 5.0 & 13.8 & .03 \\
\hline 1002. & 1331 & sp. stock & $5.336 \pm .027$ & $5.390 \pm .048$ & $-.054 \pm .055$ & 1.0 & 8.93 & .26 \\
\hline Cross-br. minus. & sp. stoek & 1331 & $5.259 \pm .097$ & $4.727 \pm .152$ & $+.532 \pm .180$ & 3.0 & 7.97 & .05 \\
\hline Cross-br. minus. & sp. stock & sp. stock & $4.350 \pm .086$ & $4.609 \pm .090$ & $-.259 \pm .125$ & 2.1 & 2.21 & .34 \\
\hline
\end{tabular}

THIRD-CHROMOSOME MODIFIER.

If we cross two races, one of which is Dichat rough, the other wildtype, the $\mathrm{F}_{1}$ female will have the constitution $D^{\prime} r_{o}$. If such a female be mated to a not-Dichrt rough male, there will be two types of Dichæt offspring - the non-crossovers will be rough, the crossovers not rough. ${ }^{1}$ If the two original chromosomes differed in modifying factors somewhere near rough, these two types of offspring will differ in their bristle number.

Such tests have been carried out, with the results shown in table $21 .^{2}$ In only one case (the third) was a significant difference obtained; but that case proves that there was a dominant plus modifier in the 1002 line, located somewhere near rough, or a dominant minus modifier in the speck stock, but not in the 1331 line and in the same region. Since the 1331 line was derived from a cross involving the speck stock, and had been minus selected ever since that cross, it is probable that dominant minus modifiers present in the speck stock would have been preserved in the 1331 line. It is, therefore, almost certain that the

\footnotetext{
1 There will be some doubie crossovers, but these will be rare. There will, be course, also he two classes of not-Dichrts.

2 In the case recorded in the second row, the Dichet and rough came from different parents, so that the non-crossover and crossover classes are reversed. The experiment is the same in prineiple as that outlined above.
} 
1002 line contained a dominant plus modifier in the region of the rough locus. ${ }^{1}$

There can be no question that the lines studied do differ in their constitution with respect to definite modifying genes that affect bristle number. In the case of the 1002 and 1331 lines there is at least one modifier, and probably two, located in different chromosomes. This gives the explanation of the increased variability observed in $F_{2}$ when these lines were crossed. The only other available explanation of that phenomenon-contamination of allelomorphs-has already been shown above to lead to complications in this case. (See also below.) Since it is both improbable and unnecessary, it may safely be discarded.

TABLE 21.- - Tests, Chromosome III.

\begin{tabular}{|c|c|c|c|c|c|c|c|c|}
\hline \multicolumn{2}{|c|}{ Source. } & \multirow{2}{*}{$\begin{array}{c}\text { Tested } \\
\text { against- }\end{array}$} & \multicolumn{4}{|c|}{ Means. } & \multicolumn{2}{|c|}{ Distributions. } \\
\hline Not-ro. & ro. & & Not-ro. & ro. & Diff. & $\frac{\text { Diff. }}{\text { P.E. }}$ & $\chi^{2}$ & $\mathrm{P}$ \\
\hline Sp. stock. & 864 & 1331 & $4.793 \pm 0.106$ & $4.761 \pm 0.081$ & $-0.032 \pm 0.133$ & 0.2 & 1.76 & 0.60 \\
\hline $1002 \ldots$ & 1331 & 1331 & $4.750 \pm .071$ & $4.581 \pm .091$ & $+.169 \pm .115$ & 1.5 & 1.09 & .58 \\
\hline Sp. stock. & 1002 & 1331 & $4.697 \pm .065$ & $5.098 \pm .042$ & $+.401 \pm .077$ & 5.2 & 18.7 & .002 \\
\hline Sp. stock. & cross-br. minus & 1331 & $4.323 \pm .089$ & $4.276 \pm .092$ & $-.047 \pm .127$ & 0.4 & 0.33 & .999 \\
\hline
\end{tabular}

THIRD-CHROMOSOME LETHALS.

Culture 1264, belonging to the third generation of the 1002 inbred plus line, produced, in the last 6 days it was counted, 60 Dichæts and no not-Dichæts. It seemed possible that one of the parents was homozygous for Dichæt, so the line was continued. It was finally bred through about 18 generations, and produced 2,735 Dichæts and only 4 not-Dichæts. The 4 not-Dichæts suggest the hypothesis that all the Dichrts are really heterozygous as usual, but that they carry a lethal in the other chromosome that kills the not-Dichæts. ${ }^{2}$ That they are heterozygous has been shown by out-crossing them. When mated to Dichæts of other strains the result was 211 Dichæts to 103 not-Dichæts (4 cultures), the $2: 1$ ratio usually obtained when Dichæts are mated together. When mated to not-Dichæts the result was 207 Dichæts to 209 not-Dichæts (6 cultures)-a normal 1: 1 ratio. That there is a lethal in the stock has been shown by mating Dichæts of this strain to Extended flies and inbreeding the not-Dichæt offspring, which were found to carry a lethal as expected. (See below.)

\footnotetext{
${ }^{1}$ The second row of table 18 seems to contradict the conclusion that the 1002 and 1331 lines differed with respect to a modifier near rough. However, the experiment represents only a few flies, and did not give a significant result. Moreover, it was carried out before the 1002 line had been very long inbred $\left(\mathrm{F}_{8}\right)$, and involved a not-rough chromosome from that line, which had not then become homozygous for rough.

2 See Muller (1917) for a discussion of autosomal lethals.
} 
The 4 not-Dichæt flies produced by uncrossed descendants of 1264 appeared in cultures $1516,2424,2571$, and 2851. Since most of the flies of this line are heterozygous for other factors in chromosome III, it should be possible by an examination of these 4 flies to determine on which side of Dichrt the lethal lies; for these flies are eridently crossovers between Dichrt and the lethal, and should show certain relations with the other characters, depending on the locus of the factor.

The 4 cultures in question gave the results shown in table 22 (both parents in 1264 being rough, all these flies are rough).

TABLE 22 .

\begin{tabular}{|c|c|c|c|c|c|c|}
\hline & $\mathrm{D}^{\prime}$. & $\mathrm{D}^{\prime}$ ss so. & $\mathrm{D}^{\prime}$ so. & not-D'. & not-D' ss. & not- $D^{\prime}$ so. \\
\hline 1516 & 106 & 6 & 4 & 1 & 0 & 0 \\
\hline 2424 & \multirow{2}{*}{\multicolumn{3}{|c|}{$\begin{array}{l}78 \text { Dichæts, some ss. } \\
49 \text { Dichæts, with some } D^{\prime} \text { pe ss so }\end{array}$}} & 0 & 1 & \\
\hline 2571 & & & & 0 & 0 & 1 \\
\hline 2851 & \multicolumn{5}{|c|}{41 Dichxts, 1 not $D^{\prime}$; other characters not noted. } & \\
\hline
\end{tabular}

Since the other characters were not noted in 2851, that bottle is useless for our present purposes. The constitution of the parents in the other three cultures must have been as follows:

$\begin{array}{lll}\text { 1516: } & \frac{D^{\prime}}{l_{\mathrm{III}} s_{s} e^{s}} & \frac{D^{\prime}}{l_{\mathrm{III} s_{s}} e^{s}} \\ \text { 2424: } & \frac{D^{\prime}}{l_{\mathrm{III} s_{s}}} & \frac{D^{\prime}}{l_{\mathrm{III} s_{s}}} \\ \text { 2571: } & \frac{D^{\prime}}{l_{\mathrm{III}} p^{p} s_{s} e^{f}} & \frac{D^{\prime}}{l p^{p} s_{s} e^{s}}\end{array}$

Since there can be no crossing over in the male, there must in each case have been a crossover between $D^{\prime}$ and $l_{\text {ut }}$ in the female. 1516 indicates that $l_{\mathrm{III}}$ is to the right of $D^{\prime} ; 2424$, to the left if the individual was a single crossover. But the distance $D^{\prime} S_{s}$, here involved, is known to be long enough so that double crossovers sometimes occur in it. In 2571 the distance involved is $D^{\prime} p^{p}$, which is too short for a double crossover, therefore $l_{\mathrm{mI}}$ is to the right of $D^{\prime}$. The position of $l_{\mathrm{III}}$ being thus obtained, the not- $D^{\prime}$ produced by 2424 must have been a double crossover.

The next problem is: How far from Dichæt is the lethal locus? The mating is always-

$$
\frac{D^{\prime}}{l_{\mathrm{III}}} \times \frac{D^{\prime}}{l_{\mathrm{III}}}
$$

There being no crossing over in the male, the sperm are of two kinds only- $D^{\prime}$ and $l_{11}$. The non-crossover eggs are of the same 
constitution, but there are also the crossover eggs, $D^{\prime} l_{\mathrm{III}}$, and + . If we let the non-crossovers be to the crossovers as $x: y$, the result of the mating will be:

$$
x\left\{\begin{array} { l } 
{ \frac { D ^ { \prime } } { D ^ { \prime } } = \text { dies. } } \\
{ \frac { D ^ { \prime } } { l _ { \mathrm { III } } } = \mathrm { D } ^ { \prime } . } \\
{ \frac { l _ { \mathrm { III } } } { D ^ { \prime } } = \mathrm { D } ^ { \prime } . } \\
{ \frac { l _ { \mathrm { III } } } { l _ { \mathrm { III } } } = \text { dies. } }
\end{array} \quad y \left\{\begin{array}{l}
\frac{D^{\prime} l_{\mathrm{III}}}{D^{\prime}}=\text { dies. } \\
\frac{D^{\prime} l_{\mathrm{III}}}{l_{\mathrm{III}}}=\text { dies. } \\
\frac{+}{D^{\prime}}=\mathrm{D}^{\prime} . \\
\frac{+}{l_{\mathrm{III}}}=\text { not-D } .
\end{array}\right.\right.
$$

The result then is:

$$
\begin{aligned}
& \qquad x+y=\mathrm{D}^{\prime} \quad y=\text { not- } \mathrm{D}^{\prime} \\
& \text { Per cent crossovers }=\frac{100 y}{x+y}=\frac{200\left(\text { not- }-\mathrm{D}^{\prime}\right)}{\mathrm{D}^{\prime}+\text { not- } \overline{\mathrm{D}}^{\prime}}
\end{aligned}
$$

In the present case this formula gives the crossover percentage as 0.29 . Lethal III is, then, located 0.29 to the right of Dichæt.

Another lethal of the same sort as the one just described appeared in culture 1546. This culture belonged to the sixth generation of the same line in which the first lethal was found, and was descended from a sister pair (1213) to 1264, the first culture in which that lethal appeared. Since the two lethals are certainly distinct, as will appear below, this relationship is to be regarded only as a coincidence. Three cultures of this strain were made-1546 and two daughter pairs. The result was 154 Dichæts and 1 not-Dichæt. The 1 not-Dichæt was from culture 1681. The Dichæts from this culture show both parents to have had the constitution

$$
\frac{D^{\prime}}{s_{e} l^{\mathrm{III}} s_{s} e_{s} r_{o}}
$$

The not-Dichæt individual was spineless, sooty, rough. This indicates that the lethal was to the left of Dichæt; otherwise the egg in question must have resulted from a sepia Dichæt spineless triple crossover, which is a very rare occurrence. By the method outlined above it may be calculated that the lethal gives 1.29 per cent of crossovers with Dichæt.

That these two lethals are distinct is indicated by the following culture, 1915. The female of this mating came from culture 1791, which gave 31 Dichæts and no not-Dichæts. 1791 was an $\mathrm{F}_{2}$ from a cross involving 1419 of the 1264 line, and thus its lethal must be supposed to be that of 1264 . The male of the test bottle 1915 was from 1681 of the second lethal strain. Therefore, if the two lethals are the same, 1915 should have given few or no not-Dichæts; if they are different it should have given 2 Dichæts to 1 not-Dichæt. The actual 
result was 51 Dichæts to 30 not-Dichrts. Evidently, then, the two lethals are distinct, as was previously indicated by the fact that they are probably on different sides of Dichret.

It seemed possible at first that one or both of these lethals might be due to a breaking up of the Dichæt factor, whereby its lethal effect had been separated from the effect it produces on the soma of a heterozygous fly. This hypothesis is negatived by two considerations: (1) both lethals have been shown to occupy loci different from that for Dichæt; (2) the lethal effect of Dichxt is not allelomorphic to that of these factors, since a fly with Dichæt in one chromosome and either of the lethals in its mate does not die.

\section{EXTENDED.}

In culture 1379 , of the crossbred plus series, there appeared several flies intermediate in appearance between Dichæt and the normal. These flies had the bristles of the normal flies (including the anterior post-alars, always reduced or absent in Dichrts), but had their wings spread out to a greater or less extent. These individuals were tested, and were found to have a dominant factor, responsible for the extended wing character. The character has been called "Extended" (see plate 1, fig. 1). It occasionally overlaps the normal, and is therefore not favorable for linkage experiments. It is, however, sufficiently uniform in appearance to make it possible to work out its inheritance with certainty. The gene is found to be an allelomorph of Dichæt, and is designated $\mathrm{D}^{\mathrm{e}}$. Like Dichæt, it is lethal when homozygous; and the flies with Dichrt in one chromosome and Extended in the other also die. These conclusions are based on the following results:

Preliminary experiments involving speck (chromosome II) and various characters in chromosome III showed that Extended crosses over freely from speck in the male, but gives apparently no crossing over in the male with sepia, spineless, or rough. These data are not very satisfactory, owing to the fact that some of the Extended flies are very similar in appearance to the not-Extended, and there is too great an opportunity for being influenced by the other characters of the flies when making the separation. However, no crossovers were discovered among 308 flies.

When tests were made of heterozygous females, there was found to be a slight excess of not-Extended offspring, presumably due to incorrect classification. The proportion of crossorers, based on Extended offspring only, was $\frac{13}{105}=12.4$ per cent for sepia Extended and $\frac{11}{144}=7.6$ per cent for Extended spineless. In one experiment in which all three of these factors were observed at once, the result shown in table 23 was obtained. 
It is evident from these data that Extended is between sepia and spineless, some distance from either. It is, then, in the same general region as Dichæt.

The lethal effect of Extended has been tested in two ways. Matings of Extended by Extended gave 116 Extended to 94 normals. If homozygous Extended is viable the result should be $3: 1$; if it dies the result should be $2: 1$. In fact, it was nearer $1: 1$. This result is probably due to the overlapping phenomenon, resulting in the classification of some Extended flies as normal. It is suggestive of a $2: 1$ ratio, however. More conclusive data was obtained by mating heterozygous Extended to Dichæt flies heterozygous for lethal III (see above), and inbreeding the Extended offspring. If Extended is lethal when homozygous, these flies should produce only Extended offspring, but these should all be heterozygous. They should, in fact, breed exactly like the true-breeding race of Dichæts described above. This is actually the case. Such a stock has now been kept for four months, and is still made up almost entirely of evidently Extended flies; but tests show them to be only heterozygous for the character.

TABLE 23.

\begin{tabular}{|c|c|c|c|c|c|c|c|c|}
\hline \multicolumn{9}{|c|}{$\frac{D^{e}}{s_{e} s_{s} \odot} X s_{t} s_{s} \sigma^{\top}$} \\
\hline$D^{e}$ & $s_{e} s_{s}$ & $s_{s}$ & $s_{s} D^{e}$ & $D^{e_{s_{s}}}$ & $s_{e}$ & $N$ & $s_{e} D^{e} s_{s}$ & Total. \\
\hline 39 & 37 & 3 & 3 & 6 & 10 & 0 & 1 & 99 \\
\hline
\end{tabular}

The mating of Dichæt $\times$ Extended (or vice versa) gave the following result: Dichæt, 99; Extended, 69; normal, 102; total, 270 . If we suppose some of the flies classified as "normal" to be in reality Extended, this result approximates to the $1: 1: 1$ expected if DichætExtended fiies die. The fact that the Dichrts are only about a third of the total shows that half the Dichæt gametes have been eliminated somehow. One of the Dichæts and a number (4 individual matings and 2 mass cultures) of the Extendeds have been tested, and neither sort has produced the other. It is, then, safe to conclude that DichrtExtended flies die.

Culture 1379, in which Extended first appeared, was made up by mating together two 8-bristled flies, the male from 1145, the female from 1253. The latter culture gave among other offspring 5 sevens and 2 eights. The other eight, in 1356, behaved normally, as did one of the sevens (in 1357). Culture 1145, however, gave no seven and only the single eight. Since 1379 gave a result indicating that one parent was Extended instead of 8-bristled Dichæt, it seems probable that the male parent, from 1145, was the mutant. In either case, the Extended parent was produced by mating a 7-bristled Dichæt 
female to a 6 -bristled Dichæt male, both parents being from the crossbred plus selection series.

It follows from the data presented above that Extended is an allelomorph of Dichrt intermediate between Dichæt and its normal allelomorph in its somatic effect, and that it arose in a fly heterozygous for these two factors. It is, then, the kind of thing one would expect contamination of allelomorphs to produce. On the other hand, it seems at least equally possible to suppose that it arose as a mutation of one or the other allelomorph, without the presence of the other or the one having had any influence on the event. In any case, the process must be an extremely rare one, for it has been detected only once, in spite of the very large number of offspring of heterozygous Dichæt flies that have been observed and bred.

Since the Extended flies have more bristles than Dichrts, it may be supposed that the fact that the former arose in a plus-selected series is significant. Such a supposition has actually been made by Castle (Castle and Phillips, 1914, etc.) with regard to a similar case in hooded rats. As has been pointed out by MacDowell (1916), a mutation in the direction in which selection is being made has a very much better chance of being discovered than has one in the opposite direction. Moreover, these mutations have been demonstrated only in an extremely small number of cases; and a very elementary knowledge of the theory of probability will suffice to convince one that a considerable number of cases must be established before one can conclude that mutations are more likely to occur in one direction than in another. No argument based on one or two cases, however well established those cases may be, can carry any conviction.

\section{"DICHÆTE INTERMEDIATE."}

The Star Dichæt stock in the Columbia laboratory was found to have in it some flies that were indistinguishable from Extended. It seemed possible that these flies were due to an independent oceurrence of the Extended mutation. Since the Star Dichæt stock is kept by mating (Star) Dichæt flies together in each generation, the mutation responsible for these "intermediates" must either have occurred in a Dichæt fly (as did the Extended mutation), or have been in the stock since it was made up. The fact that Dichrts are mated together in continuing the stock seemed, however, to show that the character was not true Extended, since, as we have seen above, Dichæt-Extended flies always die. But the possibility remained that "intermediate" was another non-lethal allelomorph of Dichæt. Accordingly, tests were made as follows:

Matings of Dichæt by Dichæt gave some intermediates, showing that the continuance of the character in the stock was not dependent on the use of non-virgin females, and proving that the character was not Extended. 
Matings of intermediates by intermediates gave both intermediates and normals, showing that the character was either dominant or irregular in appearance.

Matings of intermediate to specks and to black purples of other stocks gave only normals, showing the character to be recessive.

Mating together the $F_{1}$ normals from the last type of matings gave a few intermediates; but these were in no case speck or black or purple. This is the usual behavior of a second-chromosome recessive, due to no crossing over in the $\mathrm{F}_{1}$ male. Hence "intermediate" is a recessive character, and lying in the second chromosome. Its occurrence in the Star Dichæt must have been only a coincidence, and can have had nothing to do with the presence of Dichrt in that stock. The difference between this character and Extended is a striking illustration of the danger of arguments as to the identity of characters based on similarity of appearance.

\section{NOT-DICHÆTS FROM SELECTED LINES.}

As has already been pointed out, Dichæt flies almost always have fewer bristles than have normals. All Dichæts are heterozygous for the normal allelomorph. Therefore, in such an experiment as this one, in which Dichæts are repeatedly mated together, one obtains normal flies the not-Dichrt genes in which have been associated with Dichæt genes for many generations. The experiment is, then, suited for a study of the question as to whether or not factors "contaminate" their allelomorphs. If this contamination occurs, one might expect the not-Dichrt flies to show a tendency to have fewer bristles than they normally have, and the Dichæts to have more. That Dichæts tend to increase in bristle number is very improbable. The stock has now been kept, always of necessity in heterozygous condition, for more than 40 generations. There is no evidence that any progressive change has occurred, though no selection has been used in keeping the stock cultures. The modal class at present ( 5 bristles) is actually lower than the class (6) of the original mutant. ${ }^{1}$

There are some data regarding the bristles of the not-Dichæts produced by selected Dichæts. Counts of these bristles have been taken only occasionally (see table 24), but whenever a bristle number other than 8 has been observed in such flies it has been noted on the record sheet. Examination of these notes shows that in the minus-selected series there are several records of 6 and 7 bristled not-Dichæts, but none of numbers higher than 8 . In the plus selected lines there are a number of records of nines and tens, but no sixes and only 1 seven (from 1190, an $\mathrm{F}_{6}$ of the crossbred plus series). The complete counts taken of bristle numbers are given in table 24 .

\footnotetext{
'It may be pointed out that the familiar yellow mouse and several similar cases in Drosophila afford evidence of the same sort against contamination.
} 
There is no evidence for contamination. With the one exception noted above, all the variations are in the direction for which the Dichæts were being selected. On the multiple-fact or view one would expect this result, since it would seem likely that any modifier would usually affect Dichæts and not-Dichæts in the same direction. The one exception, a 7 from 1190 of the crossbred plus series, is scarcely surprising on this hypothesis, in view of the facts that unselected notDichæt races may produce sevens (see table 2), and that 1190 was probably not homozygous for a large number of plus modifiers. Since this individual was not tested, it would perhaps be futile to argue the case further.

TABLE 24.

\begin{tabular}{|c|c|c|c|c|c|c|c|}
\hline \multirow{2}{*}{ Culture. } & \multirow{2}{*}{ Series. } & \multirow{2}{*}{$\begin{array}{c}\text { Genera- } \\
\text { tion. }\end{array}$} & \multicolumn{5}{|c|}{ Bristle Nos. } \\
\hline & & & 6 & 7 & 8 & 9 & 10 \\
\hline 1277 & 864 plus. & 7 & . & . & 57 & & \\
\hline 1285 & Crossbred plus. & 7 & .. & .. & 35 & 1 & $\because$ \\
\hline 1357 & Crossbred plus..... & 8 & .. & .. & 33 & 4 & .. \\
\hline 1810 & 864 plus...... & 10 & .. & .. & 51 & .. & .. \\
\hline 1811 & 1002 plus.......... & 7 & .. & .. & 16 & .. & .. \\
\hline 1268 & Crossbred minus... & 6 & .. & $\therefore$ & 13 & $\therefore$ & $\therefore$ \\
\hline 1273 & Crossbred minus... & 7 & .. & .. & 33 & .. & .. \\
\hline 1878 & Crossbred minus... & 10 & $\therefore$ & .. & 15 & .. & $\therefore$ \\
\hline 1879 & Crossbred minus.... & 10 & .. & .. & 20 & .. & .. \\
\hline 1881 & Crossbred minus.... & 10 & .. & .. & 23 & .. & .. \\
\hline 1882 & Crossbred minus.... & 10 & 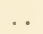 & 1 & 31 & .. & .. \\
\hline 1892 & Crossbred minus.... & 10 & .. & .. & 10 & .. & .. \\
\hline $19 S 6$ & 1331 (speek) minus. & 5 & .. & .. & 12 & .. & .. \\
\hline 1996 & 1331 (speek) minus. & 5 & 1 & .. & 34 & .. & .. \\
\hline 2015 & Crossbred minus.... & 11 & .. & .. & 88 & .. & .. \\
\hline
\end{tabular}

It may be noted here that in the Star Dichrt stock referred to above (p. 31) there were found to be numerous not-Dichæts with 9 and 10 bristles. Unfortunately, no counts were made on these flies, and the nature of the extra bristles was not determined. The stock has sinee been "purified," to rid it of certain other mutations, and the extrabristled flies, formerly plentiful, have now disappeared. This stock, as stated above, was continued by mating together (Star) Dichret flies, without regard to bristle number. These extra-bristled notDichæts therefore furnish evidence of the same type as that just discussed, except that the race was not selected for bristle number. 


\section{GENERAL DISCUSSION.}

THE SELECTION PROBLEM: QUESTIONS AT ISSUE.

It appears to the writer that the three questions below are the chief ones at issue in the discussion of the selection problem:

1. Does selection use germinal differences already present, or differences that arise during the experiment, or both?

2. In case it uses new differences, does it cause them to occur more frequently, and does it influence their direction?

3. Are differences, already present or arising de novo, more likely to occur in the locus of the gene under observation, or in other loci?

It is not, I think, questioned by any one that selection may effect either gradual or sudden change in the mean character of mixed races, or that it may even, occasionally, produce such an effect in pure races if a mutation in the desired direction happens to occur.

1. Does selection use germinal differences that are already present, or differences that arise during the experiment?

Everyone who has bred animals or plants is familiar with the fact that different strains, even when rather closely related, differ in all sorts of minor points-size, proportions of organs, shade of color, resistance to disease, fertility, temperament, rate and habit of growthin fact, in almost any respect that one investigates. This can only mean that such strains differ genetically; and since the kinds of differences are usually so numerous, they probably usually have many genetic differences- $i$. $e$, they differ in respect to many factors. In any race not normally self-fertilizing or closely inbred, crosses between individuals of different constitution must then be frequent. And such crosses must, on the assumption that the original differences were Mendelian, lead to the production of a population more or less heterozygous for factors that produce minor effects on all sorts of characters. The assumption that the differences are Mendelian rests on the observed facts, (1) that demonstrably Mendelian factors may produce effects on practically any kind of character studied, and effects of practically any observable degree; and (2) that non-Mendelian inheritance has never been demonstrated, except for a few cases of plastic characters in plants and cases of infectious diseases. ${ }^{1}$ Other kinds of inheritance may exist; but the available data indicate that they must be extremely rare. Therefore the chances are that any observed difference between two strains is Mendelian.

If these conclusions be accepted, it follows that any strain not very closely inbred is likely to be heterozygous for factors influencing many characters. Selection for these characters will then be effective in isolating favorable combinations of such "modifying factors."

\footnotetext{
${ }^{1}$ One may refuse to call these cases of inheritance if he chooses to define that term so as to exclude them.
} 
Mendelian differences are still arising by mutation and may arise in a selection experiment as well as anywhere else; and those that arise in such an experiment are as likely to affect the character under observation as are any Mendelian differences taken at random. It is therefore probable that selection sometimes makes use of variations that arise during the course of the experiment, or, rather, that variations which may be available do arise.

The question is, what is the relative frequency of the two kinds of available factor differences - those already present and those that arise de novo? The answer is found by investigation of the data on selection in inbred lines and in crossbred lines. In closely inbred strains there are not likely to be many factor differences present when selection is begun, while in crossbred lines these differences are likely to be numerous.

That selection is usually effective in crossbred lines is a well-known fact, demonstrated many times with many different organisms. Not many experiments have been carried out on closely inbred material, but those of Johannsen (1903), MacDowell (1917), and the present paper (p. 11) show that selection may be without effect in such lines. In two of these cases selection was effective until the lines became highly inbred. But mutations influencing the characters under observation have been obtained in the selection experiments of Castle and Phillips (1914), Morgan (Morgan, Sturtevant, Muller, and Bridges, 1915, p. 205), Lutz (1911), and those reported in this paper (p. 31). ${ }^{1}$

Apparently, then, selection produces its effects chiefly through isolation of factors already present, but occasionally available mutations do arise during the course of the experiment.

2. Does selection cause mutations, or influence their direction?

The usual selection experiment consists in breeding from individuals that are extreme in some respect. This extreme character may be environmental in origin, or it may be caused by germinal differences. In the first case, no geneticist is likely seriously to maintain that selection will have any effect whatever. In case the extreme character is germinal in origin, selection will of course be effective in eliminating certain genetic types. Moreover, given a combination of genes that produce the character in a certain degree, we are evidently in a better position to reach a further stage than if we have the character less well developed. For how long a tail will be when it gains an inch evidently depends on how long it was before it gained that inch. But it seems incomprehensible that selection of individuals of a constitution favor-

\footnotetext{
${ }^{1}$ Evidence derived from forms that reproduce ascxually is also available in studying this question, for such reproduction commonly prevents recombination, and therefore gives results comparable with those obtained from homozygous strains. Some of the evidence obtained from studies on asexually produced Protozoa (e.g., Calkins and Gregory, 1913; Jennings, 1916; Middleton, 1915) has shown that selection may be very successful in changing such forms. But it is very doubtful if these animals are comparable with the Metazon in the method of distribution of their chromatin. It scems not improbable that in some cases recombination may here be possible in asexual reproduction.
} 
able to the development of a given character can make more likely the occurrence of factorial variations affecting that character, or variations affecting it in a given direction. As a matter of fact, there is no evidence for such a conclusion. The occurrence of mutations is ordinarily such an extremely rare phenomenon that it would be very difficult to obtain statistically significant data in the matter. Moreover, when one is selecting for a character, one is examining his animals or plants for that character with unusual care, so that any mutations in that character are very likely to be observed and tested, provided they are in the direction in which selection is being carried out. It follows from these considerations that extremely careful controls are required before any data on these questions can have any significance.

3. Are variations more likely to occur in the locus of the gene under observation, or in other loci?

In Drosophila over 25 different and independent mutant factors affect the color of the eye. In mice there are 7 or more independent factors affecting coat-color. According to Little (1915) there are 2 and probably 3 independently segregating factors that affect spotting in these animals. There are at least 14 and probably more definite genes (in different loci) that affect bristle number in Drosophila, not counting the "modifying factors" studied by MacDowell and the writer.

In view of these and many similar facts, it is certain that changes in a given character may be brought about by changes in many different parts of the germ-plasm. If selection of a given mutant race, say hooded rats or Dichæt Drosophila, is likely to cause or to isolate mutations in the gene that differentiates that race from the normal type (i. e., the hooded factor or the Dichæt factor) rather than in any other factors, it follows that mutant allelomorphs must be more variable than "normal" ones. For, by analogy with mice, hooded rats are homozygous for the normal allelomorphs of several possible factors affecting spotting; and Dichrt flies are certainly homozygous for the normal allelomorphs of at least 13 mutant factors that affect bristle number. It may be true that mutant factors are on the average more variable than their normal allelomorphs; but no evidence to that effect is at hand; and owing to the great difficulty of statistical treatment of the frequency of mutations alluded to above, such evidence will be very difficult to obtain. ${ }^{1}$

In the absence of such evidence, it is more probable that variations will appear in other factors, since there are many of them to vary, but commonly only one that is responsible for the difference under observation. That changes of the one factor itself may occur in selection experiments, however, has been shown by Castle (Castle and Wright, 1916) and the writer (p. 31). It does not follow that selection has caused these variations or that they are more likely to occur than are variations in other factors.

\footnotetext{
${ }^{1}$ Evidence has been obtained by Emerson (1917), who used unusually favorable material, that shows clearly that different allelomorphs may at times differ greatly in their mutability.
} 


\section{CONTAMINATION OF ALLELOMORPHS.}

When two races that differ in quantitative characters are crossed, it is frequently observed that $F_{1}$ is fairly uniform, and that $F_{2}$ shows an increase in variability together with the production of forms intermediate between the parent races and often different from the $F_{1}$. There are two current methods of accounting for these cases:

(1) The two races are assumed to have differed in a number of Mendelian factors affecting the character in question. The observed result is then explained as due to the recombinations of these factors.

(2) The two races are assumed to have differed in only one factor affecting the character in question, and the new types observed in $F_{1}$ are supposed to be due to "contamination" in the $F_{1}$ hybrid, that is, allelomorphs present in the heterozygote are supposed to have influenced each other, so that they do not come out unchanged.

The fundamental principle of the first explanation-that more than one factor may influence the same character-is admitted by all Mendelians. But many of the adherents of that explanation are unwilling to admit that "contamination of allelomorphs" has ever been experimentally demonstrated. Let us then examine the evidence that is brought forward in support of that assumption.

The following quotations are the chief ones bearing on the question that I have been able to find in recent literature:

"The currently accepted explanation (of size inheritance), which its supporters choose to call 'Mendelian,' rests upon the idea of gametic purity' in Mendelian crosses. It assumes that Mendelian unit-characters are unchangeable and unvarying, and that when they seem to vary this is due to a modifying action of other unit-characters (or factors)... The idea of unit-character constancy is a pure assumption. In numerous cases initcharacter inconstancy has been clearly shown, as in the plumage and toe characters of poultry according to the observations of Bateson and Davenport, and the coat-characters and toe-characters of guinea-pigs in my own observations. Unit-character inconstancy is the rule rather than the exception." (Castle, 1916b, p. 209.)

"... I have shown in numerous specific cases that when wnlike gametes are brought together in a zygote they mutually influence each other; they partially blend, so that after separation they are less different than they were before. The fact remains to be accounted for that partial blending does occur (1) when polydactyl guinea-pigs are crossed with normals (Castle, 1906); (2) when long-haired guinea-pigs are crossed with short-haired ones (Castle and Forbes, 1906); and (3) when spotted guinea-pigs or rats are crossed with those not spotted (MacCurly and Castle, 1907). Darenport has furnished numerous instances of the same thing in poultry; indeed, he has shown that "imperfection of dominance" and of segregation are the rule rather than the exception in Mendelian crosses in poultry:" (Castle, 1916d, p. 253.) ". . . The English unit-character had changed quantitatively in transmission from father to son. This seems to us conclusive evidence against the idea of unit-character constancy, or 'gametic purity.'" (Castle and Hadley, 1915.)

". . We are often puzzled by the failure of a parental type to reappear in its completeness after a cross - the merino sheep or the fantail pigcon, for 
example. These exceptions may still be plausibly ascribed to the interference of a multitude of factors, a suggestion not easy to disprove; though it seems to me equally likely that segregation has been in reality imperfect." (Bateson, 1914.)

Fractionation is referred to by Bateson in this same paper as probably due to imperfect segregation. Illustrations are Dutch rabbit and Picotee and other sweet peas. (See p. 298.)

"Accordingly we seem limited to the conclusion that a slowly blending gene is involved in the cross between early flowering and late flowering peas, that the blending after one generation of heterozygosis may be small in amount, but after three generations it is in the majority of cases practically complete, so that the commonest 'constant' class in the entire hybrid population is one strictly intermediate between the modes of the parental varieties. This interpretation is entirely in harmony with the observed modification through crossing of many Mendelizing characters, as observed by Davenport, Bateson, and many others in poultry, guinea-pigs, swine, and other animals, as well as in plants." (Castle, 1916b, p. 215.)

Hayes (1917) states on the basis of his experiments with variegated maize:

". . . One might conclude that certain heterozygous combinations produce germinal instability which exhibits itself either as imperfect segregation, gametic contamination, or sporophytic variation."

In these quotations the following cases have been cited as evidence in favor of contamination, and therefore calling for investigation:

1. Polydactyl guinea-pigs (Castle, 1906).

2. Long-haired guinea-pigs (Castle and Forbes, 1906).

3. Spotted guinea-pigs and rats (MacCurdy and Castle, 1907).

4. English rabbits (Castle and Hadley, 1915).

5. Poultry, plumage and toe characters (Bateson and Davenport).

6. Merino sheep.

7. Fantail pigeons.

8. Dutch rabbits.

9. Picotee and other types of sweet peas.

10. Flowering time in peas (Hoshino, 1915).

11. Unspecified case in swine.

12. Variegated pericarp in maize (Hayes, 1917).

Before we can discuss some of these cases intelligently it is necessary that we make sure what Castle means by the terms "gametic purity" and "unit-character." Unless these terms are understood in such a way as to eliminate from consideration the idea of recombination of independent factors there is, of course, nothing to discuss. If by gametic impurity or inconstancy of unit-characters is meant that recombination of modifying factors occurs, the existence of such phenomena must be granted at once- this is, in fact, the main contention of the school of "pure line" advocates or "mutationists." I think the two following quotations from Castle are sufficient to show that there need be no disagreement on the question of defining these terms:

"What we want to get at, if possible, is the objective difference between one germ-cell and another, as evidenced by its effect upon the zygote, and it is

\footnotetext{
${ }^{1}$ The rough-coated guinea-pig was formerly cited (e.g., Castle and Phillips, 1914), but is now never used. This is because Wright (Castle and Wright, 1916) has shown the results to be due to multiple factors.
} 
the constancy or inconstancy of these objective differences that I am discussing. If these are quantitatively changeable from generation to generation, then change in the variability of the zygote composing a generation might arise without factorial recombinations."' (Castle, 1914a.)

"The head, the hand, the stomach, stomach-digestion, these are not unitcharacters so far as any one knows. But if a race without hands were to arise and this should Mendelize in crosses with normal races, then we should speak of a unit-character or unit-factor for 'hands,' loss of which or variation in which had produced the abnormal race. But in so doing we should refer not to the hand as an anatomical part of the body nor to the thousand and one factors concerned in its production, but merely to one hypotheticrl factor to which we assign the failure of the hand to develop in a particular case. It is immaterial whether we call this a unit-character or unit-factor or use both terms interchangeably . . . ." (Castle, 1916b, p. 100.)

\section{Polydactyl Guinea-Pigs.}

The most extensive data on this case are apparently in the paper (Castle, 1906) cited in the quotation already given. The extra-toe character was at first irregular in appearance, but was improved by selection. In five generations, without very close inbreeding, a practically uniform race was obtained. When crosses to normal were made, the $F_{1}$ results varied from nearly all normal to nearly all polydactylous. $\mathrm{F}_{2}$ contained both normal and extra-toed individuals. It is pointed out by Castle in this paper that the results are very similar to those obtained by Bateson from polydactylous fowls. Bateson's comment on that case is given below.

In the absence of any definite data regarding $\mathrm{F}_{2}$ counts, the case as reported is entirely explicable on the multiple-factor view. Castle himself said of it, five years after the publication of the above paper:

"An alternative explanation is possible, viz., that the development of the fourth toe depends upon the inheritance of several independent factors, and that the more of these there are present, the better will the structure be developed. The correctness of such an interpretation must be tested by further investigation." (Castle, 1911, p. 101, footnote.)

So far as I have discovered, such further investigations have not yet been reported, although five years later this case is listed as No. 1 among those that demonstrate contamination of allelomorphs.

\section{Long-haired Guinea-Pigs.}

The reference given for this case (Castle and Forbes, 1906) seems to contain the most recent and complete data regarding it.

Angora guinea,-pigs appeared in a short-haired stock, apparently as segregated recessives. On crossing to short and extracting, there were produced some animals of intermediate hair-length, and some unusual ratios. But similar intermediates appeared in another strain of shorts, apparently uncrossed with angoras, thus making it highly probable that we are dealing here with a factor already present in the

\footnotetext{
IItalics mine.
} 
race, and not produced by the cross of angora $\times$ short. The unusual ratios are based on quite small numbers, and the authors admit that there are difficulties in separation of the three classes, apparently due to overlapping. Moreover, we are given the results only in total, not from each mating separately.

Castle himself has said of this case: " . . a single unit-character is concerned. Crosses in such cases involve no necessary change in the race, but only the continuance within it of two sharply alternative conditions." (Castle, 1911, p. 39.)

\section{Spotted Guinea-Pigs and Rats.}

The reference given for these cases is MacCurdy and Castle (1907). I am unable to find in that paper any evidence regarding guinea-pigs that bears on the question of contamination. Nothing but selection experiments are reported. There is, so far as I am aware, no evidence of significance in this connection in the more recent literature on spotting in guinea-pigs.

The evidence referred to from rats is apparently that obtained from crosses between hooded and Irish races. Hooded rats extracted from such crosses had more extensive colored areas than the uncrossed hooded rats. The data given by Castle and Phillips (1914) and analyzed by MacDowell (1916) show that this is true only when the hooded race is a "minus" one. The "plus" hooded race becomes less pigmented when crossed to Irish (or to self). MacDowell has shown that these results conform very closely to the expectations based on the multiple-factor view.

The later evidence on the case of the hooded rat is discussed elsewhere in this paper.

\section{ENGLish RabBits.}

The data for this case are contained in two papers (Castle and Hadley, 1915a, 1915b), in each of which the full presentation is made. The spotting of the English rabbit is a dominant character and is somewhat variable. A single heterozygous male, of the grade designated 2, was mated to a number of Belgian hares. 187 English young were produced, of mean grade 2.43, and of these $F_{1}$ English, a buck of grade 3.75 (only one $F_{1}$ English was of higher grade), was then mated to the same Belgian hare females. 189 English young, of mean grade 2.92 , were produced.

This case presents no difficulties for the multiple-factor view, since no evidence is given that indicates the original English buck to have been homozygous for all modifying factors, or that prevents us from supposing the Belgian mother of the $\mathrm{F}_{1}$ buck to have transmitted more plus modifiers to him than were present in his father. Under the circumstances, it would have been very surprising if the two lots of young had been of the same mean grade. 


\section{Plumage and Toe Characters in Poultry.}

We are referred to the observations of Bateson and 1)avenport for these cases. In one instance it is stated that Davenport has shown that "imperfection of dominance" and of segregation are the rule in poultry. The question of imperfection of dominance is not apropos in this connection. As Castle has said, regarding another case:

"... . if black is crossed with brown, the crossbreds are apt to develop in their coats more brown pigment granules than do homozygous or pure blacks. Nevertheless, we have no reason to question the entire purity of the gametes, both dominant and recessive, formed by such cross-bred black animals. It is the dominance, not the segregation, which is imperfect." (Castle, 1911, p. 91.)

That $F_{1}$ results do not bear on the question has been shown by Bateson (1909), who says with regard to polydactylous fowls:

"It might be pointed out that when, as in these examples, the abnormal result is clearly perceptible in $F_{1}$, no question arises as to the occurrence of an imperfect segregation. The peculiarity is evidently zygotic, and is caused either by some feature of zygotic organization, or by the influence of extermal circumstances." (Bateson, 1909, p. 251.)

Moreover, in any case involving irregularities in dominance, imperfect segregation in crosses between different breeds would be very difficult to demonstrate.

\section{Merino Sheep.}

No reference to the data in this case are given. I have been unable to discover anything more definite than a few general statements by practical breeders regarding the effects of crossing Merinos.

Bateson admits, in the passage quoted above, that this and the next case "may be ascribed to the interference of a multitude of factors."

\section{Fantail Pigeoxs.}

This case has been studied by Morgan (Morgan, Sturtevant, Muller, and Bridges, 1915, p. 186). The fantail type did not reappear in the comparatively small $\mathrm{F}_{2}$ generation, but individuals not far from the fantail were obtained; and when the $F_{1}$ hybrids were mated to fantails, several of the offspring fell within the range of the fantail race. Bateson's "failure of a parental type to reappear in its completeness after a cross" is, then, scarcely applicable to this case.

8 and 9. Dutcin Rabits and Cases in Sweet Peas. Fractionation.

These are the specific cases cited as illustrations of Bateson's theory of "fractionation" or "subtraction stages," of which he states that "it is to be inferred that these fractional degradations are the consequences of irregularities in segregation." In the case of the sweet pea, Bateson has pointed out that white flowers and the extreme dark 
flowers of the deep purple Black Prince were among the earliest variations to appear, while the intermediate forms have arisen later, as he suggests by fractionation. It would seem to follow that they have arisen in heterozygous forms, for otherwise the fact that the larger variants appeared first would be of no significance. There is, I think, no evidence to show that the later variations did actually arise in heterozygous forms, either in sweet peas or in rabbits. These factors are all inherited separately, and this fact would seem to rule them out of consideration if one adopts the chromosome theory of inheritance or if one appeals to multiple allelomorphs as evidence in favor of the variability of genes. In short, we have no evidence regarding the origin of these forms, and their present behavior seems to indicate that they are not due to fractionation. The only evidence in favor of such a hypothesis is the somatic appearance of the characters.

\section{Flowering Time in Peas.}

Castle (1916a, p. 324) has summarized this case as follows:

"Hoshino (1) recognizes that gametic contamination results from crossing early and late flowering varieties; (2) recognizes also that variation may occur among the cross-bred families, as well as in different pure lines of the uncrossed races, as regards the 'quality,' value, or potency of the same gene; (3) although Hoshino does not refer to the fact, his observations show clearly that genetic variation of a gradual or fluctuating sort occurs in at least one of the varieties which he crossed.

". . What I want to suggest is that in these several agencies we have a sufficient explanation of the variation observed in Hoshino's $\mathbf{F}_{2}, \mathbf{F}_{3}$, and $\mathbf{F}_{4}$ generations, without invoking a two-factor hypothesis (as Hoshino has done), one factor being enough."

Castle's argument is that a difference in one pair of genes is sufficient to account for the result, if contamination be assumed; and that one difference is a simpler assumption than two. I have argued here that such an assumption is not simpler, unless we can find positive evidence that contamination ever occurs. In the present case, then, we must turn to the evidence that led Hoshino to suppose contamination to have occurred.

Hoshino crossed an early-flowering pea and a late-flowering one. The $F_{1}$ was nearly as late as the late parent; $F_{2}$, obtained by selffertilizing $F_{1}$, approximated fairly closely to 3 late : 1 early, but the two classes were somewhat more variable than the corresponding parent varieties, and apparently overlapped slightly. Hoshino selffertilized 236 of these $\mathrm{F}_{2}$ plants and obtained 46 families that he classified as constant, $i$. e., supposedly homozygous. This is a fair approximation to the 1 in 4 expected if two pairs of genes are responsible for the result. Hoshino shows that two pairs of genes will, in fact, account for most of the results obtained. There are certain facts not thus accounted for, but Hoshino shows (p. 265) that "secondary" 
modifiers ( $i$ e.e, modifiers producing only small effects) will account for all these facts, with a single exception. Three families were obtained from $\mathrm{F}_{2}$ plants that must, on the two-factor view, have been of the same constitution. These plants were heterozygous for one pair of genes only. They produced, in $\mathrm{F}_{4}$, the same type of later constant (homozygous) families, but differed slightly in the flowering times of the earlier constant families produced. According to $\mathrm{Ho}_{\mathrm{O}}$ shino's view, if the earlier types differed the later ones should have differed in the same direction, because they must have received the same "secondary modifiers." This objection is not valid, for specific modifiers that act only in the presence of certain other genes are well known (see especially Bridges, 1916), and are sufficient to account for the differences observed. This argument is the only one that Hoshino gives to support his conclusion that contamination must have occurred. We must then conclude that the case does not furnish positive evidence for contamination, since it is explicable without recourse to that hypothesis. ${ }^{1}$

\section{Unspecified Case in Swine.}

This case is cited by Castle $(1916 b, p .215)$, but no references or authorities are given. It appears, however, from the legend under figure 93 (opposite p. 139) that the belted character is the one referred to. The only data bearing on this case that I have found are presented by Spillman (1907), and consist of information supplied largely by practical swine-breeders. Spillman himself interpreted the case as one in which two factor-pairs are involved. The data also suggest the possibility that we are dealing with a case of "imperfect dominance" similar to those in poultry. At best, the data are meager and indefinite.

12. Variegated Pericarp in Maize.

The paper of Hayes (1917) referred to above should be studied in connection with those of Emerson, particularly his full paper (Emerson, 1917), dealing with the same character. These two workers have shown that there is a remarkable series of multiple allelomorphs in this case, and Emerson has shown very clearly that some of these allelomorphs mutate quite frequently-the only established instance of the sort.

\footnotetext{
${ }^{1}$ We are not here directly concerned with Castle's contention that lloshino's results prove the effectiveness of selection within a pure line. I ean not, however, refrain from a few comments on that contention. Castle states $(1916 a$, p. 324), in connection with the differences in floweringtime between the offspring of early and late flowering sister-plants: "From long experience in studies of rats with such small differences as are here indicated I have no hesitation in concluding that fluctuating variation of genetic significance is here in evidence." One wonders how experience in dealing with differences in pigmentation in rats ean give an observer special ability in determining by inspection the signifieance of three-tenths of a day diffesence in the llowering time of peas. With respect to Castle's calculations from Hoshino's data, it may be pointed out that the greatest favorable difference recorded, 1.27 ditys, is incorrect, and should read 0.20 day. In view of the fact that there is no guarantee that the material used was homozyous, I have thought it scarcely worth while to recalculate all the differences, or to determine their probable errors; but it is certain that the probable error of each differenee is of the same order of magnitude as the average difference itself, $i$. e., about 0.3 day.
} 
Hayes has, by selection from a mixed population, established four different grades of variegation (including self-colored and colorless) that breed true and that represent four allelomorphs. The two intermediate types, "mosaic" and "pattern," are the ones of special interest in the present connection. When these two types were crossed, the mosaic type was dominant, but there was an increase in variability in $\mathrm{F}_{1}$ and some individuals with more pigment than either parent were obtained. The parent races had been selfed and selected for about six generations before the cross was made. In view of the great amount of heterozygosis that seems to be normally present in maize, and the large number of chromosome pairs (20?), this seems to be hardly sufficient to make certain that both races were pure for their modifiers. The increased variability of $F_{1}$ is therefore not surprising; and that phenomenon would of course be expected to be followed by a still greater increase in variability in $F_{2}$. Such an increase was, in fact, observed, and is the chief basis for Hayes's conclusion that contamination may occur. The data are not sufficient to demonstrate that new allelomorphs arise more often in heterozygotes than in homozygotes; and even if it be shown that they do so, it does not follow that there has been contamination of allelomorphs. There are too many unknown factors involved in the production of these new allelomorphs for such a conclusion to be valid without very careful controls.

It appears from the foregoing review that the cases cited as illustrations of contamination of allelomorphs or imperfect segregation are all explicable on the multiple-factor view, or rest on extremely indefinite data.

One series of data bearing on the question has been presented in this paper (p. 32), and has been interpreted as giving evidence against contamination. Three other cases have been worked out by Muller (1916) and Marshall and Muller (1917). Muller kept three mutant characters of Drosophila in heterozygous condition for about 75 generations. The factors were kept constantly in flies heterozygous for their normal allelomorphs, so that the characters remained unseen for a long time.

Muller extracted one of these characters (dachs) from this stock, and measured the tarsi, using the length of thorax as a standard of comparison. Dachs flies are characterized by shortened tarsi; and the flies from the heterozygous stock were found to have tarsi actually a trifle shorter than those found in a stock that had been kept pure for dachs. This result was not very conclusive, chiefly because it was based on a very few flies.

Marshall and Muller made much more extensive studies with the wing characters, curved and balloon, derived from the same heterozygous stock. They obtained a similar result; the wings were no nearer 
the normal than were those of curved and of balloon flies that had been kept in pure stocks. These results, taken in connection with the data presented above for bristle number in flies from lines heterozygous for Dichæt, furnish definite evidence against contamination of allelomorphs in heterozygous forms.

\section{Castle's Experiments witi Hooded Rats.}

Perhaps the best known selection experiment is that carried out by Castle and various collaborators (Castle and Phillips, 1914, Castle and Wright, 1916, etc.) with hooded rats. The theoretical conclusions reached by Castle are not in agreement with those arrived at by various other investigators, including the author, although for the most part the data obtained are very similar. Castle's results have been discussed by Muller (1914a) and MacDowell (1916), who have shown in detail that all the data known to them were explainable on the multiple-factor view, without recourse to such hypotheses as contamination of factors or production of factorial variations by selection. One point has, I think, not been sufficiently emphasized by them, namely, that the rat experiments are hard to evaluate properly until we are in possession of more accurate data regarding the pedigrees. Since these two criticisms were written, Castle (Castle and Wright, 1916) has given some additional data, which he has used, in a reply (Castle, 1917) to MacDowell's paper, as arguments against the latter's conclusions.

With regard to the question of pedigrees, to take up these questions in order, the main point on which information is desired is: How closely inbred were the rats, both before and after the beginning of the selection experiment? The following quotations contain most of the available evidence on this matter:

"Since the entire stock is descended from a very few individuals (less than a dozen), and we have at no time hesitated to mate together brother and sister, provided they varied in the same direction, but have alway's used the most extreme individuals (plus or minus) which were available, to mate with each other, it follows that very close inbreeding must have occurred throughout the experiment." (Castle, 1914b.)

"It is impossible for a colony of 33,000 rats to be produced from an original stock of less than a dozen animals, with constant breeding together of these which are alike in appearance and pedigree, and with continuous sclection of extremes in two opposite directions, without the production of pedigrees which in the course of each selection experiment interlock generation after generation and finally become in large part identical with each other. 'This has been repeatedly verified in individual cases, but is incapable of a more generalized statement or of demonstration in generalized form. At least I am unable to devise such demonstration." (Castle, 1916d.)

Elsewhere (Castle and Phillips, 1914, p. 20) it is stated that part of the original stock consisted in a mixed lot of trapped rats that "had probably arisen by the crossing of an escaped albino rat with wild 
ones." We do not know where the rest of the stock came from, and we do not know how the animals used to start the selection experiments were derived from these sources. We do not know how many individuals were used to start the selection experiment; and we do not know anything as to the relationship between the rats in the two series (plus and minus). And, finally, we have only very indefinite data as to what system of breeding was followed during the experiment. All this information is very much needed, if we are to know how to interpret the results. It is conceivable that each series was split up into a number of separate lines, and that these have been crossed from time to time. Such a system would result in bringing together modifying factors more slowly than would a system of very close inbreeding. It is, of course, very improbable that any such system has been followed; and such an assumption is by no means necessary for a multiple-factor interpretation of the results. But definite information is very desirable, as is indicated by an analogous case.

In connection with certain work that the writer has been carrying on with Mr. J. W. Gowen, pedigrees of the two famous thoroughbred race-horses, Sysonby and Artful, have been tabulated. These pedigrees are both practically complete for 10 ancestral generations. They constitute a fair random sample of pedigrees in the breed, for Sysonby was of pure English blood, while Artful had many Americanbred ancestors. The two pedigrees show no name in common until we reach the fifth ancestral generation. In that generation there are three names that appear in both pedigrees. But by the time we reach the tenth ancestral generation, approximately 90 per cent of the 1,024 names in Artful's pedigree appear also in the first ten generations of Sysonby's pedigree. And the result would certainly be even more striking if the pedigrees were studied for a few more generations, or if two English-bred horses were compared. Here, then, we have a clear case of "interlocking" pedigrees. Yet in spite of the long inbreeding (12 to 20 or more generations, with scarcely any out-crosses) which the breed has undergone, there are still a large number of bay or brown and of chestnut race-horses, besides a few grays and blacks. Of the four Mendelian factor pairs (see Sturtevant, 1912) for which the race was originally heterozygous, it has become homogeneous only in that the roan factor has been eliminated. ${ }^{1}$ Clearly, selection for any one of the colors now present would still be effective in eliminating the others. The breed, which we may suppose to be inbred to something like the same degree as Castle's hooded rats, is still very far from a "pure line."

The new data presented by Castle and not taken up by MacDowell consist of two points: The crosses of extracted hoodeds (from plus

\footnotetext{
${ }^{1}$ Even in the early day's roan race-horses were not at all common. Both roan and gray have been selected against.
} 
race $\times$ wild) to wild, and the relations of the "mutant" series to the selected series.

When the plus race was erossed to wild, and $\mathrm{F}_{2}$ hoodeds were extracted, it was found that in these extracted animals the mean grade was lighter (less "plus") than that of their selected grandparents. This, as MacDowell pointed out, is the expectation on the multiplefactor view. But Castle now states that when these extracted hoodeds are again crossed to wild, and hooded is extracted once more, the twice-extracted hoodeds are about midway in mean gradebetween their extracted grandparents and the uncrossed plus race. As he says, the wild race might have been expected to bring these animals still farther away from the plus race if modifying factors were involved. Evidently it is very important that we know as much as possible about the wild rats used in these experiments, in order that we may know what they were likely to carry in the way of modifying factors. These rats, we are told, all came from the same stock, which was trapped at the Bussey Institution in large numbers and was reared for two generations in the laboratory. "In making the second set of crosses, the extracted individual has, wherever possible, been crossed with its own wild grandparent." An examination of the table given shows that not more than 102 of the 256 twice-extracted hoodeds can have been produced in this way, unless individuals of the same sex were mated together. Just how many of the 102, and which ones, does "wherever possible" include? How many wild rats were used in the original crosses? These questions are important, because it is erident from a study of the data that the result emphasized by Castle is clue almost entirely to the descendants of one original plus-line female; 41 of the 73 once-extracted hoodeds were $\mathrm{F}_{2}$ 's from this female; and their mean grade was 3.05 , as against 3.3 for the remaining $\mathrm{F}_{2}$ 's, and 3.17 for the generation as a whole. The twice-extracted hoodeds tracing to this female were of mean grade 3.47 , while those from the other original hoodeds were again of approximately grade 3.3. Further data regarding the pedigree and other descendants of the mates of this female and of her grandchildren are very much needed. Information regarding the ancestry of the female herself would also be interesting.

It should also be pointed out that this ease, aceepted at its face value, is difficult to explain on the view that the hooded-rat results are produced solely by variations in the hooded factor itself. On that view the changes brought about by crossing are usually referred to contamination of the faetors in the heterozygote. But that interpretation leaves entirely unexplained the results of the first cross to wild. If the hooded factor is contaminated by its allelomorph, the onceextracted hoodeds should be darker than their grandparents, whereas in reality they are lighter, as would be expected on the multiple-factor 
view. Castle has met this objection in the following manner (Castle and Wright, 1916):

"This suggests the idea that that loss (of 'plus' character) may have been due to physiological causes non-genetic in character, such as produce increased size in racial crosses; for among guinea-pigs (as among certain plants) it has been found that $F_{1}$ has an increased size due to vigor produced by crossing and not due to heredity at all. This increased size persists partially in $\mathrm{F}_{2}$, but for the most part is not in evidence beyond $\mathrm{F}_{1}$. I would not suggest that the present case is parallel with this, but it seems quite possible that similar non-genetic agencies are concerned in the striking regression of the first $\mathrm{F}_{2}$ and the subsequent reversed regression in the second $\mathrm{F}_{2}$."

This comparison seems to me to be rather far-fetched, and I am quite unable to understand the hypothesis of "non-genetic physiological causes." That they are "physiological" is, of course, obvious; but they depend for their appearance on the pedigree of the animal, and they are persistent to $\mathrm{F}_{2}$, so why "non-genetic"? The results from size crosses are entirely explicable on the basis of Mendelian modifying factors, so why need one appeal to vague "non-genetic," yet transmissible, factors? And is not such an appeal, in principle, an appeal to modifying factors? It certainly involves the assumption that the grade depends on transmissible material other than the hooded factor itself.

In the tenth generation of Castle's plus selection series there appeared two rats of considerably higher grade than any individuals of that series previously recorded. These individuals were shown (Castle and Phillips, 1914, pp. 26-31) to differ from the plus race by a single dominant factor. This has been taken by MacDowell to indicate that a new modifying factor arose by mutation. But Castle has now presented evidence indicating that the mutation occurred in the hooded locus itself. When homozygous "mutants" were crossed to wild rats, $\mathrm{F}_{2}$ consisted in self-colored rats and rats of the same grade as the mutant series - no hooded individuals. (Castle and Wright, 1916.) Castle (1916) concludes from this evidence: "This serves to confirm the general conclusion that throughout the entire series of experiments with the hooded pattern of rats we are dealing with quantitative variations in one and the same genetic factor." Now, the "mutant" variation differs from the other results obtained by Castle in two respects: It appeared suddenly, as a definite and very slightly variable character, and it fails, when crossed to self, to give normal hooded in $\mathrm{F}_{2}$. Because of the first point, it is probable that it arose during the experiment as a new variation; because of the second, it is probable that it is a variation in the hooded factor itself. Since these conclusions as to its nature are based entirely on the points in which it differs from the remainder of the results, it is difficult to see how Castle's case for these results is in any way improved. On the contrary, if this is the behavior to be expected of a new variation 
arising in the hooded factor, then the "mutant" variation is evidently" the only case of that sort that Castle has reported.

\section{GENERAL CONCLUSIONS.}

That many characters may be influeneed by more than one pair of genes has long been recognized, and this is the essence of the multiplefactor view. That genes exist which require the action of other genes before they produce visible effects has also been long known. Furthermore, that there are genes which produce very slight visible effects is now another commonplace. Given these three facts, and the hypothesis (which is supported by much specific evidence) that most races are heterozygous for a number of such genes is all that is required to eomplete the conception that is held by most adherents of the view that multiple factors or modifying genes are responsible for the results of selection.

In specifie cases, the existence of definite modifying genes has been demonstrated by Dexter, Bridges, Muller and Altenburg, and the author. All other data in question fit in with the view that selection ordinarily acts only by isolating modifiers.

Modification of factors by selection, erossing, fractionation, or similar means is undemonstrated in any given case, and has been shown not to occur in other cases that are typieal of the results usually obtained. Factors do change, and more than two forms are possible for certain loci; but there is no known method of inducing such changes, and they are ordinarily quite rare and definite.

\section{SUMMARY.}

(1) Dichæt is a dominant character, the gene being lethal when homozygous (yellow-mouse case). The gene is in the third chromosome.

(2) Dichæt flies are more variable in bristle number than are notDichæts. This variability is partly environmental, partly genetic.

(3) Selection was effective in isolating both plus and minus Dichxt lines.

(4) A cross between two separate inbred plus lines gave no increase in variability and no increase in parent-offspring correlation. Therefore the two lines were presumably of very similar constitution, though independent in origin.

(5) A cross between an inbred plus line and an inbred minus line gave the results characteristic of such crosses-increased viriability in $\mathrm{F}_{2}$ and increased parent-offspring correlation.

(6) Linkage tests demonstrated that modifying genes exist in the selected lines. Several lines were shown to differ in one or more second-chromosome modifiers, and at least one of these modifiers was shown to eross over from the speck gene. 
(7) In one case at least one third-chromosome modifier was shown to exist and to cross over from Dichæt, which must lie to the left of it.

(8) Two third-chromosome lethals were obtained. These were shown to be new mutations, not due to fractionation of the Dichæt gene.

(9) A new allelomorph of Dichæt, called Extended, appeared in a plus selected line. It is argued that this mutation was not due to fractionation of the Dichæt gene, and was not influenced by the selection that was carried on.

(10) Another character, somatically indistinguishable from Extended, was shown to be due to a recessive second-chromosome gene.

(11) A study of unselected Dichæts, and of the not-Dichæts produced by long-continued mating together of Dichæts, is shown to furnish evidence against the view that allelomorphs are contaminated in heterozygotes.

(12) A general discussion of the selection problem is divided into three parts: (a) an attempt is made to clear up certain current misunderstandings and disagreements as to what questions are really at issue; (b) cases cited as evidence for contamination of allelomorphs are discussed in detail, and the conclusion is drawn that contamination is unproved and is an unnecessary hypothesis, with some direct evidence against it; $(c)$ certain specific objections are raised to arguments made by Castle on the basis of his experiments with hooded rats. 


\section{BIBLIOGRAPHY.}

BAtESON, W.

1909. Mendel's principles of heredity. 2d impression, Cambridge.

1914. Address of the president of the British Association. Science, n. 8., 40.

Bridges, C. B.

1915. A linkage variation in Drosophila. Jour. Exper. Zool., 19.

1916. Non-disjunction as proof of the chromosome theory of heredity. Geneties, 1.

Calkins, G. N., and L. H. Gregory.

1913. Variations in the progeny of a single ex-conjugant of Paramecium caudatum.

Castle, iW. E. Jour. Exper. Zool., 15.

1906. The origin of a polydactylous race of guinea-pigs. Carnegie Inst. Wash. Pub. 49.

1911. Heredity in relation to evolution and animal breeding. New York.

1914a. Multiple factors in heredity. Science, 39.

1914b. Variation and selection; a reply. Zeitschr. Abst. Vererb., 12.

1916a. New light on blending and Mendelian inheritance. Amer. Nat., 50.

1916b. Genetics and eugenics. Cambridge, Mass.

1916c. Report in Carnegie Inst. Wash. Year Book No. 15.

1916d. Can selection cause genetic change? Amer. Nat., 50.

1917. Piebald rats and multiple factors. Amer. Nat., 51.

and A. Forbes.

1906. Heredity of hair-length in guinea-pigs and its bearing on the theory of pure gametes. Carnegie Inst. Wash. Pub. 49.

and P. B. HADLEY.

1915a. The English rabbit and the question of Mendelian unit-character constancy. Amer. Nat., 49.

1915b. Same. Proc. Nat. Acad. Sci., 1.

and J. C. Phillips.

1914. Piebald rats and selection. Carnegie Inst. Wash. Pub. 195.

and S. Wright.

1916. Studies of inheritance in guinea-pigs and rats. Carnegie Inst. Wash. Pub. 241.

Dexter, J. S.

1914. The analysis of a case of continuous variation in Drosophila by a study of its

EMerson, R. A. linkage relations. Amer. Nat., 48.

1917. Genetical studies of variegated pericarp in maize. Genetics, 2.

HAYES, H. K.

1917. Inheritance of a mosaic pericarp pattern color of maize. Genetics, 2.

Hoshino, Y.

1915. On the inheritance of the flowering time in peas and rice. Journ. Coll. Agr.

Jexnings, H. S. Tohoku Imper. Univ., Sapporo, Japan, 6.

1916. Heredity, variation, and the results of selection in uniparental reproduction

JoHANNSEN, W. in Diflugia corona. Genetics, 1.

1903. Ueber Erblichkeit in Populationen und in reinen Linien. Jena.

Little, C. C.

1915. The inheritance of black-eyed white spotting in mice. Amer. Nat., 49.

LoTz, F. E.

1911. Experiments with Drosophila ampelophila concerning evolution. Carnegie Inst. Wash. Pub. 143.

MacCurdy, H., and W. E. Castle.

1907. Selection and cross-breeding in relation to the inheritance of coat-pigments and coat-patterns in rats and guinea-pigs. Carnegie Inst. Wash. I'ub. 70. 
MaCDowell, E. C.

1915. Bristle inheritance in Drosophila. I. Extra bristles. Jour. Exper. Zool., 19.

1916. Piebald rats and multiple factors. Amer. Nat., 50.

1917. Bristle inheritance in Drosophila. II. Selection. Jour. Exper. Zool., 23.

Marshall, W. W., and H. J. Muller.

1917. The effect of long-continued heterozygosis on a variable character in Drosophila. Jour. Exper. Zool., 22.

Middleton, A. R.

1915. Heritable variations and the results of selection in the fission rate of Stylonychia pustulata. Jour. Exper. Zool., 19.

Morgan, T. H., A. H. Sturtevant, H. J. Muller, and C. B. Bridges.

1915. The mechanism of Mendelian heredity. New York.

MULLER, H. J.

1914a. The bearing of the selection experiments of Castle and Phillips on the variability of genєs. Amer. Nat., 48.

1914b. A gene for the fourth chromosome of Drosophila. Jour. Exper. Zool., 17.

1916. The mechanism of crossing over. Amer. Nat., 50.

1917. An Oenothera-like case in Drosophila. Proc. Nat. Acad. Sci., 3.

Pearson, K.

1911. On the probability that two independent distributions of frequency are really

Spillman, W. J. samples from the same population. Biometrika, 8 .

1907. Inheritance of the belt in Hampshire swine. Science, n. s., 26.

Sturtevant, A. H.

1912. A critical examination of recent studies on color inheritance in horses. Journ. Genet., 2. 
DETAILED DATA.

Table 25.-Inbred Plus Series. 864 LiNe.

\begin{tabular}{|c|c|c|c|c|c|c|c|c|c|c|c|c|c|c|c|c|c|c|c|c|c|}
\hline \multirow{3}{*}{\multicolumn{2}{|c|}{$\begin{array}{l}\text { Genera- } \\
\text { tion and } \\
\text { culture } \\
\text { No. }\end{array}$}} & \multicolumn{3}{|c|}{ Parents. } & \multicolumn{2}{|c|}{1} & \multicolumn{2}{|c|}{2} & \multicolumn{2}{|l|}{3} & \multicolumn{2}{|l|}{4} & \multicolumn{2}{|l|}{5} & \multicolumn{2}{|l|}{6} & 7 & & 8 & & \\
\hline & & Gr: & de. & & & & & & & & & & & & & & & & & & \\
\hline & & 우 & $\sigma^{x}$ & ture. & ${ }^{*}$ & 0 & ${ }^{*}$ & 0 & 7 & $\sigma^{\prime}$ & 7 & $\sigma^{\prime}$ & 8 & $\sigma^{\prime}$ & 8 & б & 8 & $\sigma^{\prime \prime}$ & 8 & 8 & i \\
\hline & 893 & 6 & 7 & 864 & $\cdots$ & $\cdots$ & $\cdots$ & $\cdots$ & $\cdots$ & & ${ }^{1} 10$ & $\cdots$ & 127. & & ${ }^{1} 66$ & & ${ }^{1} 10$ & & & $\cdots$ & 113 \\
\hline$F_{2}$ & 902 & 7 & 6 & 893 & $\cdots$ & $\cdots$ & . & & & & 4 & 5 & 5 & 3 & 17 & 17. & & & & & 51 \\
\hline & 903 & 7 & 6 & 893 & . & $\ldots$ & $\ldots$ & $\cdots$ & $\cdots$ & 1 & 5 & 9 & $i$ & 17 & 17 & 14. & & & & & 70 \\
\hline $\mathrm{F}_{3}$ & 926 & 6 & 6 & 903 & . & $\cdots$ & .. & $\cdots$ & & & $\cdots$ & & 7 & 6 & 32 & $2 s$. & & & & & 73 \\
\hline$F_{4}$ & 1006 & 6 & 6 & 926 & $\ldots$ & $\cdots$ & . & 1 & 1 & 2 & 19 & 23 & 20 & 13 & 17 & 12. & & & & & 105 \\
\hline & 1013 & 6 & 6 & 926 & $\cdots$ & $\cdots$ & $\cdots$ & 1 & $\cdots$ & $\cdots$ & 25 & 24 & 26 & 27 & 28 & 21 & & & & & 152 \\
\hline$F_{5}$ & 1064 & 6 & 6 & 1006 & $\cdots$ & $\cdots$ & .. & $\cdots$ & $\cdots$ & 1 & 7 & 6 & 8 & $i$ & 10 & 9 & & & & . & 49 \\
\hline & 1081 & 6 & 6 & 13 & $\cdots$ & - & $\cdots$ & $\cdots$ & $\cdots$ & $\cdots$ & 1 & & 7 & 4 & 7 & 7 & & & - & ... & 26 \\
\hline & 1084 & 6 & 6 & 1013 & $\cdots$ & $\ldots$ & $\cdots$ & $\cdots$ & $\cdots$ & $\cdots$ & 9 & 5 & 21 & 9 & 11 & 20 & & & & & 75 \\
\hline$F_{6}$ & 1153 & 6 & 6 & 1064 & . & $\ldots$ & $\ldots$ & $\cdots$ & . & & & 1 & 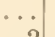 & $\begin{array}{l}1 \\
2\end{array}$ & 4 & 6 & & & & & 12 \\
\hline & $\begin{array}{l}1170 \\
1191\end{array}$ & 6 & 6 & $\begin{array}{l}10 \\
10\end{array}$ & $\cdots$ & $\ldots$ & $\ldots$ & $\cdots$ & $\cdots$ & $\ldots$ & 8 & $\begin{array}{l}1 \\
4\end{array}$ & 2 & $\begin{array}{r}3 \\
16\end{array}$ & $\begin{array}{r}7 \\
21\end{array}$ & 7 & 1 & & & $\cdots$ & 21 \\
\hline & 1 & 6 & 6 & 1001 & - & & $\cdots$ & $\cdots$ & & & 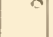 & 4 & 16 & 10 & 21 & 21 & & & & $\cdots$ & 87 \\
\hline $\mathrm{F}_{7}$ & 1239 & 6 & 6 & 1153 & $\cdots$ & $\cdots$ & $\cdots$ & $\cdots$ & $\cdots$ & $\cdots$ & & & 3 & 2 & 3 & 7 & & 2 & . & . . & 17 \\
\hline & 1277 & 6 & 6 & 1170 & $\cdots$ & $\cdots$ & $\cdots$ & $\cdots$ & $\cdots$ & $\cdots$ & 14 & 20 & 16 & 10 & 16 & 16 & & . & & & 02 \\
\hline & 1287 & 6 & 6 & 1191 & $\cdots$ & $\cdots$ & $\cdots$ & $\cdots$ & $\cdots$ & 1 & 6 & 4 & 9 & 13 & 16 & 18 & 1 & & & .. & 68 \\
\hline & 1298 & 6 & 6 & 1170 & $\ldots$ & $\cdots$ & $\cdots$ & $\cdots$ & $\ldots$ & $\ldots$ & 28 & 19 & 17 & 20 & 22 & 18 & . & & $\cdots$ & . & 124 \\
\hline & 1299 & 6 & 6 & 1170 & $\ldots$ & $\ldots$ & $\cdots$ & $\cdots$ & $\ldots$ & $\ldots$ & $\cdots$ & $\cdots$ & 4 & 3 & 14 & 12 & & & $\cdots$ & . & 33 \\
\hline & 1309 & 6 & 6 & 1170 & $\ldots$ & $\cdots$ & $\cdots$ & $\cdots$ & $\ldots$ & $\cdots$ & 10 & 6 & 4 & 14 & 16 & 19 & & 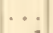 & $\ldots$ & . & 69 \\
\hline & 1318 & 6 & 6 & 1191 & $\ldots$ & $\ldots$ & $\ldots$ & $\cdots$ & $\ldots$ & 1 & 8 & 1 & 13 & 11 & 12 & 12 & 1 & 1 & $\ldots$ & $\ldots$ & 60 \\
\hline & 1322 & 6 & 6 & 1170 & $\ldots$ & $\ldots$ & $\cdots$ & $\cdots$ & $\ldots$ & $\cdots$ & 6 & 5 & 7 & 12 & 5 & 12 & & 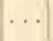 & $\ldots$ & $\ldots$ & 47 \\
\hline$F_{8}$ & 1384 & 6 & 7 & 1239 & $\ldots$ & $\ldots$ & $\ldots$ & $\ldots$ & $\ldots$ & $\ldots$ & 1 . & 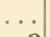 & 3 & 3 & 7 & 8 & & . & $\ldots$ & $\ldots$ & 22 \\
\hline & 1390 & 6 & 6 & 1277 & . & $\cdots$ & $\cdots$ & $\cdots$ & $\cdots$ & $\cdots$ & 3 & 3 & 1 & 9 & 2 & 7 & & & . & $\cdots$ & 25 \\
\hline & 1405 & 6 & 6 & 1277 & $\ldots$ & $\cdots$ & $\ldots$ & $\cdots$ & $\cdots$ & $\cdots$ & 4 & 1 & 4 & 4 & 6 & 5 & & & . & . & 24 \\
\hline & 1420 & 6 & 6 & 1298 & $\ldots$ & $\cdots$ & $\ldots$ & $\cdots$ & $\cdots$ & $\cdots$ & 1 & 2 & 4 & 5 & 5 & 4 & 1 & & $\ldots$ & . & 22 \\
\hline & 1421 & 6 & 6 & 1298 & $\ldots$ & $\ldots$ & $\ldots$ & $\ldots$ & $\cdots$ & 1 & 13 & 16 & 16 & 14 & 21 & 14 & 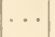 & & $\ldots$ & . & 95 \\
\hline & 1422 & 6 & 6 & 1299 & $\ldots$ & . & . . & $\ldots$ & $\ldots$ & $\ldots$ & 1. & 1 & 11 & 6 & $3 s$ & 35 & & & $\ldots$ & *. & 92 \\
\hline & 1430 & 7 & 6 & 1287 & 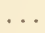 & $\ldots$ & $\ldots$ & $\ldots$ & $\ldots$ & $\ldots$ & 3. & 2 & 10 & 6 & 17 & 22 & & & . & $\cdots$ & 60 \\
\hline & 1431 & 6 & 6 & 1309 & 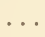 & $\ldots$ & $\ldots$ & $\ldots$ & $\ldots$ & ... & 2 & $\ldots$ & 6 & 5 & 3 & 4 & & 1 & . & . & 21 \\
\hline & 1444 & 6 & 6 & 1287 & & $\ldots$ & $\ldots$ & $\ldots$ & $\ldots$ & & $\ldots$ & $\ldots$ & $\ldots$ & 3 & 12 & 9 & 2 & 1 & . & . & 27 \\
\hline & 1459 & 6 & 6 & 1287 & & $\ldots$ & . & $\ldots$ & $\ldots$ & & & $\ldots$ & & & 6 & 7 &. & $\cdots$ & 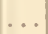 & & 13 \\
\hline & 1478 & 6 & 6 & 1298 & $\cdots$ & $\ldots$ & $\ldots$ & $\ldots$ & $\cdots$ & $\cdots$ & 5 & 1 & 7 & 10 & 19 & 17 & 1 & & . . & & 60 \\
\hline$F_{9}$ & 1511 & 6 & 6 & 1390 & . . & . & ... & $\cdots$ & $\cdots$ & & 2 & . & 1 & 3. & 5 & 4 & & $\cdots$ & . & . & 15 \\
\hline & 1576 & 6 & 6 & 1421 & . & $\ldots$ & $\ldots$ & $\ldots$ & $\ldots$ & 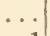 & 3 & 2 & 8 & 6 & 19 & 16 & 1 & & $\ldots$ & • & 55 \\
\hline & 1613 & 6 & 6 & 1459 & & . & & $\ldots$ & $\ldots$ & 1 & 1 & $\ldots$ & 1 & 7 & 19 & 24 & $\ldots$ & & . & & 53 \\
\hline & 1629 & 7 & 6 & 1444 & & & & $\cdots$ & $\ldots$ & $\ldots$ & $\ldots$ & $\ldots$ & 3 & 1 & 3 & 3 & & & . & & 10 \\
\hline & 1690 & 7 & 6 & 1478 & . & 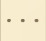 & & & & & & $\cdots$ & 2 & 5 & 7 & 7 & & 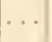 & & & 21 \\
\hline$F_{10}$ & 1663 & 6 & 6 & 1511 & & 1. & . & $\ldots$ & . & & a & 1 & 1 & 6 & 3 & 1 & & & & . & 11 \\
\hline & 1763 & 6 & 6 & 1613 & ... & $\ldots$ & $\ldots$ & 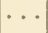 & $\cdots$ & 1 & 4 & 4 & 2 & 7 & 4 & 14 & 1 & & & & 37 \\
\hline & 1810 & 6 & 6 & 1613 & & $\cdots$ & 1 & $\cdots$ & $\cdots$ & 8 & 20 & 14 & 15 & 17 & 18 & 15 & $\cdot$ & 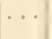 & & & 111 \\
\hline$F_{11}$ & 1887 & 6 & 6 & 1763 & $\cdots$ &. & .. & $\because$ & $\ldots$ & $\cdots$ & 2 & 4 & 6 & 10 & 24 & 11 & & . & & . & 57 \\
\hline & 1890 & 7 & 6 & 1763 & $\ldots$ & $\ldots$ & $\cdots$ & 1 & $\ldots$ & 3 & 4 & 5 & 9 & 6 & 14 & 16 & & . & $\cdots$ & . & 58 \\
\hline & 1944 & 6 & 6 & 1810 & . & $\ldots$ & $\ldots$ & $\cdots$ & $\ldots$ & 2 & 7 & 7 & 14 & 14 & 16 & 5 & $\cdot$ & . & . & $\ldots$ & 65 \\
\hline & 1963 & 6 & 6 & 1810 & & $\ldots$ & $\ldots$ & $\cdots$ & $\ldots$ & 2 & 4 & 3 & 5 & 6 & 4 & 5 & & & & . & 29 \\
\hline & 1982 & 6 & 6 & 1810 & & 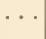 & - & $\cdots$ & $\cdots$ & $\cdots$ & $\cdots$ & 3 & 2 & 6 & 6 & 5 & 1 & & & $\cdots$ & 23 \\
\hline$F_{12}$ & 2013 & 6 & 6 & 1887 & & . & & 2 & $\cdots$ & 5 & 14 & 16 & 11 & 12 & 20 & 11 & 1 & 3 & & & 95 \\
\hline & 2027 & 6 & 6 & 1887 & & . & $\cdots$ & $\cdots$ & $\cdots$ & & $\cdots$ & $\ldots$ & $\ldots$ & 3 & 17 & 25 & 1 & 1 & & & 47 \\
\hline & 2028 & 6 & 6 & 1890 & & $\ldots$ & $\ldots$ & $\ldots$ & $\ldots$ & & $\cdots$ & & 1 & 2 & 18 & 12 &. & 1 & & & 34 \\
\hline & 2029 & 6 & 6 & 1890 & & . & $\cdots$ & $\cdots$ & . & 3 & 7 & $\delta$ & 7 & 16 & 17 & 15 & 1 & 1 & & & is \\
\hline & 2060 & 6 & 6 & 1887 & & . & $\ldots$ & 1 & $\ldots$ & 4 & 9 & 6 & 8 & 9 & 12 & 20 & 1 & & & & \% \\
\hline & 2061 & 6 & 6 & $1 S 90$ & & 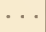 & 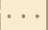 & $\cdots$ & . & 1 & 4 & 4 & 10 & 16 & 17 & 12 & 1 & & & & 65 \\
\hline & 2062 & 6 & 6 & 1890 & & & & $\ldots$ & .. & $\ldots$ & & $\ldots$ & $\cdots$ & 1 & 3 & 3 & & & & & -7 \\
\hline & 2087 & 6 & 6 & 1857 & & & $\cdots$ & $\ldots$ & 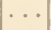 & & 4 & 1 & 1.3 & 11 & 11 & 9 & 1 & & & & 50 \\
\hline & 2098 & 6 & 6 & $19+4$ & & . & $\cdots$ & $\cdots$ & . & 4 & 6 & 2 & 5 & 5 & 1 & 6 & 1 & & & & 30 \\
\hline & 2105 & 6 & 6 & 1887 & & . & & 1 & . & 4 & 13 & 10 & 9 & 11 & 15 & 7 & & 1 & & & il \\
\hline & 2115 & 6 & 6 & $19 \cdot 14$ & & . & . & $\ldots$ & $\ldots$ & ... & 1 & 1 & 5 & 3 & 11 & 4 & & & & & 25 \\
\hline & 2123 & 6 & 6 & 1963 & & - & $\cdots$ & . & 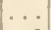 & 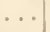 & 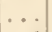 & $\cdots$ & 3 & 5 & 3 & 4 & & $\cdots$ & & & 15 \\
\hline & $2142^{2}$ & 6 & 6 & 1887 & & & & 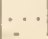 & 1 & & 1 & 1 & 2 & 3 & 19 & 17 & & & & & 44 \\
\hline
\end{tabular}


Table 25.-Inbred Plus Series. 864 Line-Continued.

\begin{tabular}{|c|c|c|c|c|c|c|c|c|c|c|c|c|c|c|c|c|c|c|c|c|}
\hline \multirow{3}{*}{$\begin{array}{c}\text { Genera- } \\
\text { tion and } \\
\text { culture } \\
\text { No. }\end{array}$} & \multicolumn{3}{|c|}{ Parents. } & \multicolumn{2}{|c|}{1} & \multicolumn{2}{|c|}{2} & \multicolumn{2}{|c|}{3} & \multicolumn{2}{|c|}{4} & \multicolumn{2}{|c|}{5} & \multicolumn{2}{|c|}{6} & \multicolumn{2}{|c|}{7} & \multicolumn{2}{|c|}{8} & \multirow{3}{*}{ 至 } \\
\hline & \multicolumn{2}{|c|}{ Grade. } & \multirow{2}{*}{$\begin{array}{l}\text { Cul- } \\
\text { ture. }\end{array}$} & \multirow{2}{*}{ q } & \multirow{2}{*}{$\sigma^{7}$} & \multirow{2}{*}{ q } & \multirow{2}{*}{$\sigma^{7}$} & \multirow{2}{*}{ q } & \multirow{2}{*}{$\sigma^{7}$} & \multirow{2}{*}{ 우 } & \multirow{2}{*}{$\sigma^{\pi}$} & \multirow[b]{2}{*}{ \% } & \multirow{2}{*}{$\sigma^{x}$} & \multirow{2}{*}{ q } & \multirow{2}{*}{$\sigma^{x}$} & \multirow[b]{2}{*}{ q } & \multirow[b]{2}{*}{$\sigma^{7}$} & \multirow[b]{2}{*}{ q } & \multirow[b]{2}{*}{$0^{7}$} & \\
\hline & \% & $\sigma^{7}$ & & & & & & & & & & & & & & & & & & \\
\hline $\mathrm{F}_{13} 2132$ & 7 & 7 & 2013 & 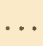 & 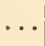 & & & . & & & 1 & 2 & & 6 & 6 & & & & $\cdots$ & 15 \\
\hline & 7 & 7 & & & & & & & & 2 & & 7 & 8 & 19 & 25 & 3 & & & & 64 \\
\hline 2146 & 0 & 7 & 20 & & & & $\cdots$ & . & 2 & & 1 . & 6 & 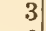 & 23 & 17 & .. & 1 & & & 53 \\
\hline 2 & 7 & 6 & 206 & . & & & & & $\cdots$ & 2 & 1 & 8 & 6 & 20 & 31 & 4 &. & & & 82 \\
\hline 2 & 6 & 6 & 20 & 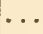 & & 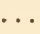 & .. & & .. & 1 & & 3 & 2 & 21 & 13 & 2 & 2 & & & 44 \\
\hline 2 & 7 & 6 & $20 s$ & . & & & & . & 1 & 3 & 3 & 6 & 8 & 16 & 10 & 1 & 2 & & .. & 50 \\
\hline 222 & 6 & 7 & 210 & .. & & - & . & $\cdots$ & $\cdots$ & 1 & & .. & 1 & 12 & 2 & 2 & .. & & ... & 18 \\
\hline 2241 & 6 & 7 & 202 & & & & & • & & $\cdots$ & & 1 & - & 14 & 14 & 5 & 3 & & & \\
\hline $\mathrm{F}_{14} 2248$ & 6 & 6 & 213 & & & & . & & & . & 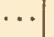 & 1 & 3 & 27 & 25 & 4 & 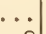 & & .. & 60 \\
\hline 229 & I & 6 & 216 & & & & & & & & & & 1 & 14 & 9 & 6 & 8 & & & 38 \\
\hline 2 & 6 & 7 & 218 & & & & . & ... & & . & ... & ${ }^{1} 1$ &. & ${ }^{125}$ & .. & ${ }^{1} 1$ & .. & ${ }^{1} 1$ & & 28 \\
\hline . & 6 & 7 & 221 & & & & & $\bullet$ & & 1 . & ... & 2 & 4 & 9 & 12 & 2 & 1 & & & 31 \\
\hline 2362 & 7 & 7 & 2241 & & & & & & & & 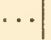 & & ( & 8 & 6 & 2 & 2 & & & 18 \\
\hline
\end{tabular}

${ }^{1}$ The original record sheet for 2301 has been lost, and the sexes are not noted separately on the copy from which this count is taken.

Table 26.-Inbred Plus Series. 1002 Line.

\begin{tabular}{|c|c|c|c|c|c|c|c|c|c|c|c|c|c|c|c|c|c|c|c|c|}
\hline \multirow{3}{*}{$\begin{array}{c}\text { Genera- } \\
\text { tion and } \\
\text { culture } \\
\text { No. }\end{array}$} & \multicolumn{3}{|c|}{ Parents. } & \multicolumn{2}{|c|}{1} & \multicolumn{2}{|c|}{2} & \multicolumn{2}{|c|}{3} & \multicolumn{2}{|c|}{4} & \multicolumn{2}{|c|}{5} & \multicolumn{2}{|l|}{6} & \multicolumn{2}{|c|}{7} & \multicolumn{2}{|c|}{8} & \multirow{3}{*}{ हू } \\
\hline & \multicolumn{2}{|c|}{ Grade. } & \multirow{2}{*}{$\begin{array}{l}\text { Cul- } \\
\text { ture. }\end{array}$} & \multirow{2}{*}{ } & \multirow{2}{*}{$\sigma^{x}$} & \multirow{2}{*}{ क } & \multirow{2}{*}{$0^{7}$} & \multirow{2}{*}{ \% } & \multirow{2}{*}{$\sigma^{x}$} & \multirow[b]{2}{*}{ 웅 } & \multirow[b]{2}{*}{$\sigma^{7}$} & & & & & & & & & \\
\hline & q & $0^{7}$ & & & & & & & & & & ? & $\sigma^{7}$ & q & $\sigma^{7}$ & q & $\sigma^{7}$ & 7 & $\sigma^{\prime}$ & \\
\hline$F_{1} 1072$ & 6 & 6 & 1002 & $\cdots$ & . & - & . & . & .. & 20 & 14 & 17 & 21 & 16 & 26 & & & & & 114 \\
\hline $\mathrm{F}_{2} 1150$ & 6 & 6 & 1072 & & & & & & & 5 & 11 & 15 & 17 & 42 & 30 & 1 & & & & 121 \\
\hline $\begin{array}{ll}N_{2} & 1158\end{array}$ & 6 & 6 & 1072 & . & .. & & & & $i$ & 35 & 30 & 11 & 12 & 11 & 10 . & & & . & & 110 \\
\hline $\mathrm{F}_{3} 1213$ & 7 & 6 & 1150 & & & & & & & 4 & 1 & 14 & 20 & 32 & 46 & 1 & & 1 & & 120 \\
\hline $\begin{array}{l}3 \\
-3233\end{array}$ & 6 & 6 & 1150 & & & & & & & & & $\begin{array}{r}2 \\
2\end{array}$ & 1 & 16 & 11 . & & $\dot{2}$ & & & 32 \\
\hline 1247 & 6 & 6 & 1158 & 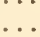 & $\cdots$ & & & $\cdots$ & & 5 & 5 & 6 & 11 & 24 & 29 . & & & & & 80 \\
\hline 1264 & 6 & 6 & 1150 & & -1 & & & & & 2 & 1 & 3. & 5 & 37 & 33 & 2 & 1 & $\ldots$ & & 84 \\
\hline 1278 & 6 & 6 & 1150 & . & $\ldots$ & & & & & 22 & 28 & 24 & 20 & 14 & 22 &. & & $\cdots$ & & 130 \\
\hline $\mathrm{F}_{4} 1347$ & 6 & 8 & 1213 & & & & & & & 11 & 11 & 17 & 16 & 39 & 27 & 1 & & . & & 122 \\
\hline 1348 & 6 & 6 & 1213 & . & . & & & & i) & 16 & 11 & 16 & 6 & 12 & 9 . & 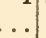 & $\dot{2}$ & & & 73 \\
\hline 1350 & 6 & 6 & 1247 & & & & & 1 & 3 & 54 & 33 & 34 & 13 & 12 & 12 & i) & & & & 163 \\
\hline 1363 & 6 & 6 & 1213 &. & . & & & & 1 & 4 & 1 & 4 & 5 & 7 & 4 & 1 & & & & 27 \\
\hline 1374 & 6 & 6 & 1247 & & & & & 1 & 1 & 14 & 14 & 6 & 6 & 17 & 13. & & & & & 72 \\
\hline 13 & 6 & 6 & 1247 & . & . & & 3 & . & 2 & 22 & 17 & 11 & 12 & 23 & 16 & & & & & 106 \\
\hline 13 & 6 & 6 & 1213 & & & & & 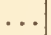 &. & 3 & & 3 & 9 & 16 & 13. & & & ... & . & 44 \\
\hline 13 & 7 & 6 & 1264 & .. & & .. & . & $\ldots$ &. & 9 & 9 & 10 & 5 & 2 & 9 . & & & & & 44 \\
\hline 13 & 7 & 6 & 1264 & & & 1 & & 1 & 4 & 7 & 7 & 5 & 5 & 3 & 3 . & & & & & 36 \\
\hline 13 & 6 & 6 & 1247 & . & 1 & & & & 5 & 21 & 15 & 5 & 18 & 6 & 8. & & & & . & 79 \\
\hline 1389 & 6 & 6 & 1247 & $\cdots$ & $\cdots$ & & & & . & 2 & & 1 & 1 & 5 & 5 . & & & & & 14 \\
\hline 1401 & 8 & 6 & 121 & . & & & & & & 15 & 8 & 6 & 17 & 19 & 21. & & & & .. & 86 \\
\hline 14 & 7 & 6 & 121 & & & & & & & 6 & 4 & 8 & 4 & 14 & 9 & 1 . & & & & 46 \\
\hline & 6 & 7 & 12 & & & & & & & 1 & 1 & 1 & 6 & 22 & 25. & & & & & 56 \\
\hline 14 & 6 & 7 & 1264 & & & & i) & & & 1 . & & 1 & 5 & 24 & 22 & & & & & 54 \\
\hline & 6 & 6 & 126 & & & & & & . & 9 & 6 & 20 & 12 & 42 & 35 . & & 1 & & & 125 \\
\hline 1436 & 6 & 6 & 1264 & & & & & & i). & & 2 & 6 & 5 & 22 & 16. & & 2 & &. & 52 \\
\hline$F_{5} 1479$ & 7 & 6 & 1350 & & & & & & 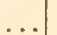 & 9 & 6 & 17 & 7 & 14 & 24. & & & & & 77 \\
\hline$N_{5} 1494$ & 6 & 6 & 13 & & & & & & & 2 & & 6 & 5 & 21 & 27 & 2 . & & & & 63 \\
\hline & 6 & 6 & 135 & & & & & & .. & 5 & 4 & 5 & 14 & 18 & 30 . & & & & & 76 \\
\hline 15 & 6 & 6 & 1347 & & & & & & .. & 11 & 4 & 18 & 9 & 36 & 45 & 4 i. & & & & 127 \\
\hline & 6 & 6 & 1363 & & & & & & $\ldots$ & 2 & 1 & 6 & 3 & 39 & 36 & 4 & 2 & & & 93 \\
\hline 15 & 6 & 6 & 1389 & . &. & &. & & $\ldots$ & 17 & 13 & 17 . & 15 & 13 & 23 . & & .1. & & & 98 \\
\hline 1516 & 6 & 6 & 1404 & & & & & & & 1 & 1 & 8 & 3 & 50 & 44 & 6 & 3 . & & & 116 \\
\hline
\end{tabular}


Table 26.-Inbred Plus Series. 1002 Ijine-Continued.

\begin{tabular}{|c|c|c|c|c|c|c|c|c|c|c|c|c|c|c|c|c|c|c|c|c|}
\hline \multirow{3}{*}{$\begin{array}{l}\text { Genera- } \\
\text { tion and } \\
\text { culture. } \\
\text { No. }\end{array}$} & \multicolumn{3}{|c|}{ Parents. } & \multicolumn{2}{|c|}{1} & \multicolumn{2}{|c|}{2} & \multicolumn{2}{|c|}{3} & \multicolumn{2}{|c|}{4} & \multicolumn{2}{|c|}{5} & \multicolumn{2}{|l|}{6} & \multicolumn{2}{|c|}{7} & \multicolumn{2}{|c|}{8} & \\
\hline & & ade. & & & & & & & & & & & & & & & & & & \\
\hline & 9 & $0^{x}$ & & 9 & $\sigma^{7}$ & 9 & $\sigma^{7}$ & ? & $0^{x}$ & q & $\sigma^{x}$ & \% & $0^{\pi}$ & 9 & $\sigma^{7}$ & P & $\sigma^{7}$ & 8 & $0^{7}$ & $\stackrel{0}{-1}$ \\
\hline$F_{5} 1529$ & 6 & 6 & 1387 & & & & & & 1 & 1 & 7 & 6 & 13 & 30 & & 1 & 1 & & & \\
\hline 1539 & 6 & 6 & 1403 & & & & & & & i) & 1 & 12 & 2 & 32 & 36 & 4 & & & & 88 \\
\hline 1540 & 7 & 6 & 1402 & • & & & & & & & & & 3 & 15 & 12 & 1 & & & & 31 \\
\hline 1543 & 6 & 6 & 1401 & ... & & & & & & 3 & 2 & 11 & 5 & 25 & 23 & 3 & & & & 72 \\
\hline 1546 & 6 & 7 & 1348 & . & & & & & & & & & & 7 & 5 & 3 & & 1 & 1 & 17 \\
\hline 1549 & 6 & 6 & 1375 & $\cdots$ & & & $\cdots$ & & & 16 & & 7 & 10 & 19 & 26 & 1 & & & & 70 \\
\hline 1556 & 6 & 6 & 1403 & $\ldots$ & & & $\ldots$ & . & 0 & 2 & 2 & 7 & 3 & 33 & 26 & 3 & 4 & & & 80 \\
\hline & 6 & 6 & 1383 & $\cdots$ & & & $\cdots$ & & & 1 & & 2 & & 21 & 10 & 4 & & & & 38 \\
\hline $\mathrm{F}_{6} 1611$ & 7 & 6 & 1502 & .. & & $\cdots$ & • & & & 3 & 2 & 3 & 7 & 12 & 3 & 2 & & & & 32 \\
\hline 1637 & 7 & 6 & 1509 & & & & & & & 1 & & 6 & 1 & 15 & 14 . & & & & & 37 \\
\hline 1644 & 6 & 6 & 1494 & ... & & $\cdots$ & $\cdots$ & & & 10 & 11 & 17 & 20 & 14 & 11 . & & & & & 89 \\
\hline 1671 & 7 & 6 & 1494 & $\ldots$ & & 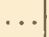 & $\ldots$ & & & 1 & $\ldots$ & 1 & $\ldots$ & 9 & 17. & & & & & 28 \\
\hline 1679 & 7 & 6 & 1539 & ... & & ... & $\ldots$ & & & & 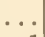 & .. & . & 8 & 4 & 2 & & & & 14 \\
\hline 1680 & 7 & 6 & 1546 & ... & & & $\ldots$ & 1 & 1 & 2 & 1. & 2 & 4 & 17 & 22 . & . & & & & 50 \\
\hline 1681 & 7 & 6 & 1546 & ... & & .. & $\ldots$ & $\ldots$ & 1 & 3 & 4 & 10 & 16 & 29 & 22 & 1 & 1 & & & 87 \\
\hline 1692 & 7 & 7 & 1556 & & & & $\ldots$ & & .. & & & & 1 & 12 & 9 & 3 & 3 & 1 & & 29 \\
\hline 1694 & 7 & 6 & 1558 & & & & $\%$ & & 1 & 11 & 3 & 10 & 16 & 20 & 20. & .. & & & & 81 \\
\hline 1712 & 7 & 6 & 1558 & $\ldots$ & & 1 & $\ldots$ & 2 & 4 & 10 & 5 & 13 & 12 & 17 & 15. & .. & & & & 79 \\
\hline 1731 & 7 & 7 & 1516 & $\ldots$ & & & $\ldots$ & & & & & & & 17 & 13 & 1 & & & & 31 \\
\hline 1734 & 6 & 6 & 1498 & $\cdots$ & & .. & $\ldots$ & . & 3 & 11 & 10 & 20 & 11 & 9 & 11 . & 1 & & & & 75 \\
\hline $\mathrm{F}_{7} 1788$ & 7 & 6 & 1611 & $\ldots$ & & & . & & . & 2 & 3 & 9 & 7 & 25 & 20 & 1 & 1 & & & 68 \\
\hline 1803 & 7 & 6 & 1679 & & & & & & & .. & & & & 8 & 10. & & & & & 18 \\
\hline 1811 & 7 & 7 & 1692 & . & & . & .. & & $\ldots$ & $\cdots$ & .. & 1 & 2 & 13 & 14 & 4 & & & & 34 \\
\hline 1830 & 6 & 7 & 1692 & & & & $\cdots$ & & $\cdots$ & $\cdots$ & 1 & & 1 & 14 & 14 & 3 & & & & 33 \\
\hline 1831 & 8 & 7 & 1692 & ... & & & $\ldots$ & & 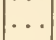 & 13 & 5 & 11 & 16 & 25 & 19. & 1 & $\cdots$ & & & 89 \\
\hline 1870 & 6 & 6 & 1731 & $\ldots$ & & & $\cdots$ & & & 1 & .. & 3 & 2 & 16 & 18. & 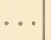 & 1 & & & 41 \\
\hline $\mathrm{F}_{8} 1912^{1}$ & 6 & 7 & 1788 & . & & & & 1 & 3 & 5 & 3 & 6 & 11 & 19 & 22 . & . & & & & 70 \\
\hline $1998^{1}$ & 6 & 7 & 12 & & & & & & 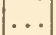 & 1 & & 2 & 3 & & 6. & & & & & 12 \\
\hline 1913 & 6 & 6 & 1788 & . & & & $\cdots$ & & $i$ & 8 & 3 & 10 & 2 & 10 & 8. & & & & & 42 \\
\hline $1924^{1}$ & 7 & 6 & 17 & . & & & $\cdots$ & & & 1 & 1 & 2 & 4 & 7 & 10. & & & & & 25 \\
\hline $1999^{1}$ & 7 & 6 & 1788 & . & & $\ldots$ & i) & ... & 5 & 4 & 1 & 6 & 5 & 10 & 7. & & & & & 39 \\
\hline 1939 & 6 & 6 & 1788 & & & & ... & & ... & 1 & 1 & 1 & 3 & 7 & 7 & 1 & & & & 21 \\
\hline 1945 & 7 & 6 & 1811 & & & & & & $\ldots$ & & & 1 & & 9 & 15 . & & & & & 25 \\
\hline 1949 & 6 & 6 & 1831 & . & & $\cdots$ & & $\cdots$ & 2 & 34 & 17 & 21 & 16 & 15 & 10. & & 1 & & & 116 \\
\hline 1974 & 7 & 6 & 1811 & . & & . . & & ... & 1 & 4 & 6 & 9 & 6 & 19 & 17 . & & & & & 62 \\
\hline 1976 & 7 & 6 & 1830 & - & & • & & $\cdots$ & 1 & 5 & 3 & 4 & 4 & 7 & 11. & & .. & & & 35 \\
\hline 1977 & 7 & 6 & 1830 & . & & $\cdots$ & & $\cdots$ & 5 & 17 & 12 & 18 & 20 & 15 & 19 . & .. & 1 & & & 110 \\
\hline 2000 & 6 & 6 & 1870 & . & & & & & $\ldots$ & $\ldots$ & $\cdots$ & 1 & & 13 & 12 & 1 & & & & 27 \\
\hline $\mathrm{F}_{2} 2036$ & 7 & 6 & 1939 & & & & & & 2 & 3 & 7 & 6 & 5 & 14 & 7 & 1 & & & & 45 \\
\hline 2096 & 6 & 7 & 1 & & & & & & & & & 7 & 4 & 27 & 14 . & & & & & 52 \\
\hline 2101 & 6 & 6 & 1912 & & & & & . & $\cdots$ & 2 & 5 & 7 & 8 & 17 & 14 . & & & & & 53 \\
\hline 2116 & 6 & 6 & 1945 & & & & & & & 1 & 1 & 8 & 6 & 15 & 6 . & & & & & 37 \\
\hline 2117 & 6 & 6 & 1974 & & & & & & & 8 & 5 & 4 & 6 & 13 & 15. & & 1 . & & & 52 \\
\hline 2129 & 6 & 6 & 200 & & & & & & & & .. & & & 5 & 4 & & & & & $\theta$ \\
\hline 21 & 6 & 6 & 1977 & & & & & & 1 & 9 & 7 & 12 & 9 & 8 & 5 & & & & & 51 \\
\hline 21 & 6 & 6 & 2000 & & & & & & & .. & $\cdots$ & 2 & & 17 & 14 & & & & & 33 \\
\hline 2147 & 7 & 6 & 2000 & 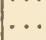 & & & & & & & & . & .. & 24 & 23 & 2 & 1 & & & 50 \\
\hline $\mathrm{F}_{10} 2199$ & 6 & 6 & 2096 & & & & & & & 2 & 1 & 6 & 12 & 32 & 32 & 1 & 1 & & & 87 \\
\hline 2231 & 6 & 6 & 212 & & & & & & & & & & & 10 & 13 & 1 & 5 & & & 29 \\
\hline 2232 & 6 & 7 & 2117 & & & & & & & & & 4 & 1 & 26 & 31 & 1 & 1 & & & 64 \\
\hline 2247 & 6 & 6 & 2134 & - & & & . & & & & & 1 & . & 26 & 27 & 2 & & & & 50 \\
\hline 2308 & 6 & 7 & 2147 & & 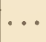 & & & & & & & .. & .. & 13 & 16 & 2 & 1 & 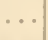 & 1 & 33 \\
\hline$F_{11} 2338$ & 6 & 7 & 2199 & & & & & & & & & 1 & 2 & 34 & 28 & 8 & 2 & n & & 77 \\
\hline 2354 & 7 & 7 & 2232 & & & & & & & & & $\ldots$ & .. & 11 & 20 & 4 & 1 & & & 30 \\
\hline 2389 & 7 & 6 & 2247 & & & & & & & & & & & 8 & 7 & 2 & 3 & & & 20 \\
\hline
\end{tabular}

${ }^{1} 1912$ and 1998,1924 and 1999 , represent two broods from the same parents. 
Table 27.-Inbred Plus Series. 1002 Line. New Set.

\begin{tabular}{|c|c|c|c|c|c|c|c|c|c|c|c|c|c|c|c|c|c|c|c|c|}
\hline \multirow{3}{*}{$\begin{array}{c}\text { Genera- } \\
\text { tion and } \\
\text { culture } \\
\text { No. }\end{array}$} & \multicolumn{3}{|c|}{ Parents. } & \multicolumn{2}{|c|}{1} & \multicolumn{2}{|c|}{2} & \multicolumn{2}{|c|}{3} & \multicolumn{2}{|c|}{4} & \multicolumn{2}{|c|}{5} & \multicolumn{2}{|l|}{6} & \multicolumn{2}{|c|}{7} & \multicolumn{2}{|c|}{8} & \multirow{3}{*}{ 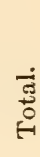 } \\
\hline & \multicolumn{2}{|c|}{ Grade. } & \multirow{2}{*}{$\begin{array}{l}\text { Cul- } \\
\text { ture. }\end{array}$} & \multirow[b]{2}{*}{ ㅇ } & \multirow[b]{2}{*}{$0^{7}$} & \multirow[b]{2}{*}{ ? } & \multirow[b]{2}{*}{$\sigma^{2}$} & \multirow[b]{2}{*}{ के } & \multirow[b]{2}{*}{$\sigma^{2}$} & \multirow[b]{2}{*}{ 안 } & \multirow[b]{2}{*}{$0^{x}$} & \multirow[b]{2}{*}{ q } & \multirow[b]{2}{*}{$\sigma^{7}$} & \multirow[b]{2}{*}{ 9 } & \multirow[b]{2}{*}{$0^{7}$} & \multirow[b]{2}{*}{ q } & & & & \\
\hline & 우 & $\sigma^{7}$ & & & & & & & & & & & & & & & $0^{7}$ & 웅 & $\sigma^{7}$ & \\
\hline 2415 & $\mathrm{M}$ & & $\begin{array}{l}\text { About } F_{2} \\
\text { from } 2389\end{array}$ & & & & . & • & 1 & 8 & 6 & 24 & 29 & 35 & 31 & 1 & & & & 135 \\
\hline $\begin{array}{ll}F_{1} & 2423 \\
2424\end{array}$ & $\begin{array}{l}7 \\
6\end{array}$ & $\begin{array}{l}6 \\
6\end{array}$ & $\begin{array}{l}2415 \\
2415\end{array}$ & & & & & . & & 1 & $\begin{array}{l}1 \\
1\end{array}$ & $\begin{array}{l}6 \\
2\end{array}$ & $\begin{array}{l}7 \\
7\end{array}$ & $\begin{array}{l}35 \\
35\end{array}$ & $\begin{array}{l}40 \\
29\end{array}$ & 3 & & & . & $\begin{array}{l}89 \\
78\end{array}$ \\
\hline $\mathrm{F}_{2} 2442$ & 6 & 6 & 2423 & & & & & & & 1 & & & 1 & 11 & 6 & 1 & & & 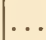 & 20 \\
\hline 2460 & 6 & 6 & 2423 & . & . & & . & & . & $\ldots$ & $\ldots$ & 5 & 3 & 46 & 33 & 2 & 1 & 1 & & 91 \\
\hline 2461 & 6 & 6 & 24 & & & & & & & 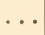 & ... & 2 & 2 & 38 & 35 & 1 & 2 & & & 80 \\
\hline 2462 & 5 & 5 & 2424 & 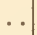 & & & . & & & $\cdots$ & $\cdots$ & $\cdots$ & 4 & 47 & 37 & 4 & .. & & & 92 \\
\hline 247 & 7 & 6 & 24 & & & & & & & 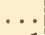 & $\cdots$ & $\ldots$ & 1 & 38 & 37 & 2 & .. & & & 78 \\
\hline 2473 & 6 & 6 & 2424 & & . & & & . & & 1 & .. & 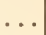 & 6 & 39 & 37 & 2 & 1 & . & . & 86 \\
\hline $\mathrm{F}_{3} 2496$ & 6 & 6 & 2442 & & . & & & & & $\cdots$ & & & . & 10 & 9 & 1 & 2 & & & 22 \\
\hline $\begin{array}{l}1303 \\
2503\end{array}$ & 6 & 7 & 2461 & & . & & & & & & & & 1 & 30 & 22 & 5 & 4 & 1 & I. & 63 \\
\hline 2517 & 6 & 7 & 24 & & & & & & & 1 & 2 & 12 & 5 & 30 & 35 & 2 & & & & 87 \\
\hline 2531 & 8 & 6 & 2460 & 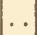 & .. & & . & .. & . & & & - & & 13 & 15 & 2 & 1 & . & 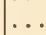 & 31 \\
\hline 2547 & 7 & 7 & 2 & & . . & & & 1 & & ... & 5 & 4 & 5 & 46 & 39 & 3 & $\cdots$ & 1 & & 104 \\
\hline 2548 & 6 & 6 & 2472 & & . & & & &. & 1 & 3 & 6 & 6 & 27 & 27 & .. & .. & .. & . . & 70 \\
\hline $\mathrm{F}_{4} 2570$ & 7 & 7 & 2503 & & & & & & & & 1 & 2 & 7 & 32 & 35 & 1 & 1 & & & 79 \\
\hline $\mathrm{F}_{5} 2654$ & 6 & 6 & 2570 & & & & & & 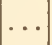 & 1 & 3 & 2 & 2 & 24 & 36 & 4 & 1 & & 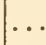 & 73 \\
\hline $\mathrm{F}_{6} 2758$ & 6 & 6 & 2654 & & & & & & & & & I & 2 & 13 & 12 & 1 & & & & 28 \\
\hline 2767 & 7 & 6 & 26 & & & & & & & 1 & & 3 & 3 & 28 & 24 & 1 & & 1 & & 61 \\
\hline 2768 & 7 & 6 & 2654 & . & . & & & & & . & $\ldots$ & 1 & 1 & 15 & 18 & 1 & 3 & 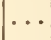 & . & 39 \\
\hline $\mathrm{F}_{7} 2851$ & 8 & 6 & 2767 & & & & & & & & & . & 1 & 17 & 21 & 1 & 1 & 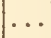 & $\ldots$ & 41 \\
\hline 2866 & 7 & 7 & 2768 &. & $\cdots$ & & & & & 2 & & 3 & .. & 27 & 19 & . &. & & & 51 \\
\hline $\mathrm{F}_{8} 2917$ & 6 & 6 & 2866 & & & & & & . . & 3 & & 3 & 2 & 29 & 36 & 4 & 2 & & & 79 \\
\hline
\end{tabular}

Table 28.-Crossbred Plus Series.

\begin{tabular}{|c|c|c|c|c|c|c|c|c|c|c|c|c|c|c|c|c|c|c|c|c|}
\hline \multirow{2}{*}{$\begin{array}{c}\text { Genera- } \\
\text { tion and } \\
\text { culture } \\
\text { No. }\end{array}$} & \multicolumn{2}{|c|}{ Mother. } & \multicolumn{2}{|c|}{ Father. } & \multicolumn{2}{|c|}{1} & 2 & \multicolumn{2}{|c|}{3} & \multicolumn{2}{|c|}{4} & \multicolumn{3}{|c|}{5} & \multicolumn{2}{|c|}{6} & \multicolumn{2}{|l|}{7} & 8 & \multirow{2}{*}{ हु } \\
\hline & Grade. & Culture. & Grade. & Culture. & \% & $\sigma^{2}$ & o & 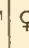 & $0^{2}$ & \% & $0^{\circ}$ & . & 8 & $0^{2}$ & 우 & $\sigma^{7}$ & 인 & $\sigma^{7} ?$ & $70^{2}$ & \\
\hline $\mathrm{F}_{3} \quad 937$ & 7 & Stock $^{1}$ & 6 & $902^{1}$ & & & & & 1 & & 2 & 9 & 4 & 9 & 15 & 13 & & & & 53 \\
\hline $\mathrm{F}_{4} 1040$ & 6 & 937 & 6 & 937 & & & & & & & 3 & 2 & 3 & 6 & 22 & 21 & 1 . & & & 58 \\
\hline $\begin{array}{l}1041 \\
1045\end{array}$ & 6 & 937 & 6 & 937 & 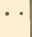 & & & & & & 3. & 1 & 4 & 3 & 38 & 45 & 1 & 2 & & 97 \\
\hline $\begin{array}{l}1045 \\
1067\end{array}$ & $\begin{array}{l}6 \\
6\end{array}$ & $\begin{array}{l}926^{1} \\
937\end{array}$ & $\begin{array}{l}6 \\
6\end{array}$ & $\begin{array}{l}1004^{1} \\
937\end{array}$ & . & & & & & 4 & & $\begin{array}{l}8 \\
3\end{array}$ & $\begin{array}{c}29 \\
16\end{array}$ & $\begin{array}{l}30 \\
15\end{array}$ & $\begin{array}{l}35 \\
17\end{array}$ & $\begin{array}{r}22 \\
8\end{array}$. & 1 . & $\cdots$ & & · $\begin{array}{r}198 \\
64\end{array}$ \\
\hline $\mathrm{F}_{5} 1074$ & 6 & $1006^{1}$ & 6 & Stock ${ }^{1}$ & & & & & & & & & 25 & 30 & 34 & 31 & 1 & & & 172 \\
\hline 1090 & 6 & 1041 & 7 & 1041 & & & & & & & & & 2 . & & 23 & 17 & 1 & 3 & & i) 47 \\
\hline 1099 & 6 & 1041 & 6 & 1041 & & & & & & & 9 & 4 & 12 & 15 & 34 & 30 & 2 & 1 & & 107 \\
\hline 1100 & 7 & 1045 & 6 & 1041 & & & & & & & 8 & 6 & 11 & 16 & 40 & 34 & 2 & 3 & & 120 \\
\hline 1101 & 6 & 1045 & 6 & 1045 & & & & & & & \begin{tabular}{l|l}
6 & 1 \\
\end{tabular} & 0 . & 12 & 19 & 31 & 28 & 3 &. & & 111 \\
\hline 1115 & 6 & 1041 & 6 & 1041 & & & & & & & & & 9 & 5 & 28 & 45 . & $\cdots$ & .. & & .87 \\
\hline 1116 & 6 & 1045 & 6 & 1045 & & & & & & & & 5 & 15 & 17 . & 27 & 23 & 1 . & .. & . & . 98 \\
\hline 1144 & 6 & 1067 & 6 & 1041 & & & & & & & & 1 & 1 & 2 & 8 & 9 & 1 . & . & 1 & \begin{tabular}{l|l}
1 & 23 \\
1
\end{tabular} \\
\hline 1145 & 7 & 1041 & 6 & 1045 & & & & & & & 2 & 3 & 4 & 6 & 17 & 15 & & & ${ }^{2} 1$ & $1 \mid 47$ \\
\hline
\end{tabular}

${ }^{1}$ Unselected, or from inbred plus series.

${ }^{2}$ This is probably the original extended mutant. Not included in totals. 
Table 28.-Crossbred l'lus Sermis-Continuel.

\begin{tabular}{|c|c|c|c|c|c|c|c|c|c|c|c|c|c|c|c|c|c|c|c|c|}
\hline \multirow{2}{*}{$\begin{array}{c}\text { Genera- } \\
\text { tion and } \\
\text { culture } \\
\text { No. }\end{array}$} & \multicolumn{2}{|c|}{ Mother. } & \multicolumn{2}{|c|}{ Father. } & \multicolumn{2}{|c|}{1} & \multicolumn{2}{|c|}{2} & \multicolumn{2}{|c|}{3} & \multicolumn{2}{|l|}{4} & \multicolumn{2}{|l|}{5} & n & & 7 & & s & \\
\hline & Grade. & Culture. & Grade. & Culture. & ? & $\sigma^{2}$ & ? & $\sigma^{7}$ & १ & $\sigma$ & 8 & $\sigma^{x}$ & \& & $0^{*}$ & 8 & $\sigma^{\prime \prime}$ & $8 \%$ & $3^{2} ?$ & ? & Fis \\
\hline$F_{6} 1129$ & 6 & 1045 & 6 & 1074 & & & & & & 1 & 2 & 2 & $1: 3$ & 14 & 40 & 52 & 1 & & & 134 \\
\hline $\begin{array}{l}16 \\
6130\end{array}$ & 6 & 1074 & 6 & 1045 & & & & & & & 3 & 4 & 11 & 15 & $\begin{array}{l}4.1 \\
25\end{array}$ & 24 & 1 & & & 83 \\
\hline 1131 & 6 & 1074 & 7 & 1041 & & & & & & & & 1 & 14 & 13 & 25 & 25. & 1 & 2 & & so \\
\hline 1146 & 7 & 1074 & 6 & 1074 & & & & & & & & 1 & 2 & 1 & 16 & (9) & 2 & 1 & & 32 \\
\hline 1151 & 6 & $1072^{1}$ & 6 & $1081^{1}$ & & & & & & & 1 & 3 & 4 & 11 & 16 & 17 & & i & & 5.3 \\
\hline 1171 & 7 & 1099 & 7 & 1090 & & & & & & & & & & 1 & 22 & $2 k$ & 6 & 3 & & 60 \\
\hline 1187 & 7 & 1090 & 7 & 1100 & & & & & & & 1 . & & 1 & 1 & 14 & 11 & & 11 & & 30 \\
\hline 1188 & 7 & 1101 & 7 & 1100 & & & & & & & 1 & 3 & $\dot{x}$ & 10 & 44 & 25 & 1 & & & 96 \\
\hline 1190 & 7 & 1101 & 7 & 1090 & & & & & & & 1 & 1 & 15 & 10 & 60 & $4: 3$ & 1 & 3 & & 13.1 \\
\hline 1196 & 7 & 1100 & 7 & 1100 & & & & & & 1 & .. & 1 . & & 3 & 26 & 12 & 5 & 2 & & 50 \\
\hline 1197 & 6 & 1115 & 6 & $1081^{1}$ & & & & & & & & 1. & 5 & 3 & 19 & 14 & 2 & 1 & & 45 \\
\hline 1204 & 7 & 1116 & 8 & 1090 & & & & & & & 5 & 6 & 17 & 4 & 40 & 25 & 3 & 1 & 11 & 102 \\
\hline 1227 & 6 & 1101 & 6 & 1115 & & & & & & & 1 & 1 & 2 & 5 & 63 & 53 & 2 & 41 & 1 & 132 \\
\hline $\mathrm{F}_{7} 1198$ & 7 & 1101 & 6 & 1131 & $\therefore$ & & & & 1 & 2 & 2 & 3 & 10 & 8 & 26 & 23 . & & & & $\div 5$ \\
\hline 1203 & 7 & 1130 & 7 & 1099 & & & & & & & & & 1 & & 1 & 6 & 4 & i & & 13 \\
\hline 1253 & 7 & 1146 & 6 & 1131 & & & & & & 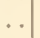 & $\lambda$ & 3 & 9 & 5 & 22 & 24 & 4 & 1 & 2 & 78 \\
\hline 1254 & 7 & 1129 & 6 & 1115 & & & & & & & 1 . & & 1 & & 3 & 8 & 2 & 1 & & 16 \\
\hline 1262 & 6 & 1151 & 6 & 1144 & & & & & & & 1 . & & 5 & 2 & 24 & 21 & 5 & & & 53 \\
\hline 1269 & 7 & 1171 & 6 & 1129 & & & & & & & 3 & 3 & 5 & 5 & 20 & 5 & 2 & 2 & & 45 \\
\hline 1271 & 6 & 1190 & 7 & 1131 & & & & & & & & & .. & 2 & 8 & 8 & 2 & & & 20 \\
\hline 1284 & 7 & 1188 & 7 & 1171 & & & & & & & 2. & & 8 & 8 & 25 & 23 & & 1 & & 67 \\
\hline 1285 & 7 & 1171 & 7 & 1190 & & & & & & . & 2 & 1 & 5 & 3 & 20 & 19 & 3 & 1 & & 54 \\
\hline 1293 & 7 & 1190 & 6 & 1151 & & & & & & & & 2 & 2 & 7 & 35 & 24 & 3 & 1 & 3 & 77 \\
\hline 1304 & 6 & 1151 & 7 & 1157 & & & & & & 4 & 6 & 6 & 8 & $\tau$ & 13 & 11 & & 2 & & 57 \\
\hline 1324 & 7 & 1204 & 7 & 1171 & & & & & 1 & & 5 & 2 & 8 & 11 & 29 & 23 & 2 & 1 & & 82 \\
\hline 1325 & 7 & 1171 & 6 & 1227 & & & & & & & 3. & & 4 & 5 & 28 & 20 & 1 & 1 & & 62 \\
\hline 1326 & 7 & 1171 & 6 & 1190 & & & & & & & 1 & 1 & 6 & 3 & 40 & 18 & 2 & 4 & & 75 \\
\hline 1333 & 7 & 1227 & 6 & 1188 & & & & & & & & & & & 14 & 20 & 1 . & & & 35 \\
\hline 1345 & 7 & 1227 & 6 & 1190 & & & & & & & 2 & 7 & 9 & 7 & 39 & 34 & 1 & 1 & & 100 \\
\hline 1353 & 7 & 1204 & 7 & 1227 & & & & & & 1] & 1 & 2 & 7 & o & 3. & 33 & 1 & 1 & & 92 \\
\hline $1305^{2}$ & Not D' & 1197 & 8 & 1090 & & & & 1 & & & 6 & 3 & 8 & 6 & 10 & 9 & & & & 43 \\
\hline$F_{8} 1334$ & 8 & 1227 & 7 & 1203 & & & & & & & 17 & 11 & 17 & 17 & 41 & 42 & 3 & & & 145 \\
\hline 1346 & 7 & 1203 & 6 & 1204 & & & & & & & 7 & 5 & 11 & 9 & 32 & 22 & & 1 & & 87 \\
\hline 1351 & 7 & 1196 & 6 & 1203 & & & & & & & & & $\ldots$ & & 5 & 6 . & & 1 & & 12 \\
\hline 1356 & 8 & 1253 & 7 & 1227 & & & & & & & & & & & 6 & 9 & 2 & 3 & & 20 \\
\hline 1357 & 7 & 1253 & 6 & 1203 & & & & & & & 1 & 4 & 5 & 6 & 18 & 21 & 1 & 1 & & 57 \\
\hline 1359 & 7 & 1203 & 6 & 1204 & & & & & & . & t & . . & 5 & 4 & 17 & 16 & 1 & 1 & & 44 \\
\hline 1360 & 7 & 1203 & 7 & 1227 & & & & & & & & & 1 & 2 & 6 & 3. & & & & 12 \\
\hline 1372 & 7 & 1254 & 6 & 1204 & & & & & & & 4 & 6 & 1 & 6 & 5 & 6. & & & & $2 s$ \\
\hline 1373 & 7 & 1196 & 7 & 1254 & & & & & & & & & 1 & & 19 & 17 & 3 & 3 & 1 & 44 \\
\hline $1380^{2}$ & 7 & 1262 & 8 & 1090 & & & & & & 2 & 12 & 15 & 5 & 9 & 6 & $\therefore$ & & & & 57 \\
\hline 1425 & 7 & 1271 & 7 & 1304 & & & & & & & 14 & 6 & 19 & 13 & 39 & 33 & & & & 124 \\
\hline 1426 & 7 & 1293 & 7 & 1304 & & & & & & & ... & & 1 & 2 & 12 & 15 & 2 & 2 & & 34 \\
\hline 1427 & 7 & 1285 & 7 & 1284 & & & & & & & 3 & 3 & 5 & 3 & 29 & 16 & 4 & 1 & 2 & 66 \\
\hline 1428 & 7 & 1262 & 7 & 1293 & & & & & & & . & & & & 4 & 1 & 2 & & & $i$ \\
\hline 1429 & 7 & 1269 & 8 & 1293 & & & & & & & & 2 & 2 & 8 & 29 & $2 \pi$ & 2 & 1 & & il \\
\hline 1458 & 7 & 1345 & 7 & 1285 & & & & & & & 2 . & & t & 2 & 25 & 37 & 1 & $4: 2$ & & .3.3 \\
\hline $\mathrm{F}_{9} 1457$ & 7 & 1334 & 7 & 1345 & & & & & & & & & & 1 & 14 & is & 2 & 4 & & 39 \\
\hline 1492 & 7 & 1334 & 7 & 1351 & & & & & & & & & & & 4 & 1 & 3 & & & 8 \\
\hline 1496 & 7 & 1359 & 7 & 1346 & & & & & & 1 & 13 & 5 & 24 & 10 & as & 4.4 & $\tilde{\imath}$ & & & 160 \\
\hline 1497 & 7 & 1326 & 7 & 1356 & & & & & & & 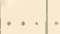 & . & 2 & & 5 & 2 & 2 & 11 & & 13 \\
\hline 1501 & 7 & 1356 & 6 & 1333 & & & & & & & & & & & 12 & 14 & 2 & 2 & 1 & 31 \\
\hline 1538 & 7 & 1356 & 7 & 1359 & & & & & & & & & 1 . & & 16 & 16 & 3 & 21 & 1 & 40 \\
\hline 1541 & 7 & 1326 & 7 & 1357 & & & & & & & & & 1 . & & 9 & 6 & 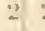 & A) & & $\because 0$ \\
\hline 1612 & 7 & $142 S$ & 7 & 1426 & & & & & & & 2 & 2 & (i) & ; & 41 & 23 & 4 & & & 45 \\
\hline$F_{10} 1581$ & 7 & 1457 & 7 & $13 \pi 3$ & & & & & & & & & & & 15) & 21 & 3 & & & 42 \\
\hline 1599 & 7 & 1492 & 8 & 137.3 & & & & & & 1 & 7 & 1 & 15 & 14 & 39 & $4 \pi$. & & 3 & & $12 \%$ \\
\hline 1709 & 8 & 1458 & 7 & 1538 & & & & & & & & & 1. & .. & 10 & 13 & 3 & I & & 25 \\
\hline 1758 & 7 & 1612 & 8 & 1538 & & & & & & & & 1 & 1 & 2 & 22 & 11 & 1 & $1 \ldots$ & & 39 \\
\hline
\end{tabular}


Table 29.-Inbred Minus Series. 900 Line.

\begin{tabular}{|c|c|c|c|c|c|c|c|c|c|c|c|c|c|c|c|c|c|c|c|c|}
\hline \multirow{2}{*}{$\begin{array}{c}\text { Genera- } \\
\text { tion and } \\
\text { culture } \\
\text { No. }\end{array}$} & \multicolumn{3}{|c|}{ Parents. } & \multicolumn{2}{|c|}{1} & \multicolumn{2}{|c|}{2} & & \multicolumn{2}{|c|}{4} & & \multicolumn{2}{|c|}{6} & & & \multirow[b]{2}{*}{ 豞 } \\
\hline & & $\frac{0^{7}}{19}$ & $\begin{array}{l}\text { Cul- } \\
\text { ture. }\end{array}$ & 웅 & $0^{x}$ & 운 & $\sigma^{2}$ & q & $\sigma^{7}$ & q & $0^{7}$ & 9 & $0^{7}$ & ? & $\sigma^{2}$ & ㅇ & $\sigma^{7}$ & q & $\sigma^{x}$ & \\
\hline $\begin{array}{ll}\mathrm{F}_{1} & 920 \\
& 922\end{array}$ & $\begin{array}{l}4 \\
4\end{array}$ & $\begin{array}{l}4 \\
4\end{array}$ & $\begin{array}{l}900 \\
900\end{array}$ & & & & 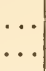 & & $\cdots$ & $\begin{array}{r}23 \\
8\end{array}$ & $\begin{array}{l}16 \\
10\end{array}$ & $\begin{array}{r}19 \\
8\end{array}$ & $\begin{array}{r}10 \\
9\end{array}$ & $\begin{array}{r}12 \\
5\end{array}$ & & & & & & \\
\hline $\begin{array}{ll}\mathrm{F}_{2} & 1007 \\
1008\end{array}$ & 4 & $\begin{array}{l}4 \\
4\end{array}$ & $\begin{array}{l}920 \\
922\end{array}$ & & & & 1 & & 1 & $\begin{array}{l}26 \\
31\end{array}$ & $\begin{array}{l}35 \\
20\end{array}$ & $\begin{array}{l}18 \\
11\end{array}$ & $\begin{array}{l}14 \\
11\end{array} \mid$ & $\begin{array}{r}18 \\
9\end{array}$ & & & & & & $\begin{array}{r}116 \\
88\end{array}$ \\
\hline $\begin{array}{ll}F_{3} & 1062 \\
1063\end{array}$ & 4 & $\begin{array}{l}4 \\
4\end{array}$ & & & & & & & 2 & $\begin{array}{l}21 \\
16\end{array}$ & $\begin{array}{l}21 \\
13\end{array}$ & $\begin{array}{r}7 \\
10\end{array}$ & $\begin{array}{r}11 \\
8\end{array}$ & 7 & & & 11 & & & 71 \\
\hline & & 2 & 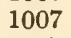 & & & & & & 2 & 26 & 27 & $\begin{array}{l}19 \\
\end{array}$ & 12 & 4 & 12 & & & & & $\begin{array}{r}52 \\
102\end{array}$ \\
\hline 10 & 4 & 4 & 1008 &. & & . & & & 1 & 7 & 4 & 9 & 5 & 1 & 3 & 1 & & & .. & [- \\
\hline $\mathrm{F}_{4} \begin{array}{l}1134 \\
1135\end{array}$ & 4 & 4 & 106 & 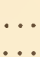 & & & & & i & $\begin{array}{l}7 \\
8\end{array}$ & $\begin{array}{r}13 \\
8\end{array}$ & $\begin{array}{l}15 \\
12\end{array}$ & $\begin{array}{r}11 \\
8\end{array}$ & $\begin{array}{r}23 \\
2\end{array}$ & 14 & & & & & \\
\hline 11 & 4 & 4 & 1063 & & & & & & 1 & 10 & 17 & $\begin{array}{l}12 \\
15\end{array}$ & $\begin{array}{l}8 \\
9\end{array}$ & $\begin{array}{r}2 \\
12\end{array}$ & $\begin{array}{l}4 \\
4\end{array}$ & & & & & \\
\hline $\mathrm{F}_{5} 1258$ & 4 & 4 & 1 & & & & & & & 1 & 1 & 3 & 5 & 14 & 11 & 1 & & & & 36 \\
\hline 125 & & 4 & & & & & & & & 18 & 14 & 17 & 13 & 17 & 2 & & 1 & & & \\
\hline & 4 & 3 & & & & & & & $\cdots$ & 14 & 6 & 13 & 7 & 13 & 10 & 1 & & & & \\
\hline 12 & & 4 & 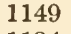 & & & & & . & & 3 & 1 & 6 & 3 & 3 & 2 & & & & & 18 \\
\hline 1 & 4 & 4 & 1 & & & & & . . & 1 & & 10 & 5 & 5 & 7 & & & & & & \\
\hline$F_{6} 1391$ & 4 & 4 & 1. & & & 1 & 5 & 3 & 6 & 10 & 11 & 7 & 11 & 6 & 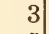 & & & & .. & 63 \\
\hline 14 & 4 & 4 & & & & & & & .. & 1 & 6 & 6 & 7 & 15 & 5 & & & & & 40 \\
\hline $\mathrm{F}_{7} 156$ & 4 & 2 & 139 & & & & & & 1 & 9 & 11 & 5 & 12 & 3 & 4 & & & & & 45 \\
\hline & & $\begin{array}{l}3 \\
3\end{array}$ & & & & & & & & $\begin{array}{l}2 \\
3\end{array}$ & & & & 4 & 1 & & & & & \\
\hline 1 & & 2 & & & & & & & .. & 3 & 1 & $\begin{array}{l}4 \\
2\end{array}$ & 4 & $\begin{array}{r}10 \\
3\end{array}$ & 3 & & & & & 13 \\
\hline 1 & 3 & 3 & 1 & & & & & & $\cdots$ & 8 & 6 & 13 & 10 & 20 & 3 & & & & & 60 \\
\hline $\mathrm{F}_{8} 167$ & 6 & 6 & 1565 & & & & & & 1 & 6 & 9 & 5 & 8 & 8 & 6 & & & & . & 43 \\
\hline-81 & 4 & 4 & & & & & & & 1 & 7 & 5 & 2 & 6 & 3 & 2 & & & & $\cdots$ & 26 \\
\hline 179 & 4 & 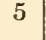 & 157 & & & & 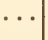 & - & 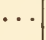 & 1 & 1 & 4) & 1 & & .. & & . & & .. & 7 \\
\hline $\mathrm{F}_{9} 185$ & 4 & 4 & & & & & &. & 2 & 16 & 20 & 17 & 6 & 5 & 3 & & & & . & 69 \\
\hline 1 & & 3 & & & & & & $\cdots$ & 1 & 14 & 11 & & 7 & 4 & 3 & & & & . & 51 \\
\hline & & 5 & & & & & 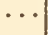 & & & 11 & 7 & 0 & & 4 & & & & & $\cdots$ & 37 \\
\hline $\begin{array}{l}1 \\
1\end{array}$ & 4 & & & & & & & . & 3 & 23 & 23 & 16 & 18 & 7 & ] & & 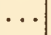 & & $\cdots$ & 1 \\
\hline & 4 & 3 & & & & & & & 1 & 5 & 5 & 5 & 2 & 3 & 2 & & . & & . & \\
\hline $\begin{array}{l}1995 \\
2008\end{array}$ & 4 & 4 & 18 & & & & & & & 6 & 9 & 6 & 5 & 1 & 3 & & & & . . & 30 \\
\hline & & 3 & & & & & ... & & 3 & 19 & 19 & 13 & 10 & 3 & 5 & & & & & 72 \\
\hline & & & & & & & & & 1] & 14 & 23 & 4 & & & & & & & * & 18 \\
\hline & & 4 & & & & & 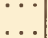 & & 1 & 6 & 7 & 4 & & 2 & 2 & & & & . & 1 \\
\hline & & & & & & & i) & & 3 & 19 & 18 & 13. & 16 & & 6 & & & & $\cdots$ & 31 \\
\hline & & 4 & & & & & $\ldots$ & & 1 & $\begin{array}{r}18 \\
5\end{array}$ & $\begin{array}{r}11 \\
8\end{array}$ & 8 & & & 3 & & & & . & 33 \\
\hline & 4 & 4 & & & & & & & .. & 2 & & 2 & & & 4 & & & & & $\begin{array}{l}33 \\
13\end{array}$ \\
\hline & & & & & & & & & 1 & 15 & 17 & 1 & 8 & 10 & 7 & & & & & 69 \\
\hline & 4 & 4 & & & & & & & 1 & 14 & 12 & 6 & 6 & 4 & 2 & & 1 & & & 46 \\
\hline & & & & & & & $\because$ & & & 9 & 14 & 9 & 6 & 3 & 4 & & & & & 45 \\
\hline & & 4 & & & & & 1 & & 1 & 13 & 1 & 5 & & & & & & & & 11 \\
\hline & & & & & & & $\cdots$ & & 2 & 12 & 1 & 7 & 0 & t & 1 & & & & & 38 \\
\hline & & 4 & & & & & & & 3 & 19 & 19 & & & & & & & & & 54 \\
\hline & & & & & & & & & 1 & & 1 & 10 & 1 & 4 & & & & & & 10 \\
\hline & & 3 & & & & & & & 3 & 16 & 8 & 10 & 6. & & ? & & & & & 45 \\
\hline & & 3 & & & & & & & & 8 & 2 & 4 & 11 & 4 & 4 & & & & & 33 \\
\hline 2128 & 4 & 3 & 1930 & & & & & & & 4 & 10 & 4 & 5 & 4 & 1 & & & & & 28 \\
\hline ก & & 4 & & & & & & & & 5 & 5 & 6 & 4 & 11 & & & & & & 39 \\
\hline 2 & 4 & 4 & & & & & & & 1 & 1 & 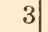 & 8 & 10 & 5 & 11 & & & & & 39 \\
\hline & & & & & & & & & & 18 & 18 & 9 & 12 & 5 & & & & & & 67 \\
\hline & 4 & 4 & & & & & & & & 1 & 7 & 6 & 5 & 11 & 10 & 2 & 3 & & & 45 \\
\hline & & 3 & & & & & & & & 11 & 3 & I & & 8 & & & & & & 43 \\
\hline & & 3 & & & & & & & & 3 & 1 & 2 & & (1) & & & & & & 24 \\
\hline & & 3 & & & & & & & & & & & & 1 & & & & & & 21 \\
\hline & & 2 & & & & & & & & 1 & & 5 & & f & 3 & & & & & 17 \\
\hline & & 4 & & & & & & & & 4 & 4 & 4 & & 2 & & & & & & 17 \\
\hline & & 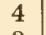 & & & & & & & & & 1 & A & & 5 & . & & & & & 15 \\
\hline 2261 & 4 & 3 & 2037 & & & & & & & 3 & 2 & 2 & 1 & 1 & 3 & 1 & & & & 13 \\
\hline
\end{tabular}


Table 30.-Inbred Minus Series. SGS Line.

\begin{tabular}{|c|c|c|c|c|c|c|c|c|c|c|c|c|c|c|c|c|c|c|c|c|}
\hline \multirow{2}{*}{$\begin{array}{c}\text { Genera- } \\
\text { tion and } \\
\text { culture } \\
\text { No. }\end{array}$} & \multicolumn{3}{|c|}{ Parents. } & \multicolumn{2}{|c|}{1} & & \multicolumn{2}{|c|}{3} & & \multicolumn{2}{|l|}{5} & \multicolumn{2}{|l|}{6} & & \multicolumn{2}{|c|}{8} & \multirow[b]{2}{*}{ इ } \\
\hline & $\frac{\text { Gra }}{q}$ & $d$ & $\begin{array}{l}\text { Cul- } \\
\text { ture. }\end{array}$ & q & $0^{7}$ & \% & $\sigma^{x}$ & 9 & $0^{x}$ & $\%$ & $\sigma^{\pi}$ & $\%$ & $\sigma^{7}$ & \% & $\sigma^{x}$ & $q$ & $0^{\pi}$ & q & $0^{7}$ & \\
\hline$F_{1} 88$ & 4 & 4 & 868 & & & ${ }^{1} 1$ & & ${ }^{1} 6$ & & 138 & & ${ }^{1} 15$ & & ${ }^{1} 11$ & & & & & & 74 \\
\hline $\mathrm{F}_{2} \quad 898$ & 4 & 2 & 8 & & & & & ${ }^{1} 1$ & & ${ }^{1} 56$ & & 125 & & $3_{24}$ & & & & & & I00 \\
\hline $\begin{array}{rr}\mathrm{F}_{3} & 923 \\
& 935 \\
& 936\end{array}$ & $\begin{array}{l}4 \\
4\end{array}$ & $\begin{array}{l}4 \\
4\end{array}$ & 8 & & 1 & 1 & $\begin{array}{l}2 \\
7 \\
.\end{array}$ & $\begin{array}{r}2 \\
\cdots \\
1\end{array}$ & $\begin{array}{r}2 \\
10 \\
\ldots\end{array}$ & $\begin{array}{r}32 \\
39 \\
1\end{array}$ & $\begin{array}{r}31 \\
22 \\
1\end{array}$ & $\begin{array}{r}10 \\
5 \\
1\end{array}$ & $\begin{array}{r}11 \\
5\end{array}$ & $\begin{array}{l}6 \\
2 \\
1\end{array}$ & $\begin{array}{l}4 \\
1\end{array}$ & & & & & 100 \\
\hline $\mathrm{F}_{4} 1047$ & 2 & 2 & 935 & & ... & 1 & 3 & 2 & 14 & 24 & 18 & 3 & 1 . & 1 & . & & & & & 68 \\
\hline$F_{5} 11$ & $\begin{array}{l}4 \\
4\end{array}$ & $\begin{array}{l}3 \\
3\end{array}$ & & & & 1 & & 1 & 3 & $\begin{array}{r}8 \\
34\end{array}$ & $\begin{array}{r}3 \\
10\end{array}$ & 6 & $\begin{array}{l}4 \\
8\end{array}$ & $\begin{array}{l}2 \\
1\end{array}$ & 1 & & & & & \\
\hline $\mathrm{F}_{6} 1257$ & 4 & 4 & 1117 & & & & & - & 2 & 8 & 4 & 5 & 1 & 1 & & & & & & 2 \\
\hline
\end{tabular}

${ }^{2}$ Sexes not separated in this count.

Table 31.-Crossbred Minus Series.

\begin{tabular}{|c|c|c|c|c|c|c|c|c|c|c|c|c|c|c|c|c|c|c|c|c|}
\hline \multirow{2}{*}{$\begin{array}{l}\text { Genera- } \\
\text { tion and } \\
\text { culture } \\
\text { No. }\end{array}$} & \multicolumn{2}{|c|}{ Mother. } & \multicolumn{2}{|c|}{ Father. } & \multicolumn{2}{|c|}{1} & \multicolumn{2}{|l|}{2} & \multicolumn{2}{|c|}{3} & \multicolumn{2}{|l|}{4} & \multicolumn{2}{|l|}{5} & \multicolumn{2}{|l|}{6} & 7 & \multicolumn{2}{|c|}{8} & \multirow{2}{*}{-} \\
\hline & Grade. & Culture. & Grade. & Culture. & $\%$ & $0^{7}$ & 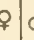 & $\sigma^{x}$ & 70 & $\sigma^{7}$ & 웅 & $0^{7}$ & ᄋ & $\sigma^{\pi}$ & \% & $\sigma^{\pi}$ & 80 & \% & $\sigma^{7}$ & \\
\hline 1039 & 4 & 1920 & 4 & ${ }^{1936}$ & & & & 1 . & & 3 & 38 & 61 & 16 & 21 & 5 & 5 & & & & 150 \\
\hline 41 & 4 & & 4 & & & & & . & & 1 & 28 & 11 & 10 & 14 & 8 & 6 & i & & & 100 \\
\hline 1070 & 4 & 19 & 4 & 1942 & & & & & 1 . & & 25 & 20 & 21 & 11 & 10 & 6 & & & & 9. \\
\hline $\mathrm{F}_{5} 1087$ & 4 & 1039 & 4 & 1039 & & & & 2 . & & 4 & 59 & 43 & 10 & 15 & 2 & 4 & & & & 139 \\
\hline 1093 & 4 & & 2 & & & & & . & & 4 & 35 & 32 & 9 & 11 & 2 & 4 & & & & 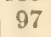 \\
\hline 10 & 4 & & 3 & & & & &. & & 1 & 3 & 6 & 7 & 4. & & 2 & & & & 2 \\
\hline 11 & 4 & & 2 & & & & & 2. & & 12 & 40 & 26 & 9 & 6 & 2 & 6 & & & & 103 \\
\hline 11. & 4 & & 4 & & & & & & 1 & 2 & 36 & 27 & 5 & 11 & 1 & 1 & & & & 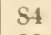 \\
\hline 1. & 4 & & 3 & & & & & 7 . & & 19 & 42 & 26 & 9 & 9 & 9 & 2 & & & & 123 \\
\hline & 4 & & 4 & 107 & & .. & . & $\cdots$ & & 1 & 10 & 7 & 14 & 12 & 8 & 1 & 1 . & & & 5 \\
\hline 1. & 4 & & 4 & 10 & & . & & & & 2 & 13 & 12 & 4 & 4 & 1 & 5 & & & & 4 \\
\hline 1159 & 4 & 1070 & 3 & $1073^{1}$ & & & & & & 7 & & 3 & 7 & 5 & 7 & 2 & & & & \\
\hline$F_{6} 1168$ & 4 & $1082^{1}$ & 4 & 1093 & & & & & & & 11 & 13 & 10 & 10 & 9 & $\delta$ & & & & 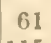 \\
\hline$x_{1}$ & 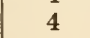 & & 3 & 10 & & & i) & & & 3 & 41 & 31 & 11 & 15 & 10 & 2 & 1 & & & 11 \\
\hline & 4 & 1093 & 3 & 106 & & & & & & .. & 1 . & & 3 & 1 & 1 & 5 . & & & & \\
\hline & 3 & & 3 & & & & & & & & 29 & 17 & 12 & 16 & s & 10 . & & & & \\
\hline & 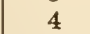 & & 3 & 109 & & . & & & & i & 22 & 20 & 11 & 10 & 1 & 4. & & & & \\
\hline & 4 & 1 & 3 & 11 & & & & 3 & 1 & 3 & 32 & 19 & 10 & 7 & 3 & 1 & & & & \\
\hline & 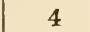 & & 3 & & & & & & & 1 & 10 & 9 & 12 & 6 & 16 & 6 . & & & & \\
\hline & $\Psi$ & & 2 & ic & & & & & & 1 & 9 & 7 & 11 & 8 & 3 & 3 . & & & & \\
\hline & 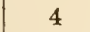 & & 3 & & & & & & & 1 & 21 & $2 s$ & 14 & 9 & 10 & 2. & & & & \\
\hline & 4 & & 3 & ic & & & & & & & is & 6 & 13 & 2 & 4 & 5. & & & & \\
\hline & 4 & & 3 & & & . & & & & & 12 & 21 & $6^{\prime}$ & 5 . & & 1 & 1 & & & \\
\hline 12 & 4 & & 2 & 11 & & & & & & 1 & 13 & 5 & 6 & 7 & 9 & 7 & & & & \\
\hline & $\boldsymbol{\Psi}$ & & 4 & & . & & & & & 1 & $2 \pi$ & 13 & 10 & 17 & 17 & 6 . & & & & \\
\hline & $\Psi$ & & 2 & 11 & & & & 1 . & & 4 & 25 & 16 & 11 & 14 & 3 & 6. & & & & 8 \\
\hline & 3 & & 2 & 11 & & & & & & & 11 & 3 & 17 & 8 & 17 & 5. & & & & \\
\hline 1268 & 4 & 1136 & 3 & 1125 & & & & & & & & 5 & 5 & of & & 9 & & & & \\
\hline
\end{tabular}

${ }^{1}$ Unselected, or from inbred minus series. 
Table 31.-Crossbred Minus Series-Continued.

\begin{tabular}{|c|c|c|c|c|c|c|c|c|c|c|c|c|c|c|c|c|c|c|c|c|c|}
\hline \multirow{2}{*}{$\begin{array}{l}\text { Genera- } \\
\text { tion and } \\
\text { culture } \\
\text { No. }\end{array}$} & \multicolumn{2}{|c|}{ Mother. } & \multicolumn{2}{|c|}{ Father. } & \multicolumn{2}{|c|}{1} & \multicolumn{2}{|c|}{2} & 3 & & 4 & & 5 & & 6 & & & 7 & 8 & 8 & \\
\hline & Grade. & Culture. & Grade. & Culture. & \% & $\sigma^{2}$ & q & $0^{2}$ & ९ & $\sigma^{3}$ & 웅 & $0^{7}$ & q & $0^{\pi}$ & q & $\sigma^{7}$ & क & $\sigma^{7}$ & \% & $\sigma^{2}$ & \\
\hline $\mathrm{F}_{-} 1256$ & 4 & 1168 & 3 & 1140 & & & & & & 1 & 8 & 9 & 21 & 16 & 12 & 17 & & & & & \\
\hline 1273 & 4 & 5 & 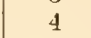 & & & & & $i$ & i) & 8 & 33 & 18 & 8 & 13 & $\begin{array}{r}12 \\
3\end{array}$ & 12 & & & & & $\begin{array}{l}84 \\
97\end{array}$ \\
\hline 1274 & 4 & 1168 & 2 & 1140 & & & & & & 2 & 26 & 25 & 7 & 12 & 4 & 4 & & & & & \\
\hline 1292 & 4 & 1199 & 4 & 1168 & . & & & & 1 & 6 & 61 & 43 & 14 & 5 & 1 . & & & & & & 131 \\
\hline 1300 & 4 & 1194 & 4 & 1169 & .. & & & & & 2 & 21 & 13 & 13 & 12 & 5 & 4 & & & & & 70 \\
\hline 1301 & 4 & 1169 & 4 & 8 & & & & & & 4 & 21 & 13. & 9 & 6 & 1 & 1 & & & & & 55 \\
\hline 1316 & 4 & 1194 & 4 & 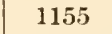 & & & & & & 7 & 41 & 34 & 6 & 9 & 5 & 2 & & . & & & 104 \\
\hline 1317 & 4 & 1 & 3 & 69 & & & & & 1 & 3 & 18 & 7 & 1 & 3 & 1 & 1 & & & & & 35 \\
\hline 1321 & 4 & 1194 & 3 & 1199 & & & & & 1 & 3 & 17 & 16 & 13 & 4 & 5 & 5 & & . & & & 04 \\
\hline 1371 & 4 & & 4 & 119 & . & & & & & 2 & 29 & 30 & 18 & 9 & 3 & 5 & & & & & \\
\hline 13 & 4 & 124 & 4 & 10 & .. & & & 1 & & 5 & 30 & 19 & 4 & 10 & 2 & 3 & & & & & 14 \\
\hline 1 & 4 & & 4 & & & & & 1 & & 2 & 16 & 16 & 4 & 3 & 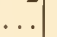 & 1 & & & & & \\
\hline 1395 & 4 & 1241 & 4 & 1243 & & & & 1 & & 3 & 21 & 16 & 4 & 1 & 3 & 2 & & & & & 51 \\
\hline 13 & 4 & 1 & 4 & 1241 & . . & & & 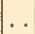 & & 1 & 14 & 15 & 8 & 2 & 1 & 1 & & . & & & 42 \\
\hline 1397 & 4 & 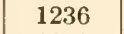 & 3 & 1242 & & & & & & $\because$ & 20 & 12 & 8 & 7 & 5 & 2 & & & & & \\
\hline 14 & 4 & 1 & 3 & 1242 & . . & & & .. & & 1 & 39 & 18 & 13 & 12 & 4 & 12 & & . & & & 99 \\
\hline 1411 & 4 & 124 & 3 & 12 & . . & & & 1 & & 10 & 41 & 27 & 11 & 5 & 1. & 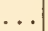 & & & & & 96 \\
\hline 141 & 4 & 12 & 4 & 1224 & . . & & & 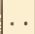 & 1 & 4 & 31 & 21 & 12 & 11 & 2 . & & & . & & & 82 \\
\hline 1433 & 4 & 1243 & 4 & 12 & . . & & & & 1 & 6 & 53 & 26 & 8 & 14 & 3 & 5 & & . & & & 116 \\
\hline $\mathrm{F}_{8} 1413$ & 4 & 1 & 3 & 1223 & & & & & & & 7 & 6 & 11 & 7 & 14 & 11 & & & & & 56 \\
\hline 81414 & 4 & & 2 & 1236 & & & & & & & 18 & 10 & 8 & 8 & 3 & 5 & & & & & 52 \\
\hline 1434 & 4 & 1274 & 4 & 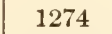 & .. & & & & & 2 & 10 & 10 & 5 & 9 & 7 & 5 & & . & & & 48 \\
\hline 1441 & 4 & 1301 & 3 & 1292 & $\cdots$ & & & & & & 11 & 16 & 11 & 6 & 10 & 9 & & & & & 63 \\
\hline 146 & 4 & 131 & 4 & 1317 & . . & & &. & & 1 & 9 & 15 & 11 & 4 & 4 & 2 & & .. & & & \\
\hline 146 & 3 & 1292 & 3 & & & & & & & & 5 & 2 & 4 & 5 & 3 & 4. & & 1 & & & 24 \\
\hline 14 & 4 & 1292 & 4 & 12 & 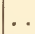 & & & .. & & & 6 & 1 & 2 & & 3 & 2 & & 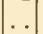 & & & 14 \\
\hline 1 & 4 & & 3 & & & & & 1 & & 1 & 19 & 16 & 5 & 3 & 4 & 3 & & & & & \\
\hline 1 & 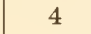 & & 3 & & 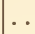 & & & & 1 & $\cdots$ & 14 & 4 & 9 & 6 & 6 & 2 & & . & & & 42 \\
\hline 1 & 3 & & 3 & & & & & & & . & 11 & 12 & 9 & 10 & 10 & 10 & & & & & \\
\hline 1 & 4 & & 3 & & 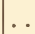 & & & & & . & 6 & 14 & 13 & 14 & 7 & 10 & i) & 1. & & & \\
\hline & 4 & & 3 & & & & & & & & 29 & 30 & 10 & 12 & 6 & 11 & & . & & & \\
\hline & 4 & & 3 & & & & & & & 2 & 20 & 22 & 13 & 8 & 5 & 11 & 1 &. & & & \\
\hline & 3 & & 3 & & & & & & & 1 & 37 & 61 & 9 & 7 & 2 & 4 & & . . & & & 121 \\
\hline & 4 & & 3 & & & & & & & 2 & 15 & 32 & 10 & 10 & 9 & 3 & & .. & & & 81 \\
\hline & 4 & & 3 & & & & & & & & 18 & 15 & 9 & 7 & 1 & 4 & &.. & & & 54 \\
\hline & 4 & & 3 & & & & & & & 2 & 40 & 39 & 12 & 14 & 1 & 2 & & & & & 110 \\
\hline & 4 & & 3 & & & & & & & & 2 & 9 & 3 & 3 & 1 & 2 & & . & & & 20 \\
\hline 1 & 4 & & : & & & & & & & 1 & 19 & 16 & 6 & 3 & 3 & 4 & & & & & 52 \\
\hline & 4 & & 3 & 1 & & & & 1 & & 3 & 62 & 37 & 17 & 5 & 7 & 4 & & . & . & & 136 \\
\hline & 4 & & 3 & & & & & & .. & 8 & 31 & 34 & 19 & 11 & 2 . & 1 & & . & & & 105 \\
\hline 1573 & 4 & 1433 & 3 & 1411 & $\cdots$ & ${ }^{\circ}$ & & 1 & & 12 & 44 & 28 & 13 & 13 & 5 & 2 & & . & & & 120 \\
\hline$F_{9} 1666$ & 4 & 1488 & 4 & 1488 & & & & & & 3 & 50 & 41 & 8 & 8 & 3 & 2 & & .. & & & 115 \\
\hline & 4 & & 3 & & & & & & & & 2 & 2 & 3 & 3 & 2 & 4 & & i & & & 17 \\
\hline & 4 & & & & & & & & & & 1 & 9 & 3 & 3 & 1 . & . & & & & & 17 \\
\hline & 4 & & 3 & & & & & & & 2 & 20 & 11 & 9 & 8 & 10 & 2 & i & & & & 63 \\
\hline & 4 & & 3 & & & & & & & 2 & 11 & 10 & 3 & 3 . & & & & & & & 29 \\
\hline & 4 & 1 & 3 & & .. & & & & & 1 & 5 & 6 & 1 & 5 & 1 & 1 & & & & & 20 \\
\hline & 4 & & $:$ & & & & & & & 5 & 18 & 11 & 8 & 5. & 3 & 1 & & & & & 51 \\
\hline & 1 & & 3 & & & & & & 1 & 6 & 29 & 20 & 3 & 1 & 2 & 2 & & & & & 64 \\
\hline 1779 & 3 & 15 & 3 & 573 & & & & & & & 6 & 6 & 7 & 5 . & & 1 & & & & & 25 \\
\hline$F_{10} 18$ & 4 & & 3 & & & & & & & 1 & 14 & 18 & 2 & 3 & 2 & & & & & & 40 \\
\hline 110 & & & & & & & & & & & 8 & 14 & 5 & 9 . & & 1 & & & & & 37 \\
\hline & 4 & & ? & & & & & 4 & & 2 & 14 & 11 & 1 . & & 2 & & & & & & 34 \\
\hline & 4 & & & & & & & 2 & & 3 & 17 & 3 & 5 & 1 & & 1 & & & & & 59 \\
\hline 18 & 4 & & 3 & & & & & & & 3 & 13 & 13 & 1 & 2 & 1 & & & & & & 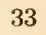 \\
\hline & 4 & & & & & & & & & & 10 & 11 & I & & & & & & & & 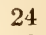 \\
\hline 1943 & 4 & $18 \mathrm{~s}$ & 4 & 1819 & & & & 1 & & 4 & 16 & 14 & 1 & 2. & & & & & & & 38 \\
\hline & 4 & & 2 & & & & & & & 3 & 27 & 38 & 4 & 2 & 2 & 1 & & & & & 77 \\
\hline 2 & 4 & & 3 & & & & & & & & 5. & & 3 & $\tilde{2}$. & & 2 & & & & & 12 \\
\hline & 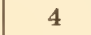 & & & & & & & 3 & & 8 & 35 & 20 & 8 & 3 . & & 1 & & & & & 78 \\
\hline & 4 & & 3 & & & & & & & & 10 & 4 & 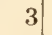 & 3 . & & & & & & & 20 \\
\hline 2110 & 4 & & 2 & 870 & & & & 5 & 2 & 2 & 21 & 20 & 2 & 5 & 1 & & & & & & 58 \\
\hline $\mathrm{F}_{12} 2189$ & 4 & & 3 & & & & & & & 4 & 28 & 33 & 12 & 10 & 1 & 6 & & & & & 94 \\
\hline 22 & 0 & & 3 & & & & & & 2 & 2 & 6 & 7 & 11 & 7 & 1 & 3 & & & & & 39 \\
\hline 2272 & 3 & 2110 & 2 & 2110 & & & & & & & 11 & 14 & 4 & 4 & 8 & 3 & & & & & 44 \\
\hline
\end{tabular}


TABle 32.-SPECK MiNes Iaxk.

\begin{tabular}{|c|c|c|c|c|c|c|c|c|c|c|c|c|c|c|c|c|c|c|}
\hline \multirow{3}{*}{$\begin{array}{c}\text { Genera- } \\
\text { tion and } \\
\text { culture } \\
\text { No. }\end{array}$} & \multicolumn{3}{|c|}{ Parents. } & \multicolumn{2}{|c|}{1} & 2 & \multicolumn{2}{|c|}{3} & \multicolumn{2}{|c|}{4} & \multicolumn{2}{|l|}{$\tilde{j}$} & \multicolumn{2}{|c|}{6} & \multicolumn{2}{|c|}{$i$} & A & \multirow{3}{*}{ (E) } \\
\hline & \multicolumn{2}{|c|}{ Grade. } & \multirow{2}{*}{ Culture. } & \multirow{2}{*}{9} & \multirow{2}{*}{$0^{7}$} & \multirow[b]{2}{*}{$\sigma^{7}$} & \multirow[b]{2}{*}{ q } & \multirow[b]{2}{*}{$\sigma^{7}$} & \multirow[b]{2}{*}{ \% } & \multirow[b]{2}{*}{$\sigma^{7}$} & \multirow[b]{2}{*}{ ? } & \multirow[b]{2}{*}{$\sigma^{7}$} & \multirow[b]{2}{*}{ \& } & \multirow[b]{2}{*}{$\sigma^{\prime \prime}$} & \multirow[b]{2}{*}{ P $c$} & \multirow[b]{2}{*}{8} & \multirow[b]{2}{*}{$8=$} & \\
\hline & \% & $0^{7}$ & & & & & & & & & & & & & & & & \\
\hline$F_{1} 1331\{$ & $\begin{array}{l}4 \\
\cdots\end{array}$ & Not-D & $\left\{\begin{array}{c}1168 \\
\text { Inbred speck }\end{array}\right\}$ & & & & & 4 & 39 & 34 & 17 & 17 & $\lambda$ & 6. & & & & 125 \\
\hline $\begin{array}{r}F_{2} 1465 \\
1487 \\
1507\end{array}$ & $\begin{array}{l}4 \\
4 \\
4\end{array}$ & $\begin{array}{l}4 \\
4 \\
3\end{array}$ & & & & & 1 & & $\begin{array}{l}22 \\
25 \\
36\end{array}$ & $\begin{array}{l}18 \\
15 \\
31\end{array}$ & $\begin{array}{l}10 \\
12 \\
21\end{array}$ & $\begin{array}{l}12 \\
14 \\
20\end{array}$ & $\begin{array}{r}11 \\
10 \\
8\end{array}$ & $\begin{array}{r}6 \\
15 \\
7\end{array}$ & & 1 & & $\begin{array}{r}79 \\
95 \\
124\end{array}$ \\
\hline $\begin{array}{r}F_{3} 1594 \\
1595 \\
1617 \\
1640 \\
1728\end{array}$ & $\begin{array}{l}4 \\
6 \\
4 \\
4 \\
4\end{array}$ & $\begin{array}{l}4 \\
4 \\
4 \\
4 \\
4 \\
4\end{array}$ & & . & & 2 & 1 & $\begin{array}{r}11 \\
4 \\
2 \\
2 \\
\cdots\end{array}$ & \begin{tabular}{l|}
56 \\
21 \\
30 \\
30 \\
19
\end{tabular} & \begin{tabular}{l|}
51 \\
23 \\
19 \\
29 \\
17
\end{tabular} & \begin{tabular}{r|}
4 \\
7 \\
3 \\
10 \\
11
\end{tabular} & $\begin{array}{r}2 \\
4 \\
1 \\
10 \\
6\end{array}$ & $\begin{array}{l}0 \\
1 \\
2 \\
1 \\
6 \\
5\end{array}$ & $\begin{array}{r}1 \\
2 \\
3 \\
1 \\
1\end{array}$ & & & & $\begin{array}{r}124 \\
83.3 \\
56 \\
89 \\
59\end{array}$ \\
\hline $\begin{array}{r}F_{4} 1766 \\
1784 \\
1786 \\
1820 \\
1841 \\
1861\end{array}$ & $\begin{array}{l}4 \\
4 \\
4 \\
4 \\
4 \\
4\end{array}$ & $\begin{array}{l}4 \\
3\end{array}$ & & & & & $\cdots$ & \begin{tabular}{|r|}
6 \\
1 \\
1 \\
6 \\
- \\
2
\end{tabular} & $\begin{array}{l}45 \\
12 \\
11 \\
37 \\
24 \\
24\end{array}$ & $\begin{array}{l}48 \\
10 \\
13 \\
30 \\
23 \\
23\end{array}$ & \begin{tabular}{r|}
4 \\
$\cdots$ \\
1 \\
4 \\
7 \\
12
\end{tabular} & $\begin{array}{r}3 \\
3 \\
\cdots \\
2 \\
7 \\
10\end{array}$ & $\begin{array}{l}2 \\
1\end{array}$ & 1 & & & & $\begin{array}{r}109 \\
26\end{array}$ \\
\hline $\begin{array}{r}F_{5} 1906 \\
1907^{1} \\
1996^{1} \\
1955 \\
1978 \\
1986 \\
2009\end{array}$ & $\begin{array}{l}4 \\
4 \\
4 \\
4 \\
4 \\
4 \\
4\end{array}$ & $\begin{array}{l}4 \\
3\end{array}$ & & & & 1 & $\cdots$ & $\begin{array}{r}4 \\
1 \\
4 \\
- \\
3 \\
1\end{array}$ & $\begin{array}{r}22 \\
14 \\
27 \\
24 \\
22 \\
9 \\
14\end{array}$ & $\begin{array}{l}23 \\
23 \\
25 \\
13 \\
16 \\
11 \\
15\end{array}$ & $\begin{array}{r}1 \\
\cdots \\
2 \\
3 \\
7 \\
2 \\
1\end{array}$ & $\begin{array}{r}1 \\
2 \\
3 \\
5 \\
4 \\
2 \\
\ldots\end{array}$ & $i$ & 1 & & & & $\begin{array}{l}27 \\
31\end{array}$ \\
\hline $\begin{array}{r}\mathrm{F}_{6} 2088 \\
2093 \\
2111 \\
2127\end{array}$ & $\begin{array}{l}4 \\
4 \\
4 \\
4\end{array}$ & 4 & & & & $\begin{array}{l}1 \\
\cdots\end{array}$ & $\begin{array}{c}\cdots \\
\cdots \\
1\end{array}$ & $\begin{array}{r}5 \\
3 \\
5 \\
1\end{array}$ & $\begin{array}{l}34 \\
11 \\
24 \\
11\end{array}$ & \begin{tabular}{l|}
24 \\
14 \\
15 \\
13
\end{tabular} & $\begin{array}{l}1 \\
1 \\
1 \\
4\end{array}$ & $\begin{array}{l}\cdots \\
\cdots \\
1 \\
1\end{array}$ & 1 & & & & & $\begin{array}{l}65 \\
26 \\
47 \\
31\end{array}$ \\
\hline $\begin{array}{r}F_{7} 2182 \\
2196 \\
2233\end{array}$ & $\begin{array}{l}4 \\
4 \\
4\end{array}$ & 3 & & & & 1 & & $\begin{array}{r}1 \\
10\end{array}$ & $\begin{array}{r}18 \\
9 \\
49\end{array}$ & $\begin{array}{r}20 \\
4 \\
43\end{array}$ &  & $\begin{array}{l}1 \\
3 \\
3\end{array}$ & & & & & & $\begin{array}{r}39 \\
14 \\
106\end{array}$ \\
\hline $\mathrm{F}_{8} 2348$ & 4 & 2 & & & & & & & 8 & 11 & 3 & 4 & & 1 & & & & 27 \\
\hline & & & & & & & & & & & & & & & & & & \\
\hline 2414 & & Mass. & $\begin{array}{l}\text { About } \mathrm{F}_{2} \\
\text { from } 234 \mathrm{~S}\end{array}$ & & 1 & 1 & & 1 & 18 & 15 & 5 & 2 & 1 & & & & & 44 \\
\hline $\begin{array}{rl}F_{1} & 2431 \\
& 2432\end{array}$ & $\begin{array}{l}4 \\
4\end{array}$ & $\begin{array}{l}4 \\
1\end{array}$ & & & & & & $\begin{array}{l}1 \\
2\end{array}$ & $\begin{array}{l}3 \\
7\end{array}$ & $\begin{array}{l}2 \\
3\end{array}$ & $\begin{array}{l}1 \\
1\end{array}$ & i & & & & & & 14 \\
\hline$F_{2} 2486$ & 4 & 4 & 2431 & & & & & 1 & 5 & 16 & 7 & 5 & 2 & & & & & 30 \\
\hline $\begin{array}{rl}\mathrm{F}_{3} & 2545 \\
2546\end{array}$ & 4 & $\begin{array}{l}4 \\
4\end{array}$ & & & & & & \begin{tabular}{l|}
1 \\
2
\end{tabular} & $\begin{array}{r}10 \\
9\end{array}$ & $\begin{array}{l}16 \\
11\end{array}$. & 3 . & & 1 & 1 & & & & $\begin{array}{l}32 \\
22\end{array}$ \\
\hline $\begin{array}{l}2549 \\
2572\end{array}$ & 4 & & & & - & & & 6 & 14 & 9 & 2 & 1 & 1 & 1 & & & & 3.4 \\
\hline 2 & 4 & 3 & & & & 1 & & $\begin{array}{l}2 \\
6\end{array}$ & $\begin{array}{r}3 \\
20\end{array}$ & $\begin{array}{r}2 \\
22\end{array}$ & $\begin{array}{l}3 \\
4\end{array}$ & $\ldots$ & 1 & & & & & 11 \\
\hline 2 & 4 & 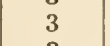 & & & & & & 2 & 17 & 9 & 3 & 2 & & 1 & & & & $3 t$ \\
\hline 2 & $A$ & 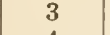 & & & & 1 & & 1 & 7 & 10 & 1 & 1 & & & & & & 21 \\
\hline 2 & 4 & 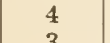 & & & & & & & 10 & 5 & 2 & 1 & & & & & & $\begin{array}{l}1.5 \\
37\end{array}$ \\
\hline $\mathrm{F}_{5}$ & 4 & 3 & 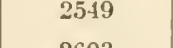 & & & 3 & 4 & 3 & 17 & 8 & 2 & & & & & & & 3. \\
\hline $\mathrm{F}_{6}$ & 4 & 2 & 2603 & & & 2 & 1 & 6 & 2 & 3 & 1 & & & & & & & 10 \\
\hline $\mathrm{F}_{7} 2860$ & 4 & 4 & 2760 & & & & & & 5 & 1 & 1 & & & & & & & ' \\
\hline
\end{tabular}

1First and seeond broods from same pair.

${ }^{2}$ Two males and two females; the same flies as the parents of 2445 and $2 \$ 6$. 
Table 33.-Cross of Inbred Plus lines.

\begin{tabular}{|c|c|c|c|c|c|c|c|c|c|c|c|c|c|c|c|c|c|c|c|c|}
\hline \multirow{3}{*}{$\begin{array}{c}\text { Genera- } \\
\text { tion and } \\
\text { culture } \\
\text { No. }\end{array}$} & \multicolumn{3}{|c|}{ Parents. } & \multirow{2}{*}{\multicolumn{2}{|c|}{1}} & \multirow{2}{*}{2} & & \multirow{2}{*}{\multicolumn{2}{|c|}{3}} & \multirow{2}{*}{\multicolumn{2}{|c|}{4}} & \multirow{2}{*}{\multicolumn{2}{|c|}{5}} & \multirow{2}{*}{\multicolumn{2}{|c|}{6}} & \multirow{2}{*}{\multicolumn{2}{|c|}{7}} & \multirow{2}{*}{\multicolumn{2}{|c|}{8}} & \multirow{3}{*}{ 皆 } \\
\hline & \multicolumn{2}{|c|}{ Grade. } & \multirow{2}{*}{$\begin{array}{l}\text { Cul- } \\
\text { ture. }\end{array}$} & & & & & & & & & & & & & & & & & \\
\hline & ㅇ & $\sigma^{7}$ & & q & $\sigma^{7}$ & \% & & 운 & $\sigma^{7}$ & \% & $\sigma^{x}$ & ㅇ & $0^{7}$ & 9 & $0^{\pi}$ & 웅 & $0^{7}$ & \% & $\sigma^{x}$ & \\
\hline $\mathrm{F}_{1} 1941$ & 5 & 5 & $\begin{array}{l}1763 \\
1788\end{array}$ & & & & & & 2 & 1 & & 9 & 4 & 8 & 18 & & & & & 42 \\
\hline $\mathrm{F}_{2} 2053$ & & 6 & 1941 & & & . & & & & & & 2 & 3 & 12 & 7. & & & & 1 & 25 \\
\hline 2054 & Not-D & 6 & 1941 & 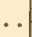 & & . & & . & 3 & 21 & 3 & 16 & 6 & 22 & 6 & & & & .. & 77 \\
\hline 2082 & 6 & 5 & 1941 & 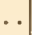 & & . & & . & $\ldots$ & 1 & I & 10 & 4 & 10 & 8 & & & $\cdots$ & $\ldots$ & 33 \\
\hline 2083 & 6 & 6 & 1941 &  & & . & & & $\ldots$ & 3 & 2 & 5 & 7 & 5 & 6 & $\ldots$ & 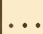 & . & $\ldots$ & 28 \\
\hline 2104 & 6 & 6 & 1941 & . & & . . & & . & 3 & 11 & 9 & 14 & 10 & 20 & 14 & . & .. & . . & $\ldots$ & 81 \\
\hline 2122 & 5 & 6 & 1941 & . & & & & & . & 1 & 2 & 7 & 8 & 13 & 4 & & & & & 35 \\
\hline
\end{tabular}

PLUS SELECTED SERIES.

\begin{tabular}{|c|c|c|c|c|c|c|c|c|c|c|c|c|c|c|c|c|c|c|c|c|}
\hline $\mathrm{F}_{3} 2160$ & 6 & 8 & 2053 & & & & & & & 1 & & & 4 & 9 & 16 & & & 2 & & 32 \\
\hline 2161 & 6 & 6 & 2053 & & & & 1 & & & & & & 2 & 6 & 7 & 2 & 2 & . & & 20 \\
\hline 2162 & 6 & 6 & 2053 & & & & $\cdots$ & & 2 & 4 & 2 & 15 & 11 & 21 & 24 & & & . & & 79 \\
\hline 2164 & 6 & 0 & 2054 & & & & - & . . & 1 & 4 & 1 & 8 & 7 & 32 & 21 & 1 & & & & 76 \\
\hline 2177 & 6 & 6 & 2053 & & & & & $\ldots$ & & $\ldots$ & $\ldots$ & 2 & & 23 & 16 & & . & 1 & 1 & 43 \\
\hline 2185 & 6 & 6 & 2083 & & & & & & & $\ldots$ & $\ldots$ & 6 & 2 & 14 & 19 & 3 & & & $\ldots$ & 44 \\
\hline 2229 & 6 & 6 & 2104 & & & & & & & $\ldots$ & & & & 3 & 12 & 2 & 1 & . & $\ldots$ & 18 \\
\hline 2249 & 6 & 6 & 2122 & & & & . & & & ... & 3 & 7 & 6 & 20 & 25 & 1 & $\ldots$ & & $\ldots$ & 62 \\
\hline $\mathrm{F}_{4} 2280$ & 6 & 6 & 2177 & & & & & & & . & . & . & 1 & 8 & 15 & 2 & 2 & & . & 28 \\
\hline 2282 & 6 & 6 & 2160 & & & & & & & & & & & 3 & 6 & 1 . & & & & 10 \\
\hline 2287 & 6 & 6 & 2162 & & & &  & & & • & & 2 & . & 21 & 17 & & . . & & . & 40 \\
\hline 2298 & 0 & 6 & 2160 & & & & & & & $\ldots$ & .. & .. & 3 & 15 & 13 & 7 & 1 . & 1 & 10 & 40 \\
\hline 2301 & 7 & 6 & 2185 & & & & & & & $\ldots$ & & .. & 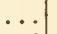 & 7 & 11 & & & & $\ldots$ & 18 \\
\hline 2314 & 6 & 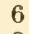 & 2164 & & & & & & & $\cdots$ & . & 1 & 1 & 7 & 6 & 2 & 1 & & & 18 \\
\hline 2317 & 6 & 8 & 2177 & & & & $\because$ & & . & 2 & . & 1 & 1 & 19 & 16 & 2 & 3 & & & 4 \\
\hline 2332 & 7 & 6 & 2229 & & & & & & & $\ldots$ & . & .. & .. & 21 & 14 & 9 & 10 & 1 & 2 & 57 \\
\hline 2355 & 7 & 6 & 2249 & & & & & & & & & & & 4 & 7 & 1 & & & & 15 \\
\hline
\end{tabular}

MINUS SELECTED SERIES.

\begin{tabular}{|c|c|c|c|c|c|c|c|c|c|c|c|c|c|c|c|c|c|c|c|c|}
\hline $\mathrm{F}_{3} 2178$ & 4 & 5 & 2054 & & & & & & & 2 & 1 & 2 & 4 & 18 & 22 & 2 & & & & \\
\hline $\begin{array}{l}2197 \\
-3\end{array}$ & 5 & 5 & 2053 & & & & & & &. & & 1 & 1 . & 6 & 8 & 3 & $i$ & & & 20 \\
\hline 2198 & 4 & 5 & 2054 & & & & & & & ... & & & & 6 & 3 & 2 & 2 & & & 13 \\
\hline 2212 & 4 & 5 & 2083 & & & & & & & 1) & & 3. & 1 & 12 & 13. &  & 1 & & . & 31 \\
\hline 225 & 4 & 4 & 2 & & & & & & & 4 & 3 & 4 & 14 & 17 & 27 . & & & & & 69 \\
\hline 2 & 4 & 3 & 2 & & & & & & & & & & $\ldots$ & 9 & 11 . & . & 1 & & . & 21 \\
\hline 2 & 4 & 4 & 3 & & & & & & & ... & 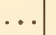 & 1 & 2 & 7 & 4 . & 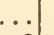 & 1 & & & 15 \\
\hline 2271 & 4 & 3 & 2104 & & & & & & & .. & & . & $\ldots$ & 4 & 4 & 2 . & - & & 1 & 11 \\
\hline $\mathrm{F}_{4} 2329$ & 5 & 5 & 2212 & & & & & & & & 1 & 1 & 1 & 6 & 6 . & ... & 1 & & . & 16 \\
\hline 2385 & 4 & 5 & 0 & & & & & & & 1 & & & $\cdots$ & 8 & 7 . & .. & 1 & & $\ldots$ & 17 \\
\hline$F_{1} 2069\{$ & 5 & 6 & $\begin{array}{l}1944 \\
1939\end{array}$ & & & & & & 2 & 9 & 8 & 12 & 12 & 15 & 8 & 1 & 1 & & & 68 \\
\hline $\mathrm{F}_{2} 2172$ & 5 & 5 & 2069 & & & & & & & 4 & 7 & 17 & 14 & 43 & 37 & 1 & 1 & & & 124 \\
\hline 217 & 7 & 7 & 2 & & & & & & 1 & 2 & 5 & 17 & 15 & 37 & 33 & 1 & $\because$ & & & 111 \\
\hline 2244 & 4 & 4 & 2069 & & & & & & $\cdots$ & 3 & 5 & 8 & 13 & 27 & 17. & .. & .. & & ... & 73 \\
\hline $\mathrm{F}_{3} 2279$ & 7 & 6 & 217 & & & & & & & & & & 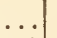 & 17 & 20 & 3 & 1 & 2 & .. & 43 \\
\hline 228 & 5 & 4 & 2 & & & & & & & & 4 & 3 & 5 & 37 & 39 & 4 & 4 & & & 96 \\
\hline 22 & 6 & 6 & 2 & & & & & & & . & 2 & 2 & 2 & 39 & 36 & 5 & & & & 88 \\
\hline 233 & 4 & 4 & 2172 & & & & & & & & & .. & 1 & 23 & 20 & 3 & 9 & & & 58 \\
\hline & 4 & 4 & & & & & & & 1 & 6 & 6 & 16 & 12 & 29 & 41 & 3 & 1 & & & 115 \\
\hline 2403 & 4 & 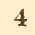 & 2244 & & & & & & & 1 & .. & 3 & 2 & 14 & 13 & & 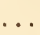 & & ... & 33 \\
\hline $\mathrm{F}_{4} 2409$ & 7 & 7 & 2279 & & & & & & $\ldots$ & . & 1 & 1 & $\ldots$ & 12 & 4 & & 2 & 1 & ... & 21 \\
\hline$F_{1} 1602\{$ & 6 & 6 & 1422 & & & & & & 1 & & 8 & 7 & 13 & 28 & 25 & & $\ldots$ & & & 82 \\
\hline $\mathrm{F}_{2} 1751$ & 6 & $\begin{array}{l}0 \\
6\end{array}$ & & & & & 1 & & 5 & 5 & 7 & 6 & 11 & 6 & 3 & & & & $\ldots$ & 44 \\
\hline & 6 & 6 & & & & & & & 1 & 1 & 4 & 4 & 3 & 8 & 6 & & . . & & $\ldots$ & 27 \\
\hline 1791 & 6 & 6 & 1602 & & & & & & & & & 1 & 2 & 9 & 17 & 1 & 1 & & & 31 \\
\hline
\end{tabular}


AN ANALYSIS OF THE EFFECT OF SELECTION.

Table 34.-Cross, Plus line $\times$ Mines Linf.

\begin{tabular}{|c|c|c|c|c|c|c|c|c|c|c|c|c|c|c|c|c|c|c|c|c|}
\hline \multirow{3}{*}{$\begin{array}{c}\text { Genera- } \\
\text { tion and } \\
\text { culture } \\
\text { No. }\end{array}$} & \multicolumn{3}{|c|}{ Parents. } & \multirow{2}{*}{\multicolumn{2}{|c|}{1}} & \multirow{2}{*}{\multicolumn{2}{|c|}{2}} & \multirow{2}{*}{\multicolumn{2}{|c|}{3}} & \multirow{2}{*}{\multicolumn{2}{|c|}{4}} & \multirow{2}{*}{\multicolumn{2}{|c|}{5}} & \multirow{2}{*}{\multicolumn{2}{|c|}{ B }} & \multirow{2}{*}{\multicolumn{2}{|c|}{7}} & \multirow{2}{*}{\multicolumn{2}{|c|}{8}} & \multirow{3}{*}{$\stackrel{3}{\circ}$} \\
\hline & \multicolumn{2}{|c|}{ Grade. } & \multirow{2}{*}{$\begin{array}{l}\text { Cul- } \\
\text { ture }\end{array}$} & & & & & & & & & & & & & & & & & \\
\hline & 우 & $0^{7}$ & & \% & $\sigma^{7}$ & १ & $0^{\prime}$ & $\%$ & $0^{x}$ & 9 & $\sigma^{7}$ & ? & $0^{7}$ & ? & $0^{7}$ & 8 & $\sigma^{7}$ & 9 & $\sigma^{7}$ & \\
\hline$F_{1} 2939$ & & 4 & $\left.\begin{array}{l}2866 \\
2860\end{array}\right\}$ & $\cdots$ & 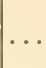 & $\cdots$ & 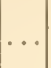 & & & 1 & & 4 & 9 & 13 & 15 & 1 & & & & 43 \\
\hline 2950 & 4 & 6 & $\left.\begin{array}{l}2860 \\
2866\end{array}\right\}$ & & & & 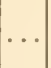 & & & & & & 3 & 2 & 5. & & & & & 10 \\
\hline$F_{2} 2999$ & 6 & 6 & 2939 & & & & & & 5 & 5 & 8 & 15 & 14 & 19 & 9 & 1 & & & & 70 \\
\hline 3004 & 5 & 5 & 2939 & & & & 3 & 2 & 10 & 26 & 16 & 12 & 16 & 6 & 6 & & & & & 107 \\
\hline 3008 & 4 & 6 & 2939 & 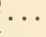 & & & 8 & 1 & 14 & 31 & 26 & 28 & 21 & 37 & 19 & & & & & 185 \\
\hline$F_{3} 3062$ & 6 & 6 & 3008 & . & & & & & & 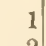 & & 2 & 1 & 28 & 29 & 5 & 4 & & & 70 \\
\hline 3063 & 3 & 2 & 3004 & & & & . & 1 & 2 & 2 & 2 & 6 & 12 & 28 & 15 & & & & & 68 \\
\hline 3064 & 4 & 3 & 3004 & $\ldots$ & & & & & $\cdots$ & 15 & 14 & 19 & 15 & 15 & 8 & & . & & $\cdots$ & 80 \\
\hline $\begin{array}{l}3116 \\
3065\end{array}$ & 4 & 3 & 3004 & & & . & & . & 2 & 14 & 12 & 19 & 13 & 11 & 12. & & 1 & & & 84 \\
\hline 3065 & 5 & 5 & 3004 & & & & & . & $\cdots$ & $\cdots$ & 2 & 5 & 2 & 23 & 27 & 2 & & & .. & 61 \\
\hline 3066 & 6 & 6 & 3004 & . & & $\because$ &. & . & .. & 3 & 1 & 4 & 5 & 23 & 20 & 1 & 2 & & & 59 \\
\hline 3118 & 6 & 6 & 3004 & & & & & . & 2 &. & 2 & 3 & 3 & 13 & 1 . & & & & & 24 \\
\hline 3077 & 4 & 2 & 3004 & . & & $\cdots$ & & . & $\ldots$ & & .. & 1 & 3 & 16 & 25 & 4 & 3 & 2 & 1 & 55 \\
\hline 3078 & 6 & 6 & 3008 & $\cdots$ & & 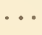 & & . & ... & & 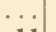 & 5 & 4 & 26 & 35 & 1 & 3 & & & 74 \\
\hline 3079 & 4 & 3 & 3008 & & & & & & . & 9 & 11 & 11 & 20 & 35 & 33 & 1 & 1 & & & 121 \\
\hline 3088 & 6 & 6 & 3004 & 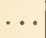 & & . & & & & & 1 & 4 & 1 & 24 & 17 & 1 & $\ldots$ & & & 48 \\
\hline 3089 & 3 & 2 & 3008 & & & & & & & 14 & 11 & 12 & 16 & 9 & 11 & & 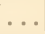 & & & 73 \\
\hline 3090 & 6 & 6 & 3008 & $\cdots$ & & & & & & 3 & 9 & 5 & 10 & 29 & 23 & 1 & 1 & & & 81 \\
\hline 3096 & 5 & 5 & 3008 & 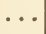 & & & & • & $\cdots$ & 6 & 11 & 10 & 12 & 24 & 8 & & $\ldots$ & & & 71 \\
\hline 3111 & 6 & 6 & 3008 & $\cdots$ & & & & & $\ldots$ & 2 & 2 & 4 & 13 & 14 & 3 . & & . & $\cdots$ & & 38 \\
\hline 3112 & 5 & 5 & 3008 & & & & & & & 2 & $\cdots$ & 7 & 10 & 51 & 40 & & & & & 110 \\
\hline
\end{tabular}

Table 35.-Reversed Selection, Minus to Plus.

\begin{tabular}{|c|c|c|c|c|c|c|c|c|c|c|c|c|c|c|c|c|}
\hline \multirow{3}{*}{$\begin{array}{c}\text { Genera- } \\
\text { tion and } \\
\text { culture } \\
\text { No. }\end{array}$} & \multirow{3}{*}{$\begin{array}{c}\text { Inbred } \\
\text { gens. } \\
\text { before } \\
\text { reversal. }\end{array}$} & \multicolumn{3}{|c|}{ Parents. } & \multirow{2}{*}{1} & & & & & & \multirow{2}{*}{7} & \multirow{2}{*}{8} & \multirow{3}{*}{ క్ } \\
\hline & & \multicolumn{2}{|c|}{ Grade. } & \multirow{2}{*}{$\begin{array}{l}\text { Cul- } \\
\text { ture. }\end{array}$} & & & & & & & & & & & & \\
\hline & & 운 & $\sigma^{\pi}$ & & $|\%| \sigma^{\prime} \mid$ & \&|ন| & $\%$ & \multicolumn{2}{|c|}{$\%\left|0^{x}\right|$} & \multicolumn{2}{|c|}{$\%$} & \multicolumn{2}{|c|}{$9 \mid 0^{x}$} & $9\left|0^{2}\right|$ & $8 \mid \sigma^{2}$ & \\
\hline \multicolumn{17}{|c|}{ 900. Inbred Minus Line. } \\
\hline $\mathrm{F}_{3} 1$ & 2 & 6 & 6 & 1007 & & & & 10 & 13 & 16 & 13 & 11 & 5 & & & 68 \\
\hline $\mathrm{F}_{4} 1175$ & $\ldots$ & 6 & 6 & 1086 & & & & 2 & 7 & 8 & 14 & 26 & 13 & 1 & & 71 \\
\hline$F_{5} 12$ & $\ldots$ & 6 & 6 & 11 & & & & 11 & 4 & 13 & 14 & 8 & 5 & 1 & & 56 \\
\hline & & 6 & 6 & 1175 & & & & 7 & 5 & 6 & 4 & 12 & 7 & 1 . & & $\therefore$ \\
\hline
\end{tabular}

868. Inbred Minus Line.

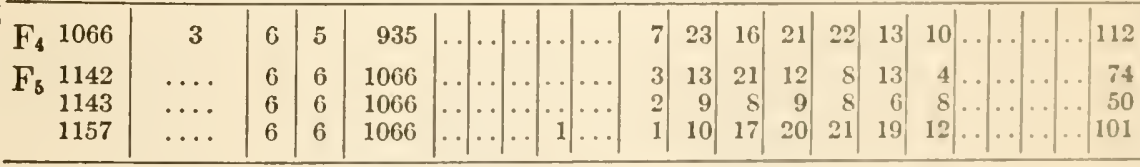

Speck Minus Line.

\begin{tabular}{|c|c|c|c|c|c|c|c|c|c|c|c|c|c|c|c|}
\hline $\mathrm{F}_{3} 1627$ & 2 & 6 & 6 & 1507 & 1. & & & & 60 & $48 \mid$ & 25 & 12 & 9 & $\pi$ & 161 \\
\hline$F_{4} \begin{array}{l}1783 \\
1843\end{array}$ & $\ldots$ & $\begin{array}{l}6 \\
6\end{array}$ & $\begin{array}{l}6 \\
6\end{array}$ & $\begin{array}{l}1627 \\
1627\end{array}$ & $\cdots$ & & $\ldots$ & $\begin{array}{l}1 \\
3\end{array}$ & $\begin{array}{r}8 \\
16\end{array}$ & $\begin{array}{l}11 \\
17\end{array}$ & $\hat{2}$ & $\begin{array}{r}10 \\
4\end{array}$ & 4 & $\begin{array}{l}4 \\
2\end{array}$ & $\begin{array}{l}40 \\
51\end{array}$ \\
\hline$F_{5} 1893$ & .... & 6 & 6 & 1783 & . & 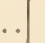 & $1 .$. & 1 & 4 & 10 & 3 & 1 & & 1 . & 21 \\
\hline
\end{tabular}

Cultures in brackets are first and second broods from same pair. 
864. Inbred Line.

\begin{tabular}{|c|c|c|c|c|c|c|c|c|c|c|c|c|c|c|c|c|c|c|}
\hline \multirow{3}{*}{$\begin{array}{c}\text { Genera- } \\
\text { tion and } \\
\text { culture } \\
\text { No. }\end{array}$} & \multirow{3}{*}{$\begin{array}{c}\text { Inbred } \\
\text { gens. } \\
\text { before } \\
\text { rev ersal. }\end{array}$} & \multicolumn{3}{|c|}{ Parents. } & \multirow{2}{*}{1} & \multirow{2}{*}{\multicolumn{2}{|c|}{2}} & \multirow{2}{*}{\multicolumn{2}{|c|}{3}} & \multirow{2}{*}{\multicolumn{2}{|c|}{4}} & \multirow{2}{*}{\multicolumn{2}{|c|}{5}} & \multirow{2}{*}{\multicolumn{2}{|c|}{6}} & \multirow{2}{*}{7} & \multirow{2}{*}{8} & \multirow{3}{*}{ 吾 } \\
\hline & & \multicolumn{2}{|c|}{ Grade. } & \multirow{2}{*}{$\begin{array}{l}\text { Cul- } \\
\text { ture. }\end{array}$} & & & & & & & & & & & & & & \\
\hline & & 9 & $0^{\pi}$ & & $90^{\circ}$ & 9 & 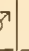 & $q$ & 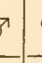 & ㅇ & 3 & \% & $r^{r}$ & & $90^{7}$ & $90^{2}$ & \\
\hline$F_{11} 1940$ & 10 & 4 & 5 & 1763 & . & & . & . & 1 & 6 & 2 & 6 & 4 & 10 & 3 & 1 . & & 33 \\
\hline $\mathrm{F}_{12} 2089$ & $\ldots$ & 4 & 5 & 1940 & & & & & & 1 . & & & 3 & 10 & 5 & 1 . & . & 20 \\
\hline 2125 & ... & 4 & 3 & 1940 & . & & 1 . & . & 1 & 3 & 3 & 6 & 4 & 4 & 7. & ... & & 29 \\
\hline $\mathrm{F}_{13} 2269$ & $\cdots$ & 4 & 4 & 2125 & & & & & 1 & 2 . & & 12 & 5 & 22 & 18 & \begin{tabular}{l|l|}
2 & 1
\end{tabular} & . & 62 \\
\hline \multicolumn{19}{|c|}{ 1002. Inbred Line. } \\
\hline$F_{5} 1522$ & 4 & 4 & 2 & 1375 & & & & & & 5 & 4 & 8 & 13 & 9 & 22 & 1 & & 62 \\
\hline$F_{6} 1686$ & ... & 4 & 4 & 1522 & & & . & & 2 & 10 & 13 & 5 & 5 & 4 & 7 . & & & 46 \\
\hline$F_{7} 1816$ & $\ldots$ & 4 & 4 & 1686 & & & 1 . & & 7 & 29 & 17 & 5 & 4. & 4 & 1 & & & 68 \\
\hline $\mathrm{F}_{8} 1958$ & $\cdots$ & 4 & 3 & 1816 & & & . & & * & 7 & 4 & 4 & 4 & 1 & 2 & 1 & & 23 \\
\hline $\mathrm{F}_{7} 190 \mathrm{~s}^{1}$ & 6 & 4 & 3 & 1734 & & & 1 . & & & 1 & 2 . &. & 1 & 2 & 5 & & & 12 \\
\hline $1997^{1}$ & 6 & 4 & 3 & 1734 & $\cdots$ & & 1 & 1 & 4 & 5 & 3 & 3 & 8 & 5 & 7 & & 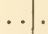 & 37 \\
\hline 1909 & 6 & 4 & 3 & 1734 & & & • & . & 5 & $17 \mid$ & 18 & 13 & 10 & 7 & 6 & & & 76 \\
\hline $\begin{array}{c}\text { New } \\
\mathrm{F}_{4} 2571\end{array}$ & $16 \pm$ & 5 & 5 & 2517 & & & & $\cdot$ & & & 1 & 1. & 4. & 19 & 22 & 2 & & 49 \\
\hline$F_{5} 2637$ & $\cdots$ & 6 & 5 & 2571 & & & & & . & & & $\cdots$ & & 4 & 9 & & & 13 \\
\hline $\begin{array}{c}\text { New } \\
F, 2583\end{array}$ & $16 \pm$ & 5 & 4 & 254 & & & & & & & 2 & 6 & & & & 1 & & 73 \\
\hline $\begin{array}{r}\Gamma_{4} \\
2629\end{array}$ & $16 \pm$ & 3 & 5 & 2547 & & & & & & & & 1 & 6 & 11 & $\begin{array}{r}24 \\
8\end{array}$ & 1 & & 26 \\
\hline
\end{tabular}

${ }^{1}$ Two broods from the same parents.

Table 37.-Tests for Modifying Factors. ${ }^{1}$

900. Inbred Minus Line.

\begin{tabular}{|c|c|c|c|c|c|c|c|c|c|c|c|c|c|c|c|c|c|c|}
\hline \multirow{2}{*}{$\begin{array}{c}\text { Genera- } \\
\text { tion and } \\
\text { culture } \\
\text { No. }\end{array}$} & \multicolumn{3}{|c|}{ Parents. } & \multirow{2}{*}{$\begin{array}{l}\text { Offspring } \\
\text { characters. }\end{array}$} & \multicolumn{2}{|c|}{1} & \multicolumn{2}{|c|}{2} & 3 & \multicolumn{3}{|c|}{4} & \multicolumn{2}{|c|}{5} & \multicolumn{2}{|c|}{6} & $\tau$ & \multirow{2}{*}{ 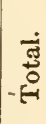 } \\
\hline & Soma. & Stock. & Culture. & & 우 & $\sigma^{7}$ & १. & $\sigma^{7}$ & o & & ? & $\sigma^{7}$ & 웅 & $\sigma^{x}$ & 웅 & $0^{7}$ & $910^{8}$ & \\
\hline 1737 & $\begin{array}{r}4 \\
\text { Sp }\end{array}$ & $\begin{array}{l}900 \\
\text { Sp }\end{array}$ & 1566 & & & & & & & & 12 & 11 & 7 & 6 & 5 & 12 & 1 & 56 \\
\hline \multirow[t]{2}{*}{1937} & $\begin{array}{r}\mathrm{Sp} \\
4\end{array}$ & $\mathrm{Sp}$ & 1737 & $\left\{\begin{array}{l}\text { Not- } \\
\text { - }\end{array}\right.$ & & & & & & & 1 & $\begin{array}{r}8 \\
10\end{array}$ & 10 & 6 & 5 & 4 . & & 35 \\
\hline & $\mathrm{Sp}$ & Sp & 1808 & Sot-sp. & & & . & & & & 5 & 20 & 6 & 5 & 4 & $\begin{array}{l}1 . \\
1 .\end{array}$ & & $\begin{array}{l}20 \\
41\end{array}$ \\
\hline 1970 & & $\cdots$ & 1737 & Spp. & & & & & & & 9 & 8 & 2 & 5 & 1 . & & & 26 \\
\hline \multicolumn{19}{|c|}{ 864. Inbred Plus Line. } \\
\hline \multirow{2}{*}{1921} & Sp & $\mathrm{Sp}$ & & & & & & & & & & & & & & & & \\
\hline & 6 & 864 & 1763 & & & & & & & & 3 & 2 & 3. & 11 & 15 & 10 . & & 45 \\
\hline \multirow[t]{2}{*}{2023} & Sp & $\mathrm{Sp}$ & & $\left\{\begin{array}{l}\text { Not-sp... } \\
\text { Sot }\end{array}\right.$ & & & & & & & 8 & 1 & 7 & 6 & 6 & 3 . & & 35 \\
\hline & 6 & $\sigma_{-}$ & 1921 & Sp. & & & & & & & 6 & 14 & 1 & 2 & 1 & 2 & & 26 \\
\hline \multirow[t]{2}{*}{2024} & Sp & $\mathrm{Sp}$ & 1091 & $\left\{\begin{array}{l}\text { Not-sp. . } \\
\text { S }\end{array}\right.$ & & & & & 1 & & 4 & 6 & 7 & 3 & 6 & 5 & & 32 \\
\hline & Sp & $\ddot{\mathrm{Sp}}$ & 1921 & Not-sp. & & & & & 1 & & 9 & $\begin{array}{l}8 \\
2\end{array}$ & 1 & 1 & 1 & 1 &. & 23 \\
\hline 2065 & 6 & & 1921 & $\{$ Sp..... & & & & & & & $\dot{2}$ & 1 & $\begin{array}{l}1 \\
2\end{array}$ & $\begin{array}{l}3 \\
1\end{array}$ & 6 & 3 & & $\begin{array}{r}15 \\
6\end{array}$ \\
\hline \multirow{2}{*}{2175} & $\mathrm{Sp}$ & $\mathrm{Sp}$ & & Not-sp.. & & & . & & & & & 2 & 4 & 4 & 17 & 18 & . & 45 \\
\hline & 5 & .... & 2023 & Sp. & & & & & & & 12. & 7 & 8. & & 2 & 3 & & 32 \\
\hline \multirow[t]{2}{*}{$2091^{2}$} & 6 & & 1921 & $\{$ Not-sp... & & & & & & & 9 & 5. & 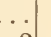 & 8 & 6 & 2 & & 30 \\
\hline & $\begin{array}{r}\text { Sp } \\
6\end{array}$ & Sp & 1921 & Sp.............. & & & & 1 . & & & 4 & $\begin{array}{l}4 \\
2\end{array}$ & 2 & 2 & \begin{tabular}{l|l}
3 & \\
5
\end{tabular} & $\ddot{4}$ & & 16 \\
\hline \multirow{2}{*}{$2143^{2}$} & $\mathrm{Sp}$ & $\mathrm{sp}$ & & $\left\{\begin{array}{l}\mathrm{s} \\
\mathrm{s} . \ldots \ldots\end{array}\right.$ & & & & & & & 3 & 5 & $\begin{array}{l}\mathrm{b} \\
2\end{array}$ & $\begin{array}{l}1 \\
5\end{array}$ & $\begin{array}{l}5 \\
3\end{array}$. & 4 & & $\begin{array}{l}20 \\
18\end{array}$ \\
\hline & & & & Not-sp not-ro & & & & & & & 4. & 2 & 1 & 4 & 2 & 3 & & 16 \\
\hline \multirow[t]{3}{*}{2245} & 6 & & 2065 & Not-sp ro ... & & & & & & & 5 & 2 & 2 & 3 & 5 & 2 & & 19 \\
\hline & Sp ro & 1331 & 2127 & Sp not-ro. & & & & & & & 4 & 4.). & $\therefore$ & 2 . & .1 & 3 & & 13 \\
\hline & & & & & & & & & & & 9 & 3 & 7 & 4 & 2 & $1 \mid$ & & 27 \\
\hline
\end{tabular}

${ }^{1}$ In tables 37 and 38 the upper row in the parent columns refers to the mother of the culture in question; the lower row to the father.

${ }^{2} 2091$ and 2143 are two broots from the same parents. 
Table 38.-Tests for Modifying Factors.

864. Inbred Plus Line.

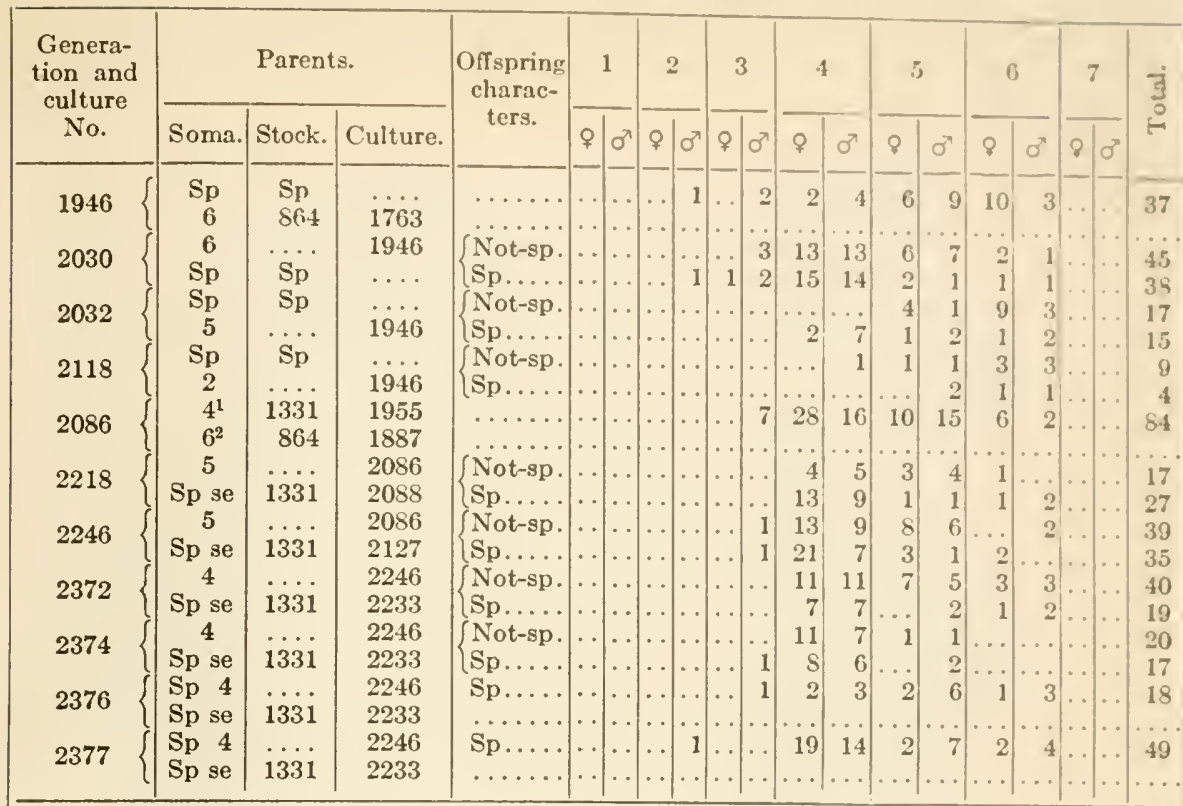

Crossbred Plus Line.

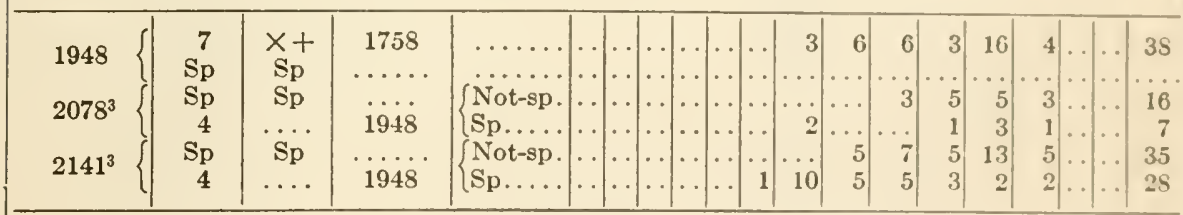

Crossbred Minus Line.

\begin{tabular}{|c|c|c|c|c|c|c|c|c|c|c|c|c|c|c|c|c|c|}
\hline 2201 & $\underset{2}{S p}$ & $\begin{array}{l}S p \\
\times-\end{array}$ & 2051 & & & & & & & & 1 & 2 & 1 & 3 & 3 & & 10 \\
\hline & 5 & & 2201 & Sot-sp. & & & & & 1 & 2 & & 11 & 2 & 5 & 6 & & 27 \\
\hline 2382 & Sp ro & 1331 & 2182 & Sp.. & • & & & & & 3 & 2 & 2 & 2 & 2 & & & 11 \\
\hline 2131 & $\begin{array}{r}4 \\
\mathrm{Sp}\end{array}$ & ${ }_{\mathrm{Sp}}$ & 2015 & & & & & & & 1 & 5 & 4 & 7 & 2 & 1 & & 20 \\
\hline 2259 & Sp & Sp & & Not-sp. & & & & & & 2 & & 9 & 3 & 5 & i & & 23 \\
\hline 2209 & 4 & $\cdots$ & 2131 & & & & & & & 2 & 6 & 3 & 7 & 2 & 1 & & 21 \\
\hline 2378 & 5 & ת & 2259 & $\{$ Not-sp. & & & & & & 9 & 5 & 4 & 1 & . & 1 & & 20 \\
\hline & $\begin{array}{c}\mathrm{Sp} \\
\mathrm{Sp} 5\end{array}$ & Sp & 2259 & Sp.. & & & & & ? & $\begin{array}{r}9 \\
19\end{array}$ & $\begin{array}{l}2 \\
8\end{array}$ & $\begin{array}{l}3 \\
3 \\
3\end{array}$ & 3 & $\frac{2}{2}$ & 1 & & 23 \\
\hline 2394 & Sp ro & 1331 & 2233 & Ro & & & & & 2 & 13 & 7 & 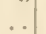 & 4 & & 3 & & 29 \\
\hline & 5 & & 2259 & Sot-sp. & & & & & & 6 & 3 & 1 & 2 & & 1 & & 13 \\
\hline 2395 & Sp ro & 1331 & 2233 & Sp. & & & & & 1 & 11 & 11 & & 1 & & 1 & & 25 \\
\hline 239 & 5 & & 2259 & Not-sp. & & & & & & 4 & 5 & 3 & 3. & & 3 & & is \\
\hline & Sp ro & 1331 & 2233 & Sp.... & & & • & & & 5 & 10 & 1. & 3 & & 1 & & 20 \\
\hline 2397 & 5 & & 2259 & $\{$ Not-sp. & & & & & 2 & 12 & 4 & 1 & & .. & 1 & & 20 \\
\hline & sp ro & 1331 & 2233 & (sp. & & & 1 & & & 1.0 & 10 & & & & 1 & & 25 \\
\hline
\end{tabular}

${ }^{1}$ sp se ro.

${ }^{2}$ ro. 
1002. Inbred Plus Line.

\begin{tabular}{|c|c|c|c|c|c|c|c|c|c|c|c|c|c|c|c|c|c|c|c|}
\hline \multirow{2}{*}{$\begin{array}{l}\text { Genera- } \\
\text { tion and } \\
\text { culture } \\
\text { No. }\end{array}$} & \multicolumn{3}{|c|}{ Parents. } & \multirow{2}{*}{$\begin{array}{l}\text { Offspring } \\
\text { icharacters. }\end{array}$} & \multicolumn{2}{|c|}{1} & 2 & \multicolumn{2}{|c|}{3} & \multicolumn{2}{|l|}{4} & \multicolumn{2}{|l|}{5} & \multicolumn{2}{|l|}{6} & \multicolumn{2}{|l|}{7} & 8 & \multirow{2}{*}{ 葋 } \\
\hline & Soma. & Stock. & Culture. & & 우 & $\sigma^{7}$ & १ & ๆ & $0^{7}$ & † & $\sigma^{7}$ & 우 & $\sigma^{\pi}$ & \% & $\sigma^{2}$ & $\% 0^{\circ}$ & & $\sigma^{7}$ & \\
\hline 2025 & $\begin{array}{r}6 \\
\text { Sp ro }\end{array}$ & $\begin{array}{l}1002 \\
1331\end{array}$ & $\begin{array}{l}1924 \\
1906\end{array}$ & & & & & & - & 14 & 7 & 10 & 7 & 2 & 10 . & & & & 50 \\
\hline 2153 & Sp ro & 1331 & 2009 & $\{$ Not-sp. & & & & & 1 & 1 & 4 & 6 & 10 & 4 & 7 . & & & & $\dddot{33}$ \\
\hline 2103 & 6 & $\cdots$ & $\begin{array}{l}2025 \\
2025\end{array}$ & $\begin{array}{l}\text { Sp......... } \\
\text { INot-sp.... }\end{array}$ & & & & & $\because$ & 9 & 8 & 9 & 8 & 5 & 1 . & & & & 40 \\
\hline 2150 & $\begin{array}{l}5 \\
\text { Sp }\end{array}$ & 1331 & 1978 & $\left\{\begin{array}{l}\text { Sp.. } \\
\text { Sp. }\end{array}\right.$ & & & & & i & 12 & $\begin{array}{r}5 \\
13\end{array}$. & $\begin{array}{c}2 \\
. .\end{array}$ & $\begin{array}{l}5 \\
1\end{array}$. & $\begin{array}{l}2 \\
. .\end{array}$ & \begin{tabular}{c|c}
2 & . \\
$\ldots$ & .
\end{tabular} & & & & $\begin{array}{l}23 \\
27\end{array}$ \\
\hline & & & 2153 & $\left\{\begin{array}{l}\text { Not-s } \\
\text { Not-s }\end{array}\right.$ & & & & & t & $\begin{array}{l}7 \\
3\end{array}$ & $\begin{array}{l}8 \\
5\end{array}$ & $\begin{array}{l}6 \\
2\end{array}$ & $\begin{array}{l}5 \\
1\end{array}$ & $\begin{array}{l}1 \\
1\end{array}$ & $\begin{array}{l}3 . \\
1\end{array}$ & & & & 30 \\
\hline 2333 & Sp ro & 1331 & 2182 & Sp no & & & & & & 5 & 6 & 5 & 2 & 2 & 6 . & & & & $\begin{array}{l}13 \\
26\end{array}$ \\
\hline & & & & (Sp ro....... & & & & & & 4 & 6 & 3 & 2 & 1 & 2 . & & & & 18 \\
\hline 2433 & $\begin{array}{c}6 \\
2 \mathrm{sp} \mathrm{ro}\end{array}$ & $\begin{array}{l}1002 \\
1331\end{array}$ & $\begin{array}{l}2415 \\
2414 \text {. }\end{array}$ & & & & & & . & 2 & 3 & 12 & 11 & 22 & 25 & 1 & & & 76 \\
\hline 2471 & Sp ro & 1331 & 2431 & $\{$ Not-sp & & & & & & 3 & 5 & 9 & 7 & & $\ddot{3} \mid$ & & & & 27 \\
\hline 2471 & 6 & $\cdots$ & 2433 & isp.. & & & & & 2 & 8 & 10 & 2 & 1 & & & & & & 24 \\
\hline 2481 & 5 & & 2433 & $\left\{\begin{array}{l}\text { Not-sp } 1 . \\
\text {. }\end{array}\right.$ & & 1 & . & & 4 & 4 & 6 & 8 & 6 & 5 & 2 . & & & & 140 \\
\hline 2401 & $\mathrm{Sp}$ & Sp & & Sp. & & & & & 2 & 4 & 4 & 3 & 6 & 10 & 4. & & & & 33 \\
\hline 2488 & 6 & & 24 & $\left\{\begin{array}{l}\text { Not- } \\
\mathrm{Sp}^{1}\end{array}\right.$ & & 1 & & & 4 & 12 & 3. & 2 & 7 & 14 & 5. . & & & & 49 \\
\hline & $\begin{array}{c}\text { Sp ro } \\
5\end{array}$ & 1331 & $\begin{array}{l}2432 \\
2471\end{array}$ & Not-sp. & & 1 & & & 1 & 10 & 8 & 3 & 4 & 2 & 1 . & & & & 138 \\
\hline 2516 & Sp ro & 1331 & 2432 & $\{\mathrm{Sp} \ldots \ldots$ & & $\because$ & . & 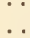 & 1 & $\begin{array}{l}16 \\
15\end{array}$ & $\begin{array}{r}13 \\
5\end{array}$ & $\begin{array}{l}3 \\
4\end{array}$ & $\begin{array}{r}12 \\
5\end{array}$ & $\begin{array}{l}2 \\
1\end{array}$. & 1. & & & & $\begin{array}{l}47 \\
31\end{array}$ \\
\hline 2436 & Sp se & 1331 & 2414 & - & & $\cdots$ & . & .. & 2 & 15 & 10 & 11 & 14 & 4 & 4 & 1 & & & 61 \\
\hline & 6 & 1002 & 2415 & & & & & & & . & . & & & & & & & & \\
\hline 2480 & Sp & $\mathrm{Sp}$ & 2436 & $\left\{\begin{array}{l}\text { Not } \\
\text { Sn }\end{array}\right.$ & & .. & & & . & $\cdots$ & $\cdots$ & $\because$. & $\cdots$ & 9 & 10 & 2 & & & 21 \\
\hline $2475^{1}$ & 4 & $\cdots$ & 2436 & No & & & & & & $\cdots$ & i) & $1]^{\circ}$ & $\ddot{2}$ & 3 & $\ddot{6} \cdot$. & & & & $\begin{array}{r}8 \\
14\end{array}$ \\
\hline & Sp & $\mathrm{Sp}$ & & $\{\mathrm{Sp}$. & & & & & . & 4 & 1 & 6 & 1 & 5 & 1 . & & & & 17 \\
\hline $2513^{1}$ & 4 & & 2436 & $\left\{\begin{array}{l}\text { Not-s } \\
\text { and }\end{array}\right.$ & & & & & & 1 & 2 & 4 & 4 & 9 & 15 . & & & & 35 \\
\hline & $\mathrm{Sp}$ & Sp & & isp. & & & & & . & 3 & 4 . & 2 & 1 & 13 & 14 . & & & & 37 \\
\hline 2476 & 5 & & 2436 & $\left\{\begin{array}{l}\text { Not-sp } \\
\text { f }\end{array}\right.$ & & & & & & & & & : & 8 & 12 & 1 & 1 & & 22 \\
\hline & Sp & $\mathrm{Sp}$ & & & & & & & & $\because 1$ & 1 & & 4 & 9 & 7 . & & & & 21 \\
\hline 2519 & $\begin{array}{c}5 \\
S p\end{array}$ & $\because \ddot{\mathrm{S}}$ & 2436 & $\left\{\begin{array}{l}\text { Not-sp... } \\
\text { Sn }\end{array}\right.$ & . & . & & & . & 2 & 1 & 2 & 1 & 15 & 14 . & & & & 35 \\
\hline 2607 & $\begin{array}{l}\text { Sp } \\
\text { Sp }\end{array}$ & $\begin{array}{l}\text { Sp } \\
\text { Sp }\end{array}$ & $\cdots$ & (sp. & & - & & & $\left|\begin{array}{l}i \\
i\end{array}\right|$ & 3 & $\begin{array}{l}1 \\
3\end{array}$ & (4) & ${ }^{6}$ & 10 & 8. & & & & 28 \\
\hline 2607 & 6 & 1002 & 2548 & & & & & & & & & 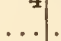 & 2 & 18 & 10. & & & & 39 \\
\hline 2669 & $\mathrm{Sp}$ & Sp & & Not-sp. & & & & & & & & 2 & 2 & 13 & 16 & 1 & & & 34 \\
\hline & 5 & $c$ & 2607 & Sp. & . & . & & & . & 1 & 2 & 4 & 4 & 9 & 8. & & & & 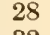 \\
\hline 2698 & $\begin{array}{l}\text { Sp } \\
6\end{array}$ & Sp & 2607 & & - & - & & • & $\cdots$ & $\cdots$ & 1 . & I & $\therefore$ & 13 & 17 & 1 & & & 32 \\
\hline 2699 & $\begin{array}{l}\text { O } \\
\text { Sp }\end{array}$ & $\ddot{\mathrm{Sp}}$ & 2608 & $\int \begin{array}{l}\mathrm{spp} \\
\mathrm{No}\end{array}$ & & . & & & & & . & 2 & 3 & $\begin{array}{r}15 \\
3\end{array}$ & 12 . & . & & & 32 \\
\hline 2099 & 6 & & 2607 & & 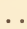 & 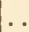 & . & & & 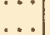 & .. & 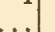 & 4 & 14 & 7 & . & & & 25 \\
\hline 2711 & $\mathrm{Sp}$ & Sp & & & . & . & & & & & & $\ldots$ & 1 & 10 & 15 & 1 & & & 7 \\
\hline & 6 & $\ldots$ & 2607 & & . & . & . & & . & 1 & & .. & 3 & 12 & 9 . & . & & & 25 \\
\hline 2682 & 6 & & 2607 & $\int$ Not-sp. & .. & . . & .. & & & & 3 & 3 & 7 & 10 & 12 . & & & & 35 \\
\hline & Sp & Sp & & & & & & & & 2 & 3 & 2 & 어 & 7 & 7 & 1 & & & 28 \\
\hline & & & & not-ro. & & . & {$[-5+2+3$} & & 1 & 6 & 6 & 1 & 4 & 2 & 2 & & . & & 23 \\
\hline 2665 & $\begin{array}{r}5 \\
\operatorname{sn} r\end{array}$ & 1331 & 2607 & $\left\{\begin{array}{l}\text { Not- } \\
\mathrm{Sp} \text { r }\end{array}\right.$ & $\cdot$ & . & . & 1 & $1 \mid \begin{array}{l}2 \\
4\end{array}$ & $\begin{array}{l}6 \\
6\end{array}$ & $\begin{array}{l}3 \\
6\end{array}$ & 7 & 5 & 3 & 2 & & . & & 29 \\
\hline & Sp ro & 1331 & & Sp & & $\cdots$ & & i & $\begin{array}{l}4 \\
1\end{array}$ & $\begin{array}{l}0 \\
3\end{array}$ & $\begin{array}{l}0 \\
7 .\end{array}$ & 7 & 5 & 6 & 2 & & & & $\begin{array}{l}19 \\
32\end{array}$ \\
\hline $2789^{2}$ & Sp 5 & & 266 & Ssp not-ro & & . & . & .. & 1 & 1 & 6 & 5 & 3 & 2 & 3 . & & & & 21 \\
\hline & Spro & 1331 & 26 & & & 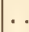 & . & 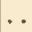 & & 8 & 5 & 5 & 11 & 14 & 6 . & & & & 49 \\
\hline $2803^{2}$ & Sp 5 & & 2711 & 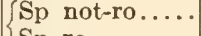 & . & . & . & .. & & 2 & 1 & 1 & 4 & 4 & 1 . & & & & 13 \\
\hline & Sp ro & 1331 & 2663 & isp ro.... & & & & .. & & $\ldots$ & 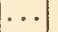 & 1 & 4 & 8 & 2 & 1 & & & 16 \\
\hline 2633 & Sp & $\begin{array}{c}\mathrm{Sp} \\
1002\end{array}$ & & $\cdots$ & & & & & & & .. & 1 & 2 & 6 & 3 & & & & 12 \\
\hline & Sp ro & 1331 & 26 & \{Not & & & & & &. & .. & 2 & 1 & 10 & 4 & & & & 17 \\
\hline 2690 & 5 & & 2633 & & & & & & & $\cdots$ & 1 & 2 & 4 & 6 & & & & & 10 \\
\hline 2704 & Sp & Sp & & $\{$ Not- & & & & & & $\ldots$ & 2 & 2 . & .. & 9 & 8 & & 1 . & & 22 \\
\hline & 6 & & 2633 & & & & & & & $\cdots$ & 1 & 3 . & & 6 & 3 & & & & 13 \\
\hline & & & & (Not-sp not-ro. & & & & & & & 5 & 1 & 1 & 6 & 4 & & & & 18 \\
\hline 2811 & $\begin{array}{c}5 \\
S n r o\end{array}$ & 1331 & 2704 & Not-sp rc & & & & & & $\begin{array}{l}5 \\
3\end{array}$ & 1 & 6 & 10 & 4 & 7. & & 1 & & $\begin{array}{l}34 \\
15\end{array}$ \\
\hline & & & 2063 & $\mid \begin{array}{l}S p \text { not-1 } \\
\text { Sp ro... }\end{array}$ & & & & & & 2 & 1 & 2 & $\begin{array}{l}3 \\
8\end{array}$ & $\begin{array}{l}5 \\
1\end{array}$ & 10 & & & & 23 \\
\hline
\end{tabular}

${ }^{1} 2475$ and 2518 are $i w a$ biouds froir sulue parents. . 2799 and 2803 had the same male parent. 



\section{North Carolina State University Libraries}

OH371.S8

ANALYSIS OF THE EFFECTS OF SELECTION

IIII

S02776111 A 